Argonne

ANL/EVS/AGEM/TR-09-09

\title{
March-June 2009 Monitoring Results for Barnes, Kansas
}

\author{
Environmental Science Division
}


About Argonne National Laboratory

Argonne is a U.S. Department of Energy laboratory managed by UChicago Argonne, LLC under contract DE-AC02-06CH11357. The Laboratory's main facility is outside Chicago, at 9700 South Cass Avenue, Argonne, Illinois 60439. For information about Argonne and its pioneering science and technology programs, see www.anl.gov.

\section{Availability of This Report}

This report is available, at no cost, at http://www.osti.gov/bridge. It is also available on paper to the U.S. Department of Energy and its contractors, for a processing fee, from:

U.S. Department of Energy

Office of Scientific and Technical Information

P.O. Box 62

Oak Ridge, TN 37831-0062

phone (865) 576-8401

fax (865) 576-5728

reports@adonis.osti.gov

\section{Disclaimer}

This report was prepared as an account of work sponsored by an agency of the United States Government. Reference herein to any specific commercial product, process, or service by trade name, trademark, manufacturer, or otherwise, does not necessarily constitute or imply its endorsement, recommendation, or favoring by the United States Government or any agency thereof. The views and opinions of document authors expressed herein do not necessarily state or reflect those of the United States Government or any agency thereof, Argonne National Laboratory, or UChicago Argonne, LLC. 


\section{March-June 2009 Monitoring Results for Barnes, Kansas}

by

Applied Geosciences and Environmental Management Section

Environmental Science Division, Argonne National Laboratory

September 2009

USDA 


\section{Contents}

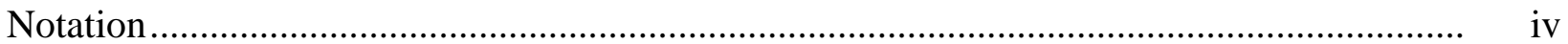

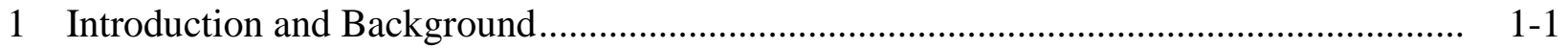

2 Conceptual Site Model ................................................................................... $2-1$

3 Sampling and Analysis Activities ................................................................. $3-1$

3.1 Measurement of Groundwater Levels ............................................................

3.2 Well Sampling and Analyses .................................................................. $3-2$

3.3 Handling and Disposal of Investigation-Derived Waste .......................................... 3-4

3.4 Quality Control for Sample Collection, Handling, and Analysis........................... 3-4

4 Results and Discussion.....................................................................................

4.1 Groundwater Level Data ................................................................................ 4-1

4.2 Analytical Results for Volatile Organic Compounds in Groundwater Samples and Lateral Distribution of the Contaminants ....................................................... 4-3

5 Conclusions, Ongoing Tasks, and Recommendations .......................................... $5-1$

5.1 Conclusions ............................................................................................. 5

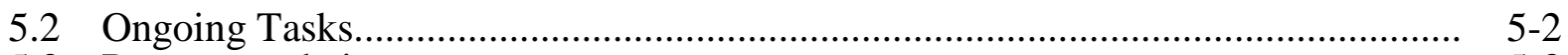

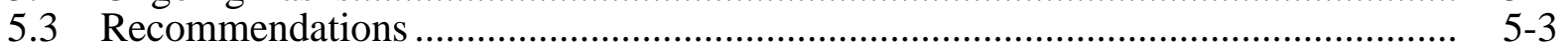

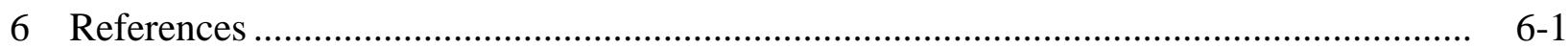

Appendix A: Sampling Activities and Field Measurements at Barnes in March

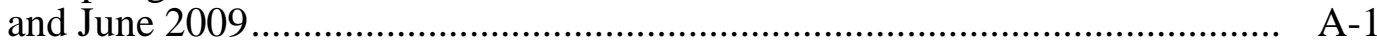

Appendix B: Results from the AGEM Laboratory for Dual Analyses of Samples Collected at Barnes in March and June 2009 and for Quality Control Samples

Appendix C: Sample Documentation from TestAmerica Laboratories, Inc.

\section{Figures}

1.1 Groundwater sampling locations at Barnes in March and June 2009..................... 1-2

3.1 Wells at Barnes equipped with data loggers for automatic water level monitoring .... 3-6

4.1a Potentiometric surface map depicting the groundwater flow direction in the deeper aquifer zone at Barnes under static conditions on February 11, 2009 


\section{Figures (Cont.)}

4.1b Potentiometric surface map depicting the groundwater flow direction in the deeper aquifer zone at Barnes under static conditions on May 21, 2009

4.2a Hydrographs summarizing monthly results of long-term water level monitoring in the deep-zone wells at Barnes, November 2008 to May 2009.

4.2b Hydrographs summarizing monthly results of long-term water level monitoring in the intermediate-zone wells at Barnes, November 2008 to May 2009

4.3 Analytical results for carbon tetrachloride in groundwater samples collected at Barnes in July 2008 to June 2009.

4.4 Analytical results for chloroform in groundwater samples collected at Barnes in July 2008 to June 2009 .

4.5 Interpreted carbon tetrachloride plume in March 2009 in wells screened in the intermediate aquifer zone

4.6 Interpreted carbon tetrachloride plume in March 2009 in wells screened in the deep aquifer zone

\section{Tables}

4.1 Hand-measured water levels at Barnes, October 2008-May 2009

4.2 Elevation ranges measured for the three aquifer zones, June 2007-July 2009

4.3 Analytical results from the AGEM Laboratory for volatile organic compounds in groundwater samples collected at Barnes, July 2006 to June 2009

A.1 Sequence of sampling activities at Barnes in March and June 2009

A.2 Field measurements for groundwater samples collected at Barnes, July 2006 to June 2009

B.1 Analytical results for samples and replicates collected at Barnes in March and June 2009 and for quality control samples 


\section{Notation}

AGEM Applied Geosciences and Environmental Management

AMSL above mean sea level

BGL below ground level

${ }^{\circ} \mathrm{C} \quad$ degree(s) Celsius

CCC Commodity Credit Corporation

COC chain of custody

DO dissolved oxygen

EPA U.S. Environmental Protection Agency

$\mathrm{ft} \quad$ foot (feet)

gal gallon(s)

$\mathrm{hr} \quad$ hour(s)

in. $\quad$ inch(es)

KDHE Kansas Department of Health and Environment

L liter(s)

$\mu \mathrm{g} / \mathrm{kg} \quad$ microgram(s) per kilogram

$\mu \mathrm{g} / \mathrm{L} \quad$ microgram(s) per liter

$\mu \mathrm{S} / \mathrm{cm}$ microsiemen(s) per centimeter

$\mathrm{mg} / \mathrm{L} \quad$ milligram(s) per liter

min minute

$\mathrm{mV} \quad$ millivolt(s)

ORP oxidation-reduction potential

PWS public water supply

RBSL risk-based screening level

USDA U.S. Department of Agriculture

VOC volatile organic compound 


\section{March and June 2009 Monitoring Results for Barnes, Kansas}

\section{Introduction and Background}

The Commodity Credit Corporation of the U.S. Department of Agriculture (CCC/USDA) operated a grain storage facility at Barnes, Kansas, during most of the interval 1949-1974. Carbon tetrachloride contamination was initially detected in 1986 in the town's public water supply wells. In 2006-2007, the CCC/USDA conducted a comprehensive targeted investigation at and near its former property in Barnes to characterize this contamination. Those results were reported previously (Argonne 2008a).

In November 2007, the CCC/USDA began quarterly groundwater monitoring at Barnes. The monitoring is being conducted on behalf of the CCC/USDA by Argonne National Laboratory, in accord with the recommendations made in the report for the 2006-2007 targeted investigation (Argonne 2008a). The objective is to monitor the carbon tetrachloride contamination identified in the groundwater at Barnes. The sampling is presently conducted in a network of 28 individual monitoring wells (at 19 distinct locations), 2 public water supply wells, and 1 private well (Figure 1.1).

The results of the 2006-2007 targeted investigation and the subsequent monitoring events (Argonne 2008a-d, 2009) demonstrated the presence of carbon tetrachloride contamination in groundwater at levels exceeding the Kansas Department of Health and Environment (KDHE) Tier 2 risk-based screening level (RBSL) of $5.0 \mu \mathrm{g} / \mathrm{L}$ for this compound. The contaminant plume appears to extend from the former CCC/USDA property northwestward, toward the Barnes public water supply wells. Information obtained during the 2006-2007 investigation indicates that at least one other potential source might have contributed to the groundwater contaminant plume (Argonne 2008a). The former agriculture building owned by the local school district, located immediately east of well PWS3, is also a potential source of the contamination.

This current report presents the results of the fifth and sixth quarterly monitoring events, conducted in March and June 2009. During these two monitoring events, low-flow sampling methods were used to purge and sample all wells. These were the fourth and fifth events at Barnes during which the low-flow sampling method was used. 


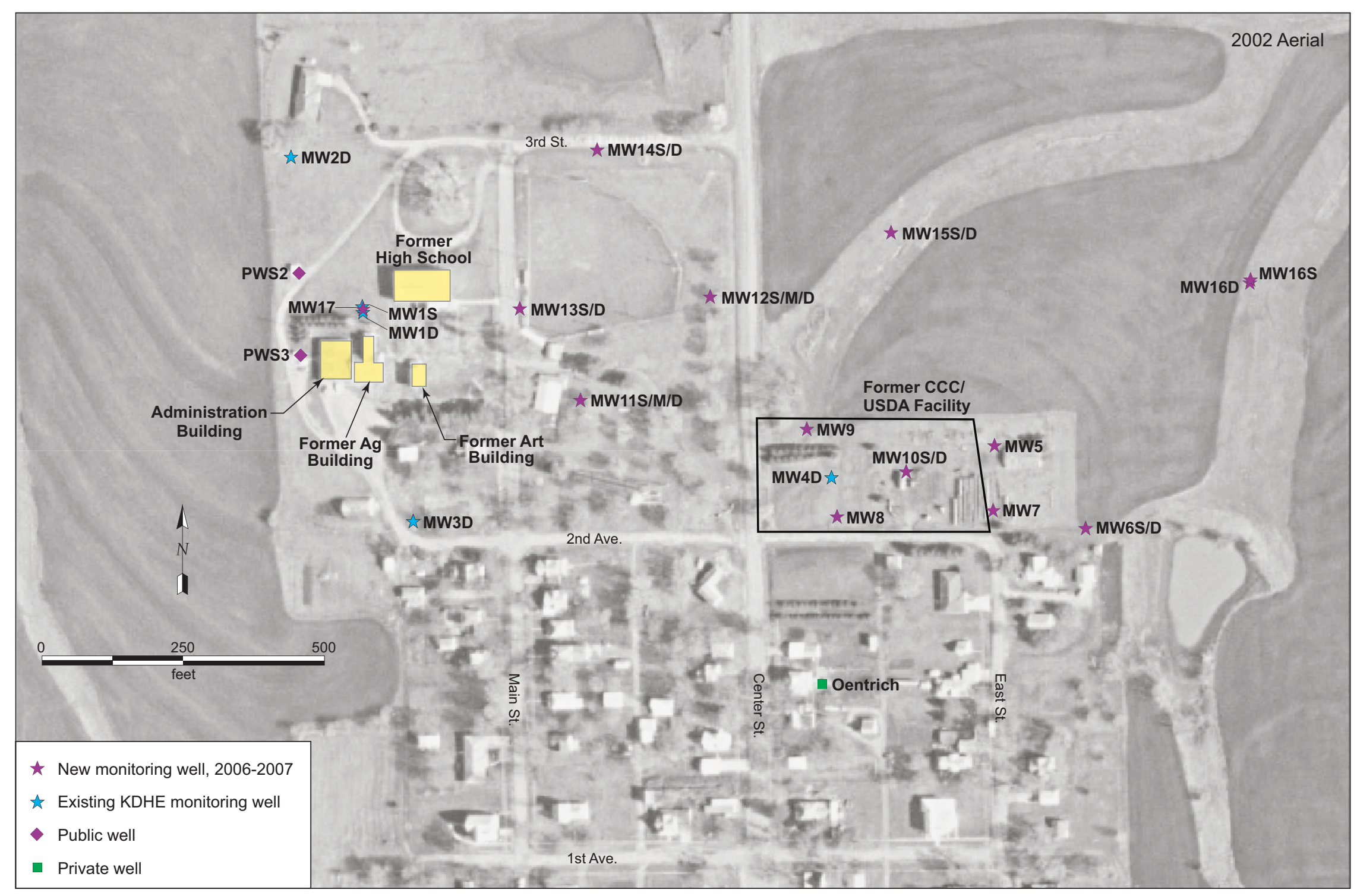

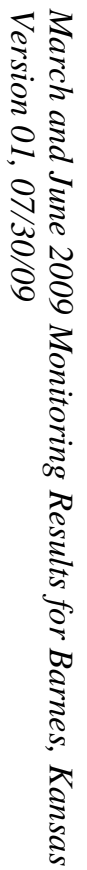

FIGURE 1.1 Groundwater sampling locations at Barnes in March and June 2009. Source of photograph: NAPP (2002). 


\section{Conceptual Site Model}

Barnes lies in a transition zone between the Flint Hills and the glaciated region. The area's topography consists of gently sloping hills of Pleistocene loess (with variations in elevation < $50 \mathrm{ft}$ ) overlying a shale unit and interbedded shale, limestone, and siltstone of the Permian Chase Group. Groundwater for the public water supply is produced from the bedrock aquifer of the Chase Group.

The site lithology and subsurface contaminant conditions were determined in the 20062007 investigation through the collection of continuous core samples at 13 locations (MW5MW17) extending from east of the former CCC/USDA grain storage facility and westward, across the area of concern, toward the public water supply wells (Argonne 20008a). The predominant lithology consists of a thin layer of silty clay to clayey silt with fine sand in the upper 2-20 ft. This layer is underlain by highly weathered shale interbedded with thin layers of fractured limestone at depths of approximately 18-132 ft BGL (below ground level). No soil contamination at concentrations above the RBSL of $200 \mu \mathrm{g} / \mathrm{kg}$ for the soil-to-groundwater protection pathway was detected at any of the 13 locations. Trace concentrations $(<10 \mu \mathrm{g} / \mathrm{kg})$ of carbon tetrachloride were detected in soil at 3 locations on the former CCC/USDA facility property. These low concentrations would not result in higher concentrations in groundwater, and therefore the soil on the former CCC/USDA property is not considered to be an ongoing significant source for the carbon tetrachloride contamination in groundwater.

Groundwater is present predominantly in the fractured limestone layers. Monitoring wells were installed and screened at various depths, with several locations completed as nested wells to determine contaminant concentrations at depths where water-bearing zones were indicated. Throughout the monitoring program, a detailed evaluation of the hand-measured water levels and carbon tetrachloride data has been conducted to investigate the stratigraphy of the saturated zone. The accumulated water level data suggest that at least three vertically distinct aquifer zones are present: shallow, intermediate, and deep. These zones are discussed further in Section 4.1. The vertical distribution of the carbon tetrachloride in groundwater indicates that the highest concentrations occur in the intermediate aquifer zone (approximately 50-70 $\mu \mathrm{g} / \mathrm{L}$ over the course of the monitoring program to date). Lower concentrations have been detected in the deep aquifer zone, and no carbon tetrachloride has been detected in the shallow zone. Trace levels of carbon tetrachloride have been detected periodically in the two public water supply wells; these wells are believed to be screened over all three aquifer zones. 
Extensive documentation of the potentiometric surface at Barnes during the targeted investigation and subsequent monitoring events (Argonne 2008a-d, 2009) has indicated that operation of the public water supply wells strongly influences the groundwater flow direction. The accumulated data document a predominant direction of groundwater flow to the northeast under non-pumping conditions. In contrast, flow is toward the northwest, in the approximate direction of the public water supply wells, when pumping is occurring. The data demonstrate that the public water supply wells are operated daily, with drawdowns of as much as $2.25 \mathrm{ft}$ during pumping. Pumping and subsequent water level recovery periods typically range from $3 \mathrm{hr}$ to $7 \mathrm{hr}$ in duration, resulting in groundwater levels (and apparent flow directions) that shift relatively continuously throughout much of each day. For this reason, water level data collected by the automatic recorders, which are coincident in time at all monitored locations, provide the primary basis for determination of the topology of the potentiometric surface at any point in the cycles of groundwater pumping and recovery.

The automatic recorder data also provide critical information needed to evaluate the hydrologic regime in anticipation of a corrective action study. The accumulated data prior to November 2008 for recorders installed in deep-zone wells indicated the presence of both vertical and lateral influences on the local hydraulic gradients. In November 2008, intermediate-zone wells were equipped with automatic water level recorders to obtain detailed data on the potential temporal variability of the hydraulic heads in this aquifer zone. 


\section{Sampling and Analysis Activities}

\subsection{Measurement of Groundwater Levels}

The groundwater sampling events at Barnes on March 4-5 and June 16-19, 2009, involved 28 monitoring wells (MW1S, MW1D, MW2D, MW3D, MW4D, MW5, MW6S, MW6D, MW7, MW8, MW9, MW10S, MW10D, MW11S, MW11M, MW11D, MW12S, MW12M, MW12D, MW13S, MW13D, MW14S, MW14D, MW15S, MW15D, MW16S, MW16D, MW17). All of the well locations are shown in Figure 1.1. A chronological summary of the field activities is in Appendix A, Table A.1.

Before implementation of the low-flow sampling described in Section 3.2, a hand-held water level indicator was used to measure the depth to groundwater and the total depth of each well, to within $0.01 \mathrm{ft}$, from the top of the well casing. During the March 2009 event, monitoring wells MW1S and MW12S were measured but were found to be dry and consequently could not be sampled. During the June 2009 event, however, water was present at the base of monitoring well MW12S $(<1 \mathrm{ft}$ ), and a sample was collected. Two public water supply wells (PWS2 and PWS3) and one private well (Oentrich) were sampled but could not be measured because of well construction issues.

In addition to the manual water level measurements, data recorders have been gathering long-term data on the groundwater elevation and gradient at selected monitoring wells across the investigation area since 2006. The data loggers record water levels continuously at 60-min intervals. To augment the data generated by recorders installed in the deeper aquifer zone, in November 2008 water level recorders were installed in five wells - MW10S, MW11M, MW12M, MW13S, and MW17 — to investigate the potential hydraulic influences on groundwater flow and contaminant migration in the intermediate aquifer zone, in which the highest concentrations of carbon tetrachloride in groundwater have been identified. At present, a total of 14 wells are being monitored for water levels, at the locations shown in Figure 3.1.

The hand-measured and automatically recorded groundwater level data are presented and discussed in Section 4.1. 


\subsection{Well Sampling and Analyses}

After measurement of water levels, low-flow groundwater sampling techniques, according to U.S. Environmental Protection Agency (EPA) guidelines (Puls and Barcelona 1996; Yeskis and Zavala 2002), were used to purge and sample the monitoring wells. The Oentrich well and the public water supply wells were sampled at their respective faucets after purging for 5-10 min (Table A.1 in Appendix A). During both sampling events in March and June 2009, the public water supply well PWS2 had been in operation prior to sampling. For public wells PWS2 and PWS3, samples of untreated ("raw") produced water were collected at the wellheads prior to mixing and introduction into the public distribution system.

Under the exact requirements of K.A.R. 28-15, compliance samples would be collected from the distribution system after treatment and after water from the wells had been combined, as indicated in 40 CFR 141.24(f)(3). The sampling of individual wellheads at Barnes to test each well is a more stringent comparison with the Tier 2 standard of $5.0 \mu \mathrm{g} / \mathrm{L}$ than sampling of the blended water. In view of the additional margin of protection in this approach, the CCC/USDA has proposed to adhere to (and not exceed) the federal regulation's provision [141.24(f)(15)(i)] that "for systems which are conducting monitoring at a frequency greater than annual, compliance is determined by a running annual average of all samples taken at each sampling point."

The low-flow sampling of monitoring wells involved the use of a bladder pump and field measurement equipment designed to determine when representative formation water was entering the well screen (Puls and Barcelona 1996; Yeskis and Zavala 2002). Stabilization of formation water in the screened area of the well was determined by measuring the static water levels and monitoring the levels of $\mathrm{pH}$, temperature, specific conductivity, oxidation-reduction potential (ORP), and dissolved oxygen (DO) during pumping.

The following procedure was followed for each well sampled:

1. A bladder pump was inserted into the well to a depth midway between the top and bottom of the screen. To minimize disturbance of the solids that are typically present at the bottom of a well, care was taken not to lower the pump to the bottom of the casing. 
2. The pumping rate for the bladder pump was set to ensure that minimal drawdown occurred in each well during pumping. The rate was monitored by measuring the static water level periodically throughout pumping.

3. Polyethylene tubing was used to connect the bladder pump to an in-line flow cell. Formation parameters, including $\mathrm{pH}$, temperature, specific conductivity, ORP, and DO, were measured continuously in the in-line flow cell during pumping. Measurements were recorded every 4 min until three successive measurements for each parameter were within a range indicating that the formation water was stable. The range for formation stabilization varies for each parameter, as follows: $\mathrm{pH}$, within 0.1 ; temperature, within $3 \%$; specific conductivity, within $3 \%$; ORP, within $10 \mathrm{mV}$; and DO, within $10 \%$.

4. After stabilization of the formation water parameters occurred, the polyethylene tubing was disconnected from the in-line flow cell, and a representative groundwater sample was pumped through the tubing into laboratory-approved containers.

5. The polyethylene tubing for each well was kept and dedicated for reuse at that well. In addition, pumping rate data were recorded for each well as a reference for subsequent sampling events.

The sequence of activities during the March and June 2009 well sampling events is summarized in Appendix A, Table A.1. The field measurements are in Appendix A, Table A.2.

Groundwater samples designated for analyses for volatile organic compounds (VOCs) were collected in appropriate laboratory containers, labeled, packaged, and chilled to $4^{\circ} \mathrm{C}$ by placement in ice-filled coolers. The samples were shipped via an overnight delivery service to the Applied Geosciences and Environmental Management (AGEM) Laboratory at Argonne for VOCs analyses with EPA Method 524.2 (EPA 1995). Aliquots of selected samples (chosen in the field) were also shipped to TestAmerica Laboratories, Inc., South Burlington, Vermont, for verification VOCs analyses according to EPA Contract Laboratory Program protocols.

The analytical results are presented and discussed in Section 4.2. 


\subsection{Handling and Disposal of Investigation-Derived Waste}

Purge water generated as potentially contaminated investigation-derived waste was containerized on-site in 55-gal drums. The accumulated purge water (less than two drums) has been sampled for VOCs (including ethylene dibromide) and nitrates. The samples are being analyzed by a Kansas-certified laboratory, Pace Analytical Services (Lenexa, Kansas). If the analytical results indicate concentrations of carbon tetrachloride, chloroform, ethylene dibromide, and nitrate below the KDHE RBSL standards, the water will be discharged on-site per agreement with the KDHE.

\subsection{Quality Control for Sample Collection, Handling, and Analysis}

Quality assurance/quality control procedures followed during the March and June 2009 monitoring events are described in detail in the Master Work Plan (Argonne 2002). The results are summarized as follows:

- Sample collection and handling activities were monitored by the documentation of samples as they were collected and the use of chain-ofcustody forms and custody seals to ensure sample integrity during handling and shipment.

- Samples designated for VOCs analyses were received with custody seals intact and at the appropriate preservation temperature. All samples sent to the AGEM Laboratory were analyzed within the required holding times.

- Quality control samples collected to monitor sample-handling activities (trip blanks and an equipment rinsate) and method blanks analyzed with the samples to monitor analytical methodologies were all free of carbon tetrachloride and chloroform contamination.

- Groundwater samples were analyzed for VOCs at the AGEM Laboratory by the purge-and-trap method on a gas chromatograph-mass spectrometer system. Calibration checks analyzed with each sample delivery group were required to be within $\pm 20 \%$ of the standard. Surrogate standard determinations 
- performed on samples and blanks were within the specified range of 80-120\% for all samples, in either the initial analysis or a successful reanalysis.

- Results from the AGEM Laboratory for dual analyses of the groundwater samples are in Appendix B, Table B.1. The results of the dual analyses compare well, with average relative percent difference values for carbon tetrachloride and chloroform of approximately 5\% and 3\%, respectively, over the two monitoring events, indicating consistency in the sampling and analytical methodologies. Analytical results for quality control samples are also in Appendix B, Table B.1.

- In accordance with the procedures defined in the Master Work Plan (Argonne 2002), groundwater samples were submitted to a second laboratory (TestAmerica) for verification analysis according to the protocols of the EPA's Contract Laboratory Program. Documentation is in Appendix C. The results from the two laboratories compare favorably over the range of contaminant concentrations detected; average relative percent difference values for carbon tetrachloride and chloroform were approximately $13 \%$ and $10 \%$, respectively, over the two monitoring events, for samples in which contamination was detected. 


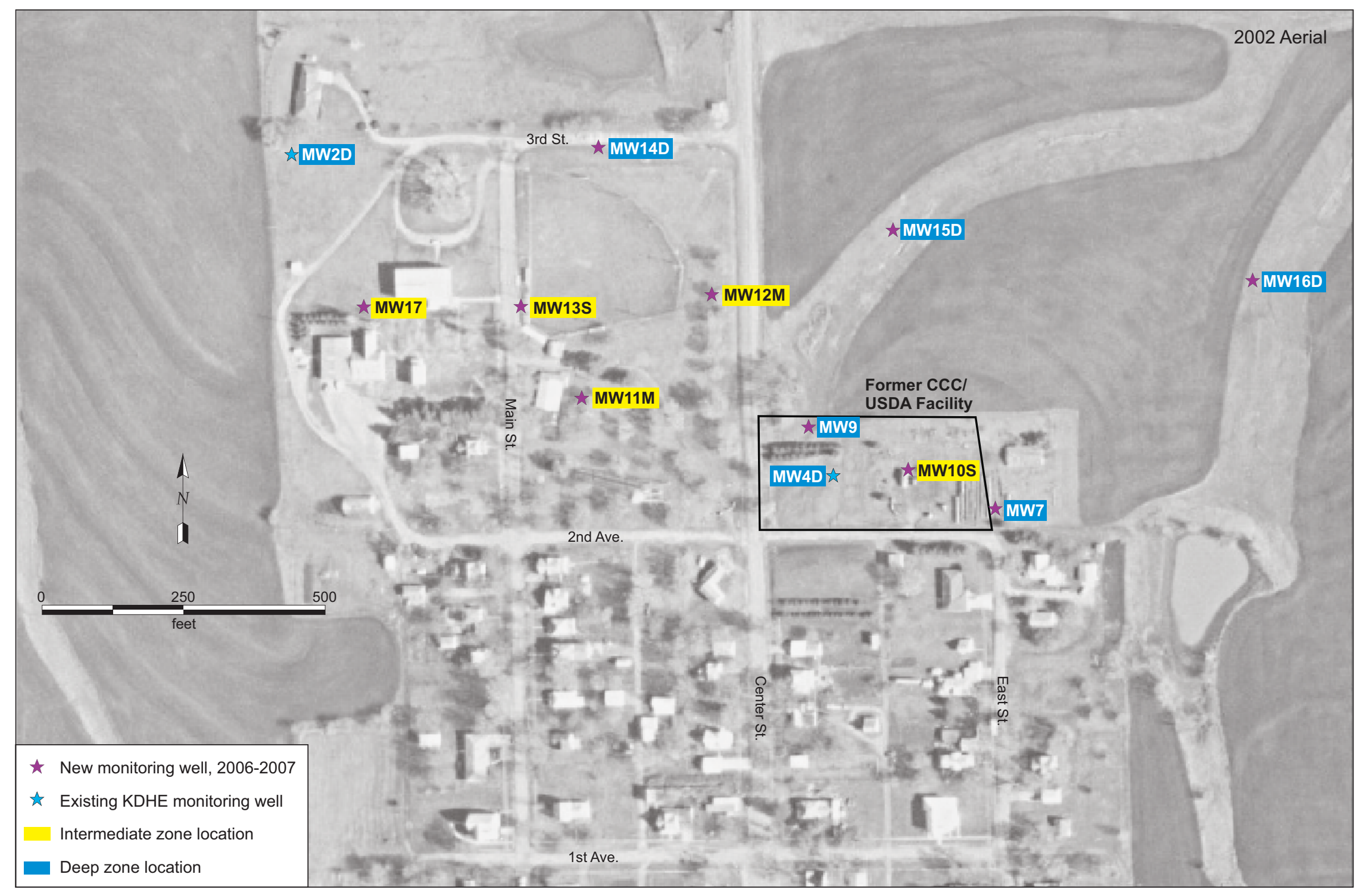

FIGURE 3.1 Wells at Barnes equipped with data loggers for automatic water level monitoring. Source of photograph: NAPP (2002). 


\section{Results and Discussion}

\subsection{Groundwater Level Data}

The manual water level measurements taken during sampling on March 4-5 and June 17-19, 2009, and prior recent monitoring events, are in Table 4.1. Evaluation of manual water level measurements (together with the contaminant distribution data discussed in Section 4.2) continues to suggest that three vertically distinguishable aquifer zones are present at Barnes: shallow, intermediate, and deep. The designations "S," "M," and "D" in monitoring well names (Table 4.1) were assigned at the time of well installation. They indicate shallow-, medium-, and deep-screened (relative depths) wells in an individual well cluster, rather than the aquifer zone screened. Table 4.2 shows the approximate water level elevations for wells screened in the three aquifer zones, as indicated by the long-term monitoring data accumulated since 2007. During the March 2009 event, the approximate water level elevations were 1,308 ft AMSL in wells screened in the shallow aquifer zone, 1,251-1,256 ft AMSL in wells screened in the intermediate zone, and 1,230-1,236 ft AMSL in wells screened in the deep aquifer zone. As in the prior monitoring events, three vertically distinguished aquifer zones are also evident in the June 2009 event (Table 4.2).

Water level data collected by the automatic recorders, which are coincident in time at all monitored locations, provide the primary basis for determination of the topology of the potentiometric surface at any point in the cycles of groundwater pumping and recovery. Water levels measured by hand over a finite time period in the areally distributed network of monitoring wells at this site cannot generally be relied on to yield a meaningful representation of groundwater flow directions under pumping conditions, because of the documented short-term, transient water level variations that are related to pumping cycles in the public water supply wells. Figure 4.1 presents water level contours (under non-pumping conditions) for February 11 and May 21, 2009, for the network of wells currently being monitored (see Section 3.1). Because of electrical malfunctions at recorders MW7 and MW16 (Figures 3.1 and 4.2a) in the eastern portion of the monitoring area, the groundwater flow pattern for pumping conditions cannot be illustrated for the current quarters. As noted below, however, the observed water level trends indicate that the frequency and magnitude of the pumping cycles previously documented for the public supply wells continued throughout the current review period. 
The hydrographs in Figures 4.2a and 4.2b summarize data for the period November 1, 2008, to May 21, 2009, for the recording transducers. Overall, the groundwater level trends in the deeper monitoring wells (Figure 4.2a) were similar to those observed previously. Levels were generally stable through February-April but began to rise in May.

Prior to November 2008, data from recorders in the deep portion of the aquifer (particularly MW15D) suggested the presence of vertical hydraulic gradients. In November 2008, wells in the intermediate portion of the aquifer (MW10S, MW11M, MW12M, MW13S, and MW17; Table 4.1) were equipped with automatic water level recorders to generate detailed data on the potential temporal variability of the hydraulic heads in this aquifer zone. The observed groundwater levels in the intermediate zone (Figure 4.2b) do not show the degree of drawdown response observed in the deep wells.

These data, together with the analyses of groundwater samples for VOCs discussed in Section 4.2, support a plausible working interpretation for the movement of groundwater (and carbon tetrachloride) in the study area. The existing results suggest that the entire saturated sequence at Barnes is hydraulically interconnected but varies internally in both vertical and horizontal permeability. The permeability in the more shaly parts of the section (which include the intermediate aquifer zone) appears to be generally lower than the permeability in the deep aquifer zone, and migration pathways might therefore be more complex in the shaly materials. The shaly materials of the intermediate zone appear to have sufficient vertical permeability to have allowed infiltration of carbon tetrachloride into the deeper parts of the section. The vertical permeability is still quite low, however, as evidenced by the significant vertical gradients documented in the nested wells (Table 4.2).

Most of the deep monitoring wells are associated with limestones (see Figures 4.1-4.5 in Argonne 2008a). The logs show that even though MW15D is considered a "deep" well, it is not completed in these limestones. MW15D has always returned much higher measured groundwater levels than would be expected, given its relative areal position at the site (Figures 3.1 and 4.2a) and its screened depth. This observation is qualitatively consistent with the hypothesis that the higher groundwater levels in MW15D are a reflection of lower permeability associated with the shales at this location, versus the nearby limestones - which appear to act as better carrier beds.

The observed groundwater levels in the intermediate-zone wells do not appear to define an apparent flow direction toward the public water supply wells, despite the mapped occurrence 
of the carbon tetrachloride plume in this stratigraphic interval (Section 4.2). The relative water levels do, however, appear qualitatively linked to the elevations of the screens in the respective intermediate-zone monitoring wells. Well MW11 has the highest recorded groundwater levels and the shallowest (in terms of elevation) screened interval, with MW10-MW12 the next lower in screened elevations (and water levels), and MW13-MW17 the lowest. The existing data empirically indicate that the measured "head" in each of these wells is more strongly influenced by the vertical position of the well screen than by the areal location of the well in the intermediate zone of the groundwater flow system.

\subsection{Analytical Results for Volatile Organic Compounds in Groundwater Samples and Lateral Distribution of the Contaminants}

The analytical data for VOCs in the groundwater samples collected in March and June 2009 are in Table 4.3, together with data for the previous sampling events at Barnes. The highest concentration of carbon tetrachloride in sitewide monitoring continues to be found at intermediate-zone well MW10S (located in the eastern portion of the former CCC/USDA facility and screened at 93-103 ft BGL), with detections of $49 \mu \mathrm{g} / \mathrm{L}$ in March 2009 and $76 \mu \mathrm{g} / \mathrm{L}$ in June 2009. Northwest of well MW10S (in the direction of flow toward the public wells when they are in operation), the carbon tetrachloride concentration decreased to $25-28 \mu \mathrm{g} / \mathrm{L}$ at $\mathrm{MW} 12 \mathrm{M}$ and 14-16 $\mu \mathrm{g} / \mathrm{L}$ at MW13S during the two sampling events.

The lateral distribution of carbon tetrachloride in groundwater in sampling events from July 2008 to June 2009 is illustrated in Figure 4.3. The distribution in March and June 2009 is similar to that during previous events. The most significant change during these reporting periods is the decrease in the concentration of carbon tetrachloride in public well PWS2 (from $1.7 \mu \mathrm{g} / \mathrm{L}$ in October 2008 to $<1 \mu \mathrm{g} / \mathrm{L}$ in March 2009 and $1.0 \mu \mathrm{g} / \mathrm{L}$ in June 2009). No contamination was detected in public well PWS3 during these periods. Because of the pulsing influence on groundwater flow patterns, depending on whether the public wells are operating, no clear migration trend toward the public wells has been evident in sitewide monitoring to date.

The lateral distribution of chloroform in groundwater in July 2008 to June 2009 (Figure 4.4) is also similar to the distribution during previous sampling events. The highest concentration of chloroform in sitewide sampling since 2007 has been found at well MW12M, located northwest of the former CCC/USDA facility and screened at 90-100 ft BGL (in the intermediate aquifer zone), with concentrations of 2.6-5.1 $\mu \mathrm{g} / \mathrm{L}$. 
The vertical distribution of carbon tetrachloride in groundwater indicates that the highest concentrations are present in the intermediate zone, at wells MW10S (49-76 $\mu \mathrm{g} / \mathrm{L}), \mathrm{MW} 12 \mathrm{M}$ (25-28 $\mu \mathrm{g} / \mathrm{L})$, and MW13S (14-16 $\mu \mathrm{g} / \mathrm{L})$. The deep-zone wells at these locations show lower concentrations $(4.8-5.3 \mu / \mathrm{L}$ at MW10D, a trace [estimated at $0.7 \mu \mathrm{g} / \mathrm{L}$ ] at MW12D, and 5.9-6.2 $\mu \mathrm{g} / \mathrm{L}$ at MW13D). Figures 4.5 and 4.6 illustrate the interpreted contaminant distributions in the intermediate and deep zones, respectively, in March 2009. The shallow-zone wells MW11S (sampled previously) and MW12S (sampled for the first time in June 2009) - continue to show no detectable concentrations of carbon tetrachloride (Table 4.3 and Figure 4.3).

In keeping with the groundwater level relationships outlined in Section 4.1, the above observations suggest that groundwater and carbon tetrachloride might be relatively less mobile in the (shaly) intermediate-zone lithologies than in the deeper limestones. Both vertical and horizontal hydraulic gradients are expected to drive contaminant migration in the shaly materials, while horizontal groundwater flow (and contaminant migration) might predominate in the deeper limestones. Because of the inferred higher permeability in the deeper limestones, the carbon tetrachloride in this zone might be more effectively mixed and diluted by groundwater movement in response to the oscillatory hydraulic gradients imparted by pumping of the public wells, while the movement of groundwater and hence carbon tetrachloride in the intermediatezone lithologies is more restricted. 
TABLE 4.1 Hand-measured water levels at Barnes, October 2008-May 2009.

\begin{tabular}{|c|c|c|c|c|c|c|c|c|c|c|c|}
\hline \multirow[b]{3}{*}{ Well } & \multirow{3}{*}{$\begin{array}{l}\text { Reference } \\
\text { Elevation } \\
\text { (ft AMSL) }\end{array}$} & \multicolumn{10}{|c|}{ Water Level on Date Indicated } \\
\hline & & \multicolumn{2}{|c|}{$10 / 22-24 / 08$} & \multicolumn{2}{|c|}{$11 / 19 / 08$} & \multicolumn{2}{|c|}{$2 / 11 / 09$} & \multicolumn{2}{|c|}{$3 / 4-5 / 09$} & \multicolumn{2}{|c|}{$5 / 21 / 09$} \\
\hline & & $\mathrm{ft}$ TOC $^{\mathrm{a}}$ & $\mathrm{ft}$ AMSL & $\mathrm{ft}$ TOCa & $\mathrm{ft}$ AMSL & $\mathrm{ft}$ TOC $\mathrm{a}$ & $\mathrm{ft}$ AMSL & $\mathrm{ft}$ TOC $^{\mathrm{a}}$ & $\mathrm{ft}$ AMSL & $\mathrm{ft}$ TOC ${ }^{\mathrm{a}}$ & $\mathrm{ft}$ AMSL \\
\hline \multicolumn{12}{|c|}{ Shallow aquifer zone } \\
\hline MW1S & 1351.58 & Dry & - & Dry & - & $N M^{b}$ & - & - & - & - & - \\
\hline MW11S & 1336.58 & 22.50 & 1314.08 & NM & - & NM & - & 28.00 & 1308.58 & - & - \\
\hline MW12S & 1327.46 & Dry & - & Dry & - & NM & - & - & - & - & - \\
\hline \multicolumn{12}{|c|}{ Intermediate aquifer zone } \\
\hline MW10S & 1331.33 & 72.00 & 1259.33 & 72.13 & 1259.20 & 75.13 & 1256.20 & 76.00 & 1255.33 & 74.56 & 1256.77 \\
\hline MW11M & 1336.51 & 77.80 & 1258.71 & 77.40 & 1259.11 & 79.87 & 1256.64 & 80.30 & 1256.21 & 79.42 & 1257.09 \\
\hline MW12M & 1327.46 & 69.72 & 1257.74 & 68.69 & 1258.77 & 71.46 & 1256.00 & 76.50 & 1250.96 & 70.97 & 1256.49 \\
\hline MW13S & 1342.36 & 86.00 & 1256.36 & 85.02 & 1257.34 & 87.98 & 1254.38 & 88.75 & 1253.61 & 87.11 & 1255.25 \\
\hline MW17 & 1351.77 & 95.15 & 1256.62 & 94.81 & 1256.96 & 97.48 & 1254.29 & 98.10 & 1253.67 & 96.71 & 1255.06 \\
\hline \multicolumn{12}{|c|}{ Deep aquifer zone } \\
\hline MW1D & 1351.33 & 113.77 & 1237.56 & 113.62 & 1237.71 & 118.55 & 1232.78 & 119.90 & 1231.43 & 116.82 & 1234.51 \\
\hline MW2D & 1348.85 & 113.55 & 1235.30 & 111.61 & 1237.24 & 116.34 & 1232.51 & 117.10 & 1231.75 & 114.59 & 1234.26 \\
\hline MW3D & 1345.99 & 108.50 & 1237.49 & 108.20 & 1237.79 & 113.05 & 1232.94 & 116.10 & 1229.89 & 111.28 & 1234.71 \\
\hline MW4D & 1326.32 & 89.90 & 1236.42 & 90.72 & 1235.60 & 94.34 & 1231.98 & 94.75 & 1231.57 & - & - \\
\hline MW5 & 1327.20 & 91.40 & 1235.80 & NM & - & NM & - & 96.90 & 1230.30 & - & - \\
\hline MW6S & 1323.13 & 84.60 & 1238.53 & NM & - & NM & - & 87.00 & 1236.13 & - & - \\
\hline MW6D & 1323.15 & 87.15 & 1236.00 & NM & - & NM & - & 93.00 & 1230.15 & - & - \\
\hline MW7 & 1329.91 & 94.90 & 1235.01 & 96.67 & 1233.24 & 98.19 & 1231.72 & 99.80 & 1230.11 & 96.50 & 1233.41 \\
\hline MW8 & 1330.06 & 93.40 & 1236.66 & NM & - & NM & - & 98.60 & 1231.46 & - & - \\
\hline MW9 & 1321.86 & 86.60 & 1235.26 & 86.19 & 1235.67 & 89.91 & 1231.95 & 90.40 & 1231.46 & 88.16 & 1233.70 \\
\hline MW10D & 1331.33 & 95.00 & 1236.33 & NM & - & 113.69 & 1217.64 & 101.30 & 1230.03 & - & - \\
\hline MW11D & 1336.53 & 101.03 & 1235.50 & NM & - & NM & - & 105.03 & 1231.50 & - & - \\
\hline MW12D & 1327.52 & 91.12 & 1236.40 & NM & - & NM & - & 96.80 & 1230.72 & - & - \\
\hline MW13D & 1342.37 & 105.30 & 1237.07 & NM & - & NM & - & 110.58 & 1231.79 & - & - \\
\hline MW14S & 1332.69 & 96.20 & 1236.49 & NM & - & NM & - & 101.30 & 1231.39 & - & - \\
\hline MW14D & 1332.74 & 96.10 & 1236.64 & 96.18 & 1236.56 & 100.57 & 1232.17 & 103.20 & 1229.54 & 98.89 & 1233.85 \\
\hline
\end{tabular}


TABLE 4.1 (Cont.)

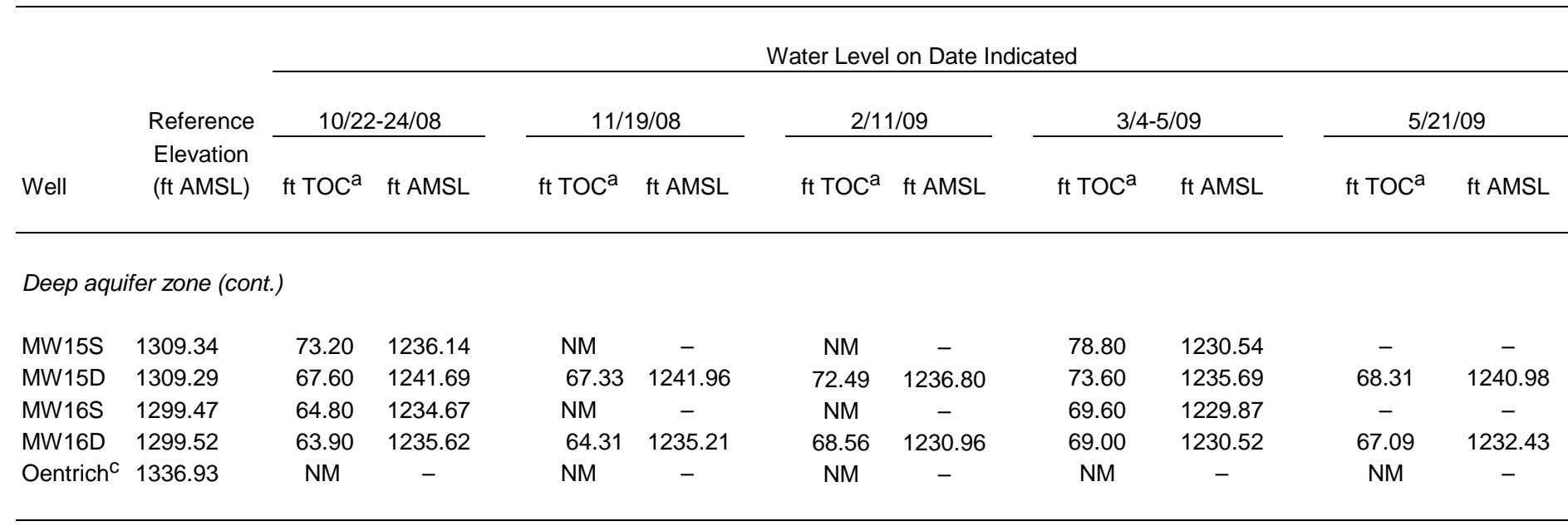

a TOC, top of casing.

b NM, not measured

c The Oentrich well water level was measured from the concrete at the top of the well vault. The value shown was corrected by $5.5 \mathrm{ft}$ to give a measured depth from the top of the casing. 
TABLE 4.2 Elevation ranges measured for the three aquifer zones, June 2007-July 2009.

\begin{tabular}{lccc}
\hline & \multicolumn{3}{c}{ Elevation of Aquifer Zone (ft AMSL) } \\
\cline { 2 - 4 } Date & Shallow & Intermediate & Deep \\
\hline June 2009 & $1,274-1,310$ & $1,255-1,258$ & $1,232-1,241$ \\
March 2009 & 1,308 & $1,251-1,256$ & $1,229-1,236$ \\
November 2008 & - & $1,257-1,259$ & $1,233-1,242$ \\
October 2008 & 1,314 & $1,256-1,259$ & $1,235-1,242$ \\
July 2008 & 1,312 & $1,255-1,258$ & $1,229-1,239$ \\
March 2008 & 1,309 & $1,250-1,254$ & $1,223-1,229$ \\
November 2007 & 1,307 & $1,249-1,254$ & $1,220-1,239$ \\
June 2007 & $1,276-1,314$ & $1,247-1,254$ & $1,221-1,228$ \\
\hline
\end{tabular}


TABLE 4.3 Analytical results from the AGEM Laboratory for volatile organic compounds in groundwater samples collected at Barnes, July 2006 to June 2009.

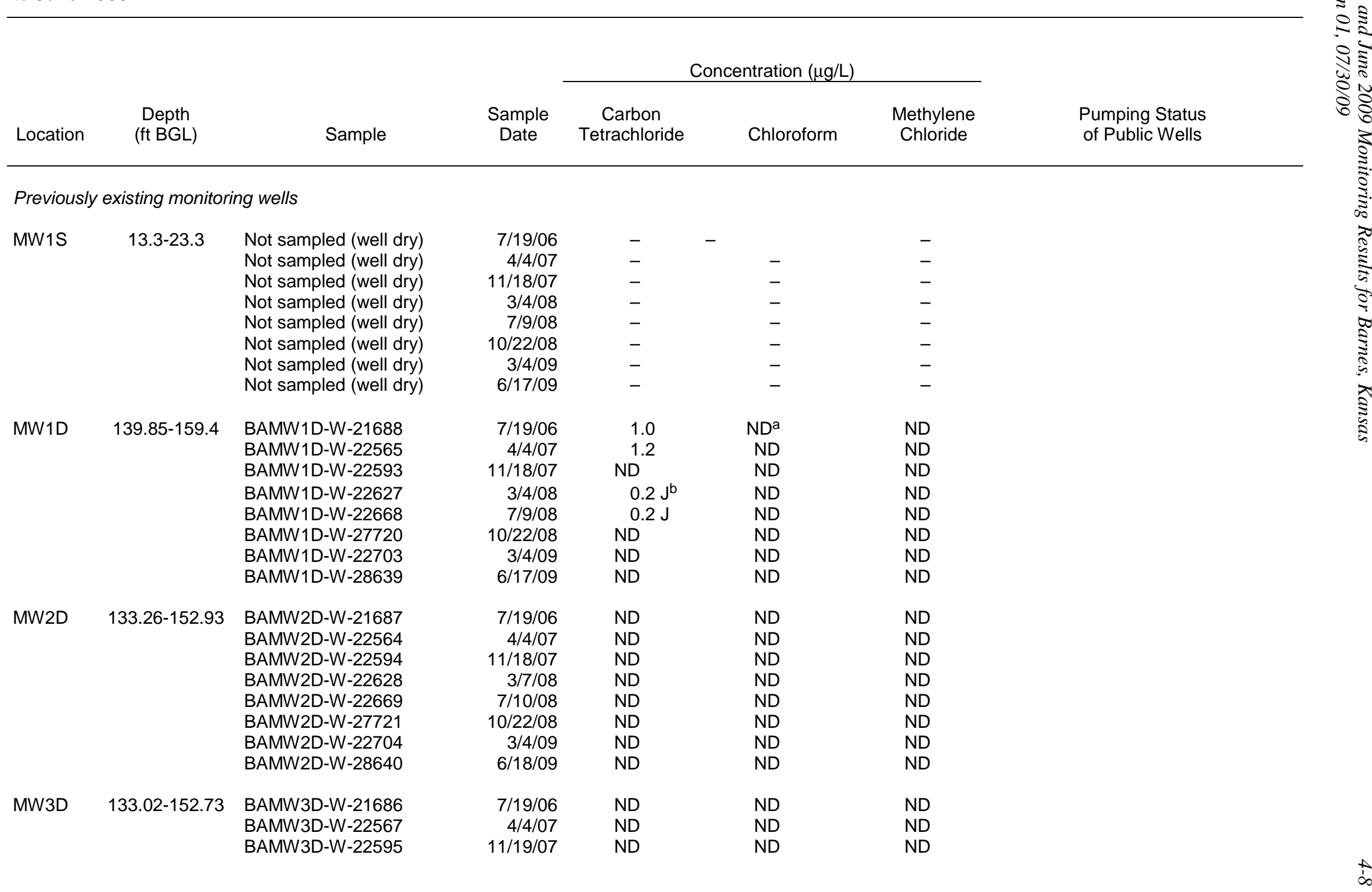


TABLE 4.3 (Cont.)

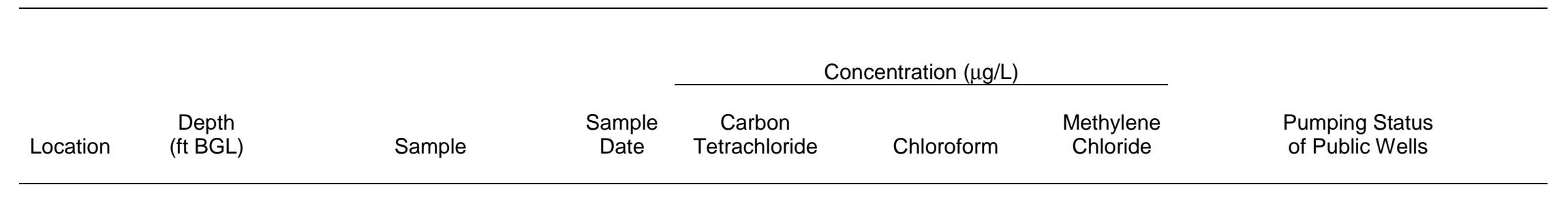

Previously existing monitoring wells (cont.)

\begin{tabular}{|c|c|c|c|c|c|c|}
\hline MW3D & $133.02-152.73$ & $\begin{array}{l}\text { BAMW3D-W-22629 } \\
\text { BAMW3D-W-22670 } \\
\text { BAMW3D-W-27722 } \\
\text { BAMW3D-W-22705 } \\
\text { BAMW3D-W-28641 }\end{array}$ & $\begin{array}{r}3 / 7 / 08 \\
7 / 10 / 08 \\
10 / 22 / 08 \\
3 / 4 / 09 \\
6 / 17 / 09\end{array}$ & $\begin{array}{l}\text { ND } \\
\text { ND } \\
\text { ND } \\
\text { ND } \\
\text { ND }\end{array}$ & $\begin{array}{l}\text { ND } \\
\text { ND } \\
\text { ND } \\
\text { ND } \\
\text { ND }\end{array}$ & $\begin{array}{l}\text { ND } \\
\text { ND } \\
\text { ND } \\
\text { ND } \\
\text { ND }\end{array}$ \\
\hline MW4D & $98.38-118.22$ & $\begin{array}{l}\text { BAMW4D-W-21690 } \\
\text { BAMW4D-W-22583 } \\
\text { BAMW4D-W-22596 } \\
\text { BAMW4D-W-22642 } \\
\text { BAMW4D-W-22671 } \\
\text { BAMW4D-W-27723 } \\
\text { BAMW4D-W-22706 } \\
\text { BAMW4D-W-28642 }\end{array}$ & $\begin{array}{r}7 / 20 / 06 \\
4 / 6 / 07 \\
11 / 19 / 07 \\
3 / 9 / 08 \\
7 / 12 / 08 \\
10 / 23 / 08 \\
3 / 5 / 09 \\
6 / 18 / 09\end{array}$ & $\begin{array}{c}2.1 \\
3.5 \\
1.7 \\
18 \\
9.4 \\
7.6 \\
7.2 \\
9.1\end{array}$ & $\begin{array}{l}\text { ND } \\
0.1 \mathrm{~J} \\
0.4 \mathrm{~J} \\
0.4 \mathrm{~J} \\
0.5 \mathrm{~J} \\
\text { ND } \\
0.3 \mathrm{~J} \\
\text { ND }\end{array}$ & $\begin{array}{l}\text { ND } \\
\text { ND } \\
\text { ND } \\
\text { ND } \\
\text { ND } \\
\text { ND } \\
\text { ND } \\
\text { ND }\end{array}$ \\
\hline
\end{tabular}

CCC/USDA wells installed during the 2006-2007 investigation

\begin{tabular}{|c|c|c|c|c|c|c|}
\hline MW5 & $110-120$ & $\begin{array}{l}\text { BAMW5-W-22589 } \\
\text { BAMW5-W-22597 } \\
\text { BAMW5-W-22637 } \\
\text { BAMW5-W-22672 } \\
\text { BAMW5-W-27724 } \\
\text { BAMW5-W-22707 } \\
\text { BAMW5-W-28643 }\end{array}$ & $\begin{array}{r}4 / 6 / 07 \\
11 / 19 / 07 \\
3 / 8 / 08 \\
7 / 11 / 08 \\
10 / 23 / 08 \\
3 / 5 / 09 \\
6 / 19 / 09\end{array}$ & $\begin{array}{l}0.6 \mathrm{~J} \\
0.6 \mathrm{~J} \\
0.7 \mathrm{~J} \\
\mathrm{ND} \\
3.0 \\
3.2 \\
4.8\end{array}$ & $\begin{array}{l}\text { ND } \\
\text { ND } \\
\text { ND } \\
\text { ND } \\
\text { ND } \\
\text { ND } \\
\text { ND }\end{array}$ & $\begin{array}{l}\text { ND } \\
\text { ND } \\
\text { ND } \\
\text { ND } \\
\text { ND } \\
\text { ND } \\
\text { ND }\end{array}$ \\
\hline MW6S & $90.5-100.5$ & $\begin{array}{l}\text { Not sampled (well dry) } \\
\text { BAMW6S-W-22598 } \\
\text { BAMW6S-W-22635 } \\
\text { BAMW6S-W-22673 } \\
\text { BAMW6S-W-27725 } \\
\text { BAMW6S-W-22708 } \\
\text { BAMW6S-W-28644 }\end{array}$ & $\begin{array}{r}4 / 4 / 07 \\
11 / 19 / 07 \\
3 / 8 / 08 \\
7 / 11 / 08 \\
10 / 23 / 08 \\
3 / 5 / 09 \\
6 / 18 / 09\end{array}$ & $\begin{array}{l}-\overline{0} \\
0.3 \mathrm{~J} \\
0.4 \mathrm{~J} \\
\text { ND } \\
\text { ND } \\
\text { ND } \\
\text { ND }\end{array}$ & $\begin{array}{l}- \\
N D \\
N D \\
N D \\
N D \\
N D \\
N D\end{array}$ & $\begin{array}{l}- \\
\text { ND } \\
\text { ND } \\
\text { ND } \\
\text { ND } \\
\text { ND } \\
\text { ND }\end{array}$ \\
\hline
\end{tabular}


TABLE 4.3 (Cont.)

Concentration $(\mu \mathrm{g} / \mathrm{L})$

\begin{tabular}{|c|c|c|c|c|c|c|c|}
\hline Location & $\begin{array}{c}\text { Depth } \\
\text { (ft BGL) }\end{array}$ & Sample & $\begin{array}{c}\text { Sample } \\
\text { Date }\end{array}$ & $\begin{array}{c}\text { Carbon } \\
\text { Tetrachloride }\end{array}$ & Chloroform & $\begin{array}{l}\text { Methylene } \\
\text { Chloride }\end{array}$ & $\begin{array}{l}\text { Pumping Status } \\
\text { of Public Wells }\end{array}$ \\
\hline
\end{tabular}

CCC/USDA wells installed during the 2006-2007 investigation (cont.)

\begin{tabular}{|c|c|c|c|c|c|}
\hline MW6D & $105-115$ & $\begin{array}{l}\text { BAMW6D-W-22573 } \\
\text { BAMW6D-W-22599 } \\
\text { BAMW6D-W-22636 } \\
\text { BAMW6D-W-22674 } \\
\text { BAMW6D-W-27726 } \\
\text { BAMW6D-W-22709 } \\
\text { BAMW6D-W-28645 }\end{array}$ & $\begin{array}{r}4 / 5 / 07 \\
11 / 19 / 07 \\
3 / 8 / 08 \\
7 / 11 / 08 \\
10 / 23 / 08 \\
3 / 5 / 09 \\
6 / 18 / 09\end{array}$ & $\begin{array}{l}\text { ND } \\
0.5 \mathrm{~J} \\
0.8 \mathrm{~J} \\
0.9 \mathrm{~J} \\
1.1 \\
1.4 \\
1.5\end{array}$ & $\begin{array}{l}\text { ND } \\
\text { ND } \\
\text { ND } \\
\text { ND } \\
\text { ND } \\
\text { ND } \\
\text { ND }\end{array}$ \\
\hline MW7 & $116-126$ & $\begin{array}{l}\text { BAMW7-W-22588 } \\
\text { BAMW7-W-22600 } \\
\text { BAMW7-W-22643 } \\
\text { BAMW7-W-22675 } \\
\text { BAMW7-W-27727 } \\
\text { BAMW7-W-22710 } \\
\text { BAMW7-W-28646 }\end{array}$ & $\begin{array}{r}4 / 6 / 07 \\
11 / 19 / 07 \\
3 / 9 / 08 \\
7 / 12 / 08 \\
10 / 23 / 08 \\
3 / 5 / 09 \\
6 / 19 / 09\end{array}$ & $\begin{array}{l}1.0 \\
2.6 \\
2.8 \\
1.7 \\
2.1 \\
1.4 \\
1.4\end{array}$ & $\begin{array}{l}\text { ND } \\
\text { ND } \\
\text { ND } \\
\text { ND } \\
\text { ND } \\
\text { ND } \\
\text { ND }\end{array}$ \\
\hline MW8 & $110-120$ & $\begin{array}{l}\text { BAMW8-W-22584 } \\
\text { BAMW8-W-22601 } \\
\text { BAMW8-W-22652 } \\
\text { BAMW8-W-22676 } \\
\text { BAMW8-W-27728 } \\
\text { BAMW8-W-22711 } \\
\text { BAMW8-W-28647 }\end{array}$ & $\begin{array}{r}4 / 6 / 07 \\
11 / 19 / 07 \\
3 / 10 / 08 \\
7 / 11 / 08 \\
10 / 23 / 08 \\
3 / 5 / 09 \\
6 / 19 / 09\end{array}$ & $\begin{array}{l}14 \\
23 \\
19 \\
21 \\
24 \\
20 \\
26\end{array}$ & $\begin{array}{l}0.7 \mathrm{~J} \\
0.6 \mathrm{~J} \\
0.6 \mathrm{~J} \\
0.6 \mathrm{~J} \\
1.0 \\
1.3 \\
1.7\end{array}$ \\
\hline MW9 & $100-110$ & $\begin{array}{l}\text { BAMW9-W-22582 } \\
\text { BAMW9-W-22602 } \\
\text { BAMW9-W-22647 } \\
\text { BAMW9-W-22678 } \\
\text { BAMW9-W-27729 } \\
\text { BAMW9-W-22712 } \\
\text { BAMW9-W-28648 }\end{array}$ & $\begin{array}{r}4 / 5 / 07 \\
11 / 19 / 07 \\
3 / 9 / 08 \\
7 / 11 / 08 \\
10 / 24 / 08 \\
3 / 5 / 09 \\
6 / 17 / 09\end{array}$ & $\begin{array}{l}1.0 \\
7.7 \\
3.0 \\
1.3 \\
2.2 \\
2.3 \\
1.1\end{array}$ & $\begin{array}{l}\text { ND } \\
0.6 \mathrm{~J} \\
0.3 \mathrm{~J} \\
0.3 \mathrm{~J} \\
0.2 \mathrm{~J} \\
\text { ND } \\
\text { ND }\end{array}$ \\
\hline
\end{tabular}


TABLE 4.3 (Cont.)

Concentration $(\mu \mathrm{g} / \mathrm{L})$

\begin{tabular}{|c|c|c|c|c|c|c|}
\hline Location & $\begin{array}{l}\text { Depth } \\
\text { (ft BGL) }\end{array}$ & Sample & $\begin{array}{l}\text { Sample } \\
\text { Date }\end{array}$ & $\begin{array}{c}\text { Carbon } \\
\text { Tetrachloride }\end{array}$ & Chloroform & $\begin{array}{l}\text { Methy } \\
\text { Chlor }\end{array}$ \\
\hline \multicolumn{7}{|c|}{ CCC/USDA wells installed during the 2006-2007 investigation (cont.) } \\
\hline \multirow[t]{7}{*}{ MW10S } & $93-103$ & BAMW10S-W-22586 & $4 / 6 / 07$ & 20 & 1.4 & \\
\hline & & BAMW10S-W-22603 & $11 / 19 / 07$ & 11 & $0.7 \mathrm{~J}$ & \\
\hline & & BAMW10S-W-22649 & 3/10/08 & 56 & 2.0 & \\
\hline & & BAMW10S-W-22679 & $7 / 11 / 08$ & 49 & 1.8 & \\
\hline & & BAMW10S-W-27730 & $10 / 23 / 08$ & 68 & 2.3 & \\
\hline & & BAMW10S-W-22713 & $3 / 5 / 09$ & 49 & 2.1 & \\
\hline & & BAMW10S-W-28649 & $6 / 19 / 09$ & 76 & 2.5 & \\
\hline \multirow[t]{7}{*}{ MW10D } & $115-125$ & BAMW10D-W-22585 & $4 / 6 / 07$ & 2.4 & $0.2 \mathrm{~J}$ & \\
\hline & & BAMW10D-W-22604 & $11 / 19 / 07$ & 6.3 & $0.5 \mathrm{~J}$ & \\
\hline & & BAMW10D-W-22646 & $3 / 9 / 08$ & 5.7 & $0.5 \mathrm{~J}$ & \\
\hline & & BAMW10D-W-22680 & $7 / 11 / 08$ & 3.9 & $0.7 \mathrm{~J}$ & \\
\hline & & BAMW10D-W-27731 & $10 / 23 / 08$ & 4.4 & $0.6 \mathrm{~J}$ & \\
\hline & & BAMW10D-W-22714 & $3 / 5 / 09$ & 5.3 & $0.4 \mathrm{~J}$ & TV \\
\hline & & BAMW10D-W-28650 & $6 / 19 / 09$ & 4.8 & $0.6 \mathrm{~J}$ & \\
\hline \multirow{7}{*}{ MW11S } & $40-50$ & BAMW11S-W-22570 & $4 / 4 / 07$ & ND & 1.1 & \\
\hline & & BAMW11S-W-22605 & $11 / 19 / 07$ & ND & $0.6 \mathrm{~J}$ & \\
\hline & & BAMW11S-W-22630 & $3 / 5 / 08$ & ND & $0.6 \mathrm{~J}$ & \\
\hline & & BAMW11S-W-22681 & $7 / 10 / 08$ & ND & $0.4 \mathrm{~J}$ & \\
\hline & & BAMW11S-W-27732 & $10 / 23 / 08$ & ND & $0.3 \mathrm{~J}$ & \\
\hline & & BAMW11S-W-22715 & $3 / 4 / 09$ & ND & ND & \\
\hline & & BAMW11S-W-28651 & $6 / 19 / 09$ & ND & ND & $\mathrm{N}$ \\
\hline \multirow{7}{*}{ MW11M } & $90-100$ & BAMW11M-W-22572 & $4 / 5 / 07$ & ND & ND & $N$ \\
\hline & & BAMW11M-W-22606 & $11 / 19 / 07$ & 3.7 & ND & \\
\hline & & BAMW11M-W-22644 & $3 / 6 / 08$ & 2.4 & $0.5 \mathrm{~J}$ & \\
\hline & & BAMW11M-W-22682 & $7 / 10 / 08$ & 2.4 & $0.7 \mathrm{~J}$ & \\
\hline & & BAMW11M-W-27733 & $10 / 23 / 08$ & 1.7 & 2.1 & T \\
\hline & & BAMW11M-W-22716 & $3 / 4 / 09$ & $0.6 \mathrm{~J}$ & 1.2 & 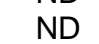 \\
\hline & & BAMW11M-W-28652 & $6 / 19 / 09$ & ND & 1.1 & 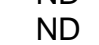 \\
\hline
\end{tabular}

Pumping Status of Public Wells 
TABLE 4.3 (Cont.)

Concentration $(\mu \mathrm{g} / \mathrm{L})$

\begin{tabular}{|c|c|c|c|c|c|c|}
\hline Location & $\begin{array}{l}\text { Depth } \\
\text { (ft BGL) }\end{array}$ & Sample & $\begin{array}{l}\text { Sample } \\
\text { Date }\end{array}$ & $\begin{array}{c}\text { Carbon } \\
\text { Tetrachloride }\end{array}$ & Chloroform & $\begin{array}{l}\text { Methy } \\
\text { Chlo }\end{array}$ \\
\hline \multicolumn{7}{|c|}{ CCC/USDA wells installed during the 2006-2007 investigation (cont.) } \\
\hline \multirow[t]{7}{*}{ MW11D } & $125-135$ & BAMW11D-W-22571 & $4 / 4 / 07$ & 1.1 & ND & \\
\hline & & BAMW11D-W-22607 & $11 / 19 / 07$ & $0.8 \mathrm{~J}$ & ND & \\
\hline & & BAMW11D-W-22639 & $3 / 5 / 08$ & $0.4 \mathrm{~J}$ & ND & \\
\hline & & BAMW11D-W-22683 & 7/10/08 & $0.9 \mathrm{~J}$ & ND & \\
\hline & & BAMW11D-W-27734 & $10 / 23 / 08$ & $0.9 \mathrm{~J}$ & $0.2 \mathrm{~J}$ & \\
\hline & & BAMW11D-W-22717 & 3/4/09 & $0.8 \mathrm{~J}$ & ND & \\
\hline & & BAMW11D-W-28653 & 6/19/09 & ND & ND & \\
\hline \multirow[t]{7}{*}{ MW12S } & $43-50$ & Not sampled (well dry) & $4 / 5 / 07$ & - & - & \\
\hline & & Not sampled (well dry) & $11 / 19 / 07$ & - & - & \\
\hline & & Not sampled (well dry) & 3/10/08 & - & - & \\
\hline & & Not sampled (well dry) & $7 / 10 / 08$ & - & - & \\
\hline & & Not sampled (well dry) & 10/22/08 & - & - & \\
\hline & & Not sampled (well dry) & $3 / 4 / 09$ & - & - & \\
\hline & & BAMW12S-W-28654 & $6 / 19 / 09$ & ND & ND & \\
\hline \multirow[t]{7}{*}{ MW12M } & $90-100$ & BAMW12M-W-22580 & $4 / 5 / 07$ & 20 & 4.2 & \\
\hline & & BAMW12M-W-22609 & $11 / 19 / 07$ & 18 & 5.1 & \\
\hline & & BAMW12M-W-22651 & $3 / 10 / 08$ & 18 & 2.6 & \\
\hline & & BAMW12M-W-22685 & $7 / 10 / 08$ & 27 & 4.2 & \\
\hline & & BAMW12M-W-27736 & $10 / 22 / 08$ & 18 & 4.5 & \\
\hline & & BAMW12M-W-22719 & $3 / 4 / 09$ & 25 & 4.4 & \\
\hline & & BAMW12M-W-28655 & 6/19/09 & 28 & 4.9 & \\
\hline \multirow[t]{7}{*}{ MW12D } & $115-125$ & BAMW12D-W-22576 & $4 / 5 / 07$ & $0.6 \mathrm{~J}$ & ND & \\
\hline & & BAMW12D-W-22610 & $11 / 18 / 07$ & & ND & \\
\hline & & BAMW12D-W-22641 & 3/9/08 & 1.0 & ND & \\
\hline & & BAMW12D-W-22686 & 7/11/08 & $0.7 \mathrm{~J}$ & ND & \\
\hline & & BAMW12D-W-27737 & 10/22/08 & $0.9 \mathrm{~J}$ & ND & \\
\hline & & BAMW12D-W-22757 & $3 / 4 / 09$ & $0.7 \mathrm{~J}$ & ND & \\
\hline & & BAMW12D-W-28656 & 6/19/09 & ND & ND & $\mathrm{N}$ \\
\hline
\end{tabular}

Pumping Status of Public Wells 
TABLE 4.3 (Cont.)

Concentration $(\mu \mathrm{g} / \mathrm{L})$

\begin{tabular}{|c|c|c|c|c|c|c|c|}
\hline Location & $\begin{array}{l}\text { Depth } \\
\text { (ft BGL) }\end{array}$ & Sample & $\begin{array}{l}\text { Sample } \\
\text { Date }\end{array}$ & $\begin{array}{c}\text { Carbon } \\
\text { Tetrachloride }\end{array}$ & Chloroform & $\begin{array}{l}\text { Methylene } \\
\text { Chloride }\end{array}$ & $\begin{array}{l}\text { Pumping Status } \\
\text { of Public Wells }\end{array}$ \\
\hline
\end{tabular}

CCC/USDA wells installed during the 2006-2007 investigation (cont.)

\begin{tabular}{|c|c|c|c|c|c|c|}
\hline MW13S & $112-122$ & $\begin{array}{l}\text { BAMW13S-W-22575 } \\
\text { BAMW13S-W-22611 } \\
\text { BAMW13S-W-22650 } \\
\text { BAMW13S-W-22687 } \\
\text { BAMW13S-W-27738 } \\
\text { BAMW13S-W-22758 } \\
\text { BAMW13S-W-28657 }\end{array}$ & $\begin{array}{r}4 / 5 / 07 \\
11 / 19 / 07 \\
3 / 10 / 08 \\
7 / 9 / 08 \\
10 / 22 / 08 \\
3 / 4 / 09 \\
6 / 18 / 09\end{array}$ & $\begin{array}{l}21 \\
17 \\
17 \\
17 \\
20 \\
14 \\
16\end{array}$ & $\begin{array}{l}1.6 \\
1.8 \\
1.5 \\
1.9 \\
1.6 \\
1.1 \\
1.1\end{array}$ & $\begin{array}{l}\text { ND } \\
\text { ND } \\
\text { ND } \\
\text { ND } \\
\text { ND } \\
\text { ND } \\
\text { ND }\end{array}$ \\
\hline MW13D & $127-137$ & $\begin{array}{l}\text { BAMW13D-W-22574 } \\
\text { BAMW13D-W-22612 } \\
\text { BAMW13D-W-22645 } \\
\text { BAMW13D-W-22688 } \\
\text { BAMW13D-W-27739 } \\
\text { BAMW13D-W-22759 } \\
\text { BAMW13D-W-28658 }\end{array}$ & $\begin{array}{r}4 / 5 / 07 \\
11 / 19 / 07 \\
3 / 9 / 08 \\
7 / 9 / 08 \\
10 / 22 / 08 \\
3 / 4 / 09 \\
6 / 18 / 09\end{array}$ & $\begin{array}{c}3.5 \\
5.9 \\
11 \\
5.9 \\
6.6 \\
5.9 \\
6.2\end{array}$ & $\begin{array}{l}0.4 \mathrm{~J} \\
0.2 \mathrm{~J} \\
1.1 \\
0.9 \mathrm{~J} \\
0.6 \mathrm{~J} \\
0.6 \mathrm{~J} \\
\mathrm{ND}\end{array}$ & $\begin{array}{l}\text { ND } \\
\text { ND } \\
\text { ND } \\
\text { ND } \\
\text { ND } \\
\text { ND } \\
\text { ND }\end{array}$ \\
\hline MW14S & $108-118$ & $\begin{array}{l}\text { BAMW14S-W-22569 } \\
\text { BAMW14S-W-22613 } \\
\text { BAMW14S-W-22640 } \\
\text { BAMW14S-W-22689 } \\
\text { BAMW14S-W-27740 } \\
\text { BAMW14S-W-28620 } \\
\text { BAMW14S-W-28659 }\end{array}$ & $\begin{array}{r}4 / 4 / 07 \\
11 / 18 / 07 \\
3 / 8 / 08 \\
7 / 10 / 08 \\
10 / 22 / 08 \\
3 / 4 / 09 \\
6 / 18 / 09\end{array}$ & $\begin{array}{l}0.9 \mathrm{~J} \\
1.2 \\
4.3 \\
5.6 \\
5.6 \\
5.6 \\
3.7\end{array}$ & $\begin{array}{l}\text { ND } \\
\text { ND } \\
0.3 \mathrm{~J} \\
0.3 \mathrm{~J} \\
0.3 \mathrm{~J} \\
0.4 \mathrm{~J} \\
0.6 \mathrm{~J}\end{array}$ & $\begin{array}{l}\text { ND } \\
\text { ND } \\
\text { ND } \\
\text { ND } \\
\text { ND } \\
\text { ND } \\
\text { ND }\end{array}$ \\
\hline MW14D & 123-133 & $\begin{array}{l}\text { BAMW14D-W-22568 } \\
\text { BAMW14D-W-22614 } \\
\text { BAMW14D-W-22638 } \\
\text { BAMW14D-W-22690 } \\
\text { BAMW14D-W-27741 } \\
\text { BAMW14D-W-28621 } \\
\text { BAMW14D-W-28660 }\end{array}$ & $\begin{array}{r}4 / 4 / 07 \\
11 / 18 / 07 \\
3 / 8 / 08 \\
7 / 10 / 08 \\
10 / 22 / 08 \\
3 / 5 / 09 \\
6 / 18 / 09\end{array}$ & $\begin{array}{c}1.2 \\
0.6 \mathrm{~J} \\
0.7 \mathrm{~J} \\
0.5 \mathrm{~J} \\
\text { ND } \\
0.6 \mathrm{~J} \\
\text { ND }\end{array}$ & $\begin{array}{l}\text { ND } \\
\text { ND } \\
\text { ND } \\
\text { ND } \\
\text { ND } \\
\text { ND } \\
\text { ND }\end{array}$ & $\begin{array}{l}\text { ND } \\
\text { ND } \\
\text { ND } \\
\text { ND } \\
\text { ND } \\
\text { ND } \\
\text { ND }\end{array}$ \\
\hline
\end{tabular}


TABLE 4.3 (Cont.)

Concentration $(\mu \mathrm{g} / \mathrm{L})$

\begin{tabular}{|c|c|c|c|c|c|c|}
\hline Location & $\begin{array}{l}\text { Depth } \\
\text { (ft BGL) }\end{array}$ & Sample & $\begin{array}{l}\text { Sample } \\
\text { Date }\end{array}$ & $\begin{array}{c}\text { Carbon } \\
\text { Tetrachloride }\end{array}$ & Chloroform & $\begin{array}{l}\text { Methy } \\
\text { Chlo }\end{array}$ \\
\hline \multicolumn{7}{|c|}{ CCC/USDA wells installed during the 2006-2007 investigation (cont.) } \\
\hline \multirow[t]{7}{*}{ MW15S } & $88-98$ & BAMW15S-W-22560 & $4 / 4 / 07$ & 1.5 & ND & \\
\hline & & BAMW15S-W-22615 & $11 / 18 / 07$ & 8.7 & $0.4 \mathrm{~J}$ & \\
\hline & & BAMW15S-W-22648 & 3/10/08 & 1.8 & $0.2 \mathrm{~J}$ & \\
\hline & & BAMW15S-W-22691 & $7 / 12 / 08$ & 2.2 & $0.3 \mathrm{~J}$ & \\
\hline & & BAMW15S-W-27742 & 10/23/08 & 1.9 & ND & \\
\hline & & BAMW15S-W-28622 & $3 / 5 / 09$ & 2.5 & ND & \\
\hline & & BAMW15S-W-28661 & $6 / 17 / 09$ & 3.2 & $0.5 \mathrm{~J}$ & \\
\hline \multirow[t]{7}{*}{ MW15D } & $105-115$ & BAMW15D-W-22561 & $4 / 4 / 07$ & ND & ND & \\
\hline & & BAMW15D-W-22616 & $11 / 18 / 07$ & ND & ND & \\
\hline & & BAMW15D-W-22631 & $3 / 8 / 08$ & $0.2 \mathrm{~J}$ & ND & \\
\hline & & BAMW15D-W-22692 & 7/12/08 & ND & ND & \\
\hline & & BAMW15D-W-27743 & $10 / 24 / 08$ & ND & ND & \\
\hline & & BAMW15D-W-28623 & $3 / 5 / 09$ & ND & ND & \\
\hline & & BAMW15D-W-28662 & $6 / 17 / 09$ & ND & ND & \\
\hline \multirow{7}{*}{ MW16S } & $76-86$ & BAMW16S-W-22563 & $4 / 4 / 07$ & ND & ND & \\
\hline & & BAMW16S-W-22617 & $11 / 19 / 07$ & ND & ND & \\
\hline & & BAMW16S-W-22632 & $3 / 7 / 08$ & $0.4 \mathrm{~J}$ & ND & \\
\hline & & BAMW16S-W-22693 & $7 / 11 / 08$ & ND & ND & \\
\hline & & BAMW16S-W-27744 & $10 / 23 / 08$ & $0.9 \mathrm{~J}$ & ND & \\
\hline & & BAMW16S-W-28624 & $3 / 5 / 09$ & 1.4 & ND & \\
\hline & & BAMW16S-W-28663 & $6 / 18 / 09$ & 1.6 & ND & \\
\hline \multirow{7}{*}{ MW16D } & $90-100$ & BAMW16D-W-22562 & $4 / 4 / 07$ & ND & ND & \\
\hline & & BAMW16D-W-22618 & $11 / 19 / 07$ & ND & ND & \\
\hline & & BAMW16D-W-22633 & $3 / 7 / 08$ & ND & ND & \\
\hline & & BAMW16D-W-22694 & $7 / 11 / 08$ & ND & ND & \\
\hline & & BAMW16D-W-27745 & $10 / 23 / 08$ & ND & ND & \\
\hline & & BAMW16D-W-28625 & $3 / 5 / 09$ & ND & ND & \\
\hline & & BAMW16D-W-28664 & $6 / 18 / 09$ & ND & ND & \\
\hline
\end{tabular}

Pumping Status of Public Wells 
TABLE 4.3 (Cont.)

\begin{tabular}{|c|c|c|c|c|c|c|c|}
\hline \multirow[b]{2}{*}{ Location } & \multirow[b]{2}{*}{$\begin{array}{l}\text { Depth } \\
\text { (ft BGL) }\end{array}$} & \multirow[b]{2}{*}{ Sample } & \multirow[b]{2}{*}{$\begin{array}{l}\text { Sample } \\
\text { Date }\end{array}$} & \multicolumn{3}{|c|}{ Concentration $(\mu \mathrm{g} / \mathrm{L})$} & \multirow[b]{2}{*}{$\begin{array}{l}\text { Pumping Status } \\
\text { of Public Wells }\end{array}$} \\
\hline & & & & $\begin{array}{c}\text { Carbon } \\
\text { Tetrachloride }\end{array}$ & Chloroform & $\begin{array}{l}\text { Methylene } \\
\text { Chloride }\end{array}$ & \\
\hline \multicolumn{8}{|c|}{ CCC/USDA wells installed during the 2006-2007 investigation (cont.) } \\
\hline MW17 & $120-130$ & $\begin{array}{l}\text { BAMW17D-W-22566 } \\
\text { BAMW17D-W-22619 } \\
\text { BAMW17-W-22634 } \\
\text { BAMW17-W-22695 } \\
\text { BAMW17-W-27746 } \\
\text { BAMW17-W-28626 } \\
\text { BAMW17-W-28665 }\end{array}$ & $\begin{array}{r}4 / 4 / 07 \\
11 / 19 / 07 \\
3 / 5 / 08 \\
7 / 9 / 08 \\
10 / 22 / 08 \\
3 / 4 / 09 \\
6 / 17 / 09\end{array}$ & $\begin{array}{l}\text { ND } \\
\text { ND } \\
0.3 \mathrm{~J} \\
0.4 \mathrm{~J} \\
0.7 \mathrm{~J} \\
1.0 \\
1.0\end{array}$ & $\begin{array}{l}\text { ND } \\
\text { ND } \\
\text { ND } \\
\text { ND } \\
\text { ND } \\
\text { ND } \\
\text { ND }\end{array}$ & $\begin{array}{l}\text { ND } \\
\text { ND } \\
\text { ND } \\
\text { ND } \\
\text { ND } \\
\text { ND } \\
\text { ND }\end{array}$ & \\
\hline \multicolumn{8}{|c|}{ Private wells } \\
\hline Oentrich & 150 & $\begin{array}{l}\text { BAOENT-W-21693 } \\
\text { BAOENT-W-21713 } \\
\text { BAOENTRICH-W-22579 } \\
\text { BAOENTRICH-W-22622 } \\
\text { BAOENTRICH-W-22654 } \\
\text { BAOENTRICH-W-22695 } \\
\text { BAOENTRICH-W-27747 } \\
\text { BAOENTRICH-W-28627 } \\
\text { BAOENTRICH-W-28666 }\end{array}$ & $\begin{array}{r}7 / 20 / 06 \\
8 / 2 / 06 \\
4 / 5 / 07 \\
11 / 19 / 07 \\
3 / 6 / 08 \\
7 / 11 / 08 \\
10 / 23 / 08 \\
3 / 5 / 09 \\
6 / 18 / 09\end{array}$ & $\begin{array}{l}0.3 \mathrm{~J} \\
0.6 \mathrm{~J} \\
0.6 \mathrm{~J} \\
0.8 \mathrm{~J} \\
1.3 \\
0.3 \mathrm{~J} \\
0.9 \mathrm{~J} \\
1.1 \\
0.9 \mathrm{~J}\end{array}$ & $\begin{array}{l}\text { ND } \\
\text { ND } \\
\text { ND } \\
\text { ND } \\
\text { ND } \\
\text { ND } \\
\text { ND } \\
\text { ND } \\
\text { ND }\end{array}$ & $\begin{array}{l}\text { ND } \\
\text { ND } \\
\text { ND } \\
\text { ND } \\
\text { ND } \\
\text { ND } \\
\text { ND } \\
\text { ND } \\
\text { ND }\end{array}$ & \\
\hline Sedivy & 138 & $\begin{array}{l}\text { BACW-W-21849 } \\
\text { BASED2-W-21913 }\end{array}$ & $\begin{array}{l}8 / 22 / 06 \\
9 / 13 / 06\end{array}$ & $\begin{array}{l}\text { ND } \\
\text { ND }\end{array}$ & $\begin{array}{l}\text { ND } \\
\text { ND }\end{array}$ & $\begin{array}{l}\text { ND } \\
\text { ND }\end{array}$ & \\
\hline Sedivy1 & 90 & Not sampled (well dry) & $9 / 13 / 06$ & - & - & - & \\
\hline \multicolumn{8}{|c|}{ Public water supply wells } \\
\hline PWS2 & 155 & $\begin{array}{l}\text { BAPWS2-W-22510 } \\
\text { BAPW2-W-22578 } \\
\text { BAPW2-W-22620 } \\
\text { BAPWS2-W-22655 } \\
\text { BAPWS2-W-22696 }\end{array}$ & $\begin{array}{l}3 / 9 / 07 \\
4 / 5 / 07 \\
11 / 20 / 07 \\
3 / 6 / 08 \\
7 / 11 / 08\end{array}$ & $\begin{array}{l}\text { ND } \\
\text { ND } \\
\text { ND } \\
\text { ND } \\
0.8 \mathrm{~J}\end{array}$ & $\begin{array}{l}\text { ND } \\
\text { ND } \\
\text { ND } \\
\text { ND } \\
\text { ND }\end{array}$ & $\begin{array}{l}\text { ND } \\
\text { ND } \\
\text { ND } \\
\text { ND } \\
\text { ND }\end{array}$ & $\begin{array}{l}\text { Well has been pumping today. } \\
\text { Sampled after letting run for } 5-10 \text { min. } \\
\text { Well on at time of sampling. } \\
\text { Let water run from tap for } 2-3 \mathrm{~min} \text {, } \\
\text { then sampled. } \\
\text { Running for } 30 \text { min. }\end{array}$ \\
\hline
\end{tabular}




\begin{tabular}{|c|c|c|c|c|c|c|c|}
\hline \multirow[b]{2}{*}{ Location } & \multirow[b]{2}{*}{$\begin{array}{l}\text { Depth } \\
\text { (ft BGL) }\end{array}$} & \multirow[b]{2}{*}{ Sample } & \multirow[b]{2}{*}{$\begin{array}{l}\text { Sample } \\
\text { Date }\end{array}$} & \multicolumn{3}{|c|}{ Concentration $(\mu \mathrm{g} / \mathrm{L})$} & \multirow[b]{2}{*}{$\begin{array}{l}\text { Pumping Status } \\
\text { of Public Wells }\end{array}$} \\
\hline & & & & $\begin{array}{l}\text { Carbon } \\
\text { Tetrachloride }\end{array}$ & Chloroform & $\begin{array}{c}\text { Methylene } \\
\text { Chloride }\end{array}$ & \\
\hline \multicolumn{8}{|c|}{ Public water supply wells (cont.) } \\
\hline \multirow[t]{3}{*}{ PWS2 } & 155 & BAPW2-W-27748 & $10 / 23 / 08$ & 1.7 & ND & ND & Well was pumping for $5 \mathrm{~min}$. \\
\hline & & BAPWS2-W-28628 & $3 / 5 / 09$ & $0.9 \mathrm{~J}$ & ND & ND & $\begin{array}{l}\text { Well operating to fill water tower prior } \\
\text { to sampling. }\end{array}$ \\
\hline & & BAPWS2-W-28667 & $6 / 18 / 09$ & 1.0 & ND & ND & $\begin{array}{l}\text { Well pumping since } 6 \text { a.m. on June } \\
\text { 18. Let run from tap for } 5 \mathrm{~min} \text {, then } \\
\text { sampled. }\end{array}$ \\
\hline \multirow[t]{9}{*}{ PWS3 } & 160 & BAPWS3-W-22511 & $3 / 9 / 07$ & $0.2 \mathrm{~J}$ & ND & ND & Well has been pumping today. \\
\hline & & BAPW3-W-22577 & $4 / 5 / 07$ & ND & ND & ND & Well has been pumping all day. \\
\hline & & BAPW3-W-22621 & $11 / 20 / 07$ & ND & ND & ND & Well on at time of sampling. \\
\hline & & & & & & & $\begin{array}{l}\text { Sample collected from tap in well } \\
\text { house. Let water run from tap for } 2 \text { - }\end{array}$ \\
\hline & & BAPWS3-W-22656 & 3/6/08 & ND & ND & ND & 3 min, then sampled. \\
\hline & & BAPWS3-W-22697 & $7 / 11 / 08$ & $0.2 \mathrm{~J}$ & ND & ND & Running for $30 \mathrm{~min}$. \\
\hline & & BAPW3-W-27749 & $10 / 23 / 08$ & ND & ND & ND & Well was pumping for $30 \mathrm{~min}$. \\
\hline & & BAPWS3-W-28629 & $3 / 5 / 09$ & ND & ND & ND & Ran for 5 min. \\
\hline & & BAPWS3-W-28668 & $6 / 18 / 09$ & ND & ND & ND & $\begin{array}{l}\text { Well was used on June } 17 . \text { Let pump } \\
\text { run for } 10 \mathrm{~min} \text {, then sampled. }\end{array}$ \\
\hline
\end{tabular}

a ND, contaminant not detected at an instrument detection limit of $0.1 \mu \mathrm{g} / \mathrm{L}$.

b Qualifier J indicates an estimated concentration below the purge-and-trap method quantitation limit of $1.0 \mu \mathrm{g} / \mathrm{L}$. 


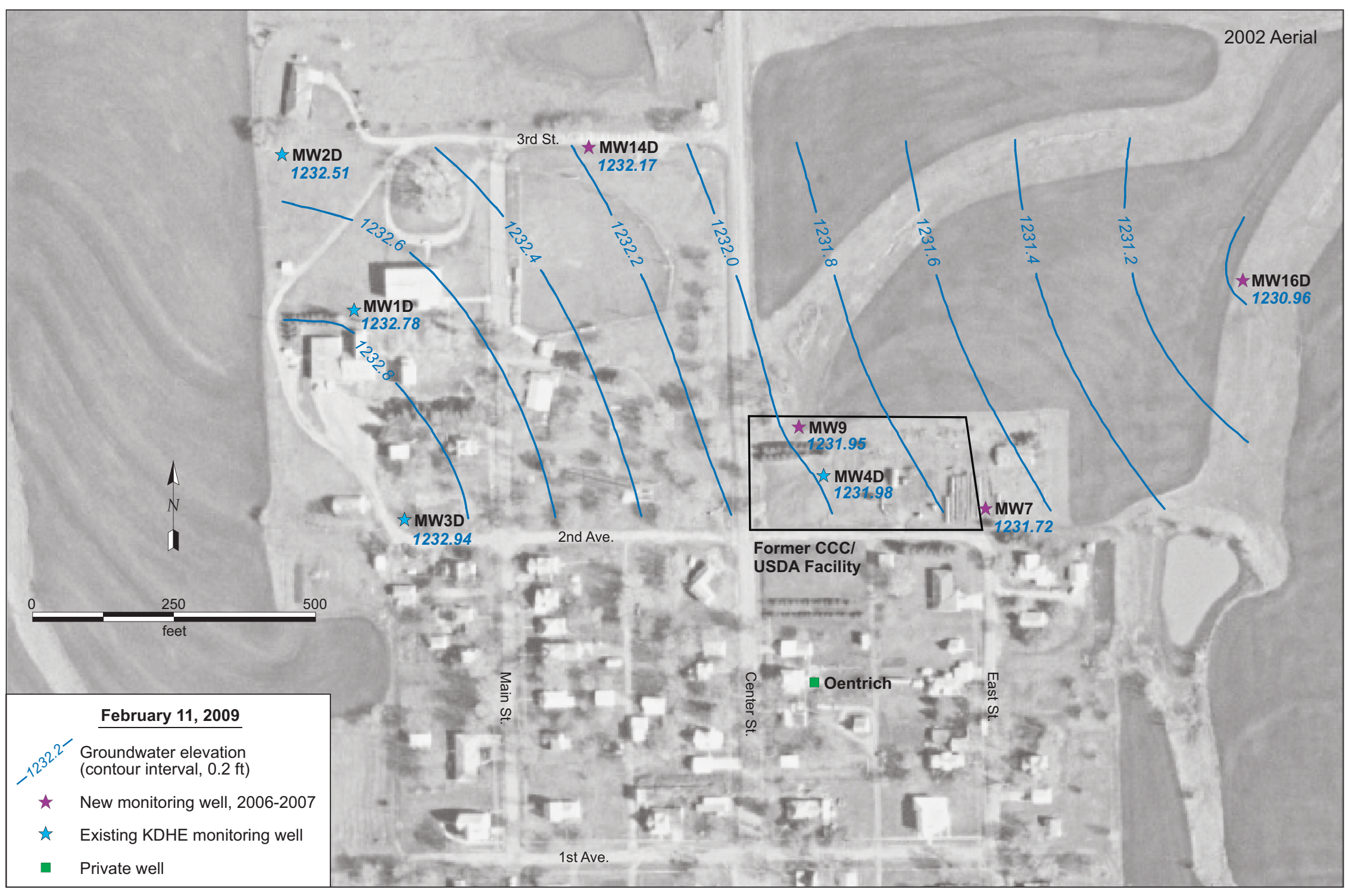

FIGURE 4.1a Potentiometric surface map depicting the groundwater flow direction in the deeper aquifer zone at Barnes under static (nonpumping) conditions on February 11, 2009. Source of photograph: NAPP (2002). 


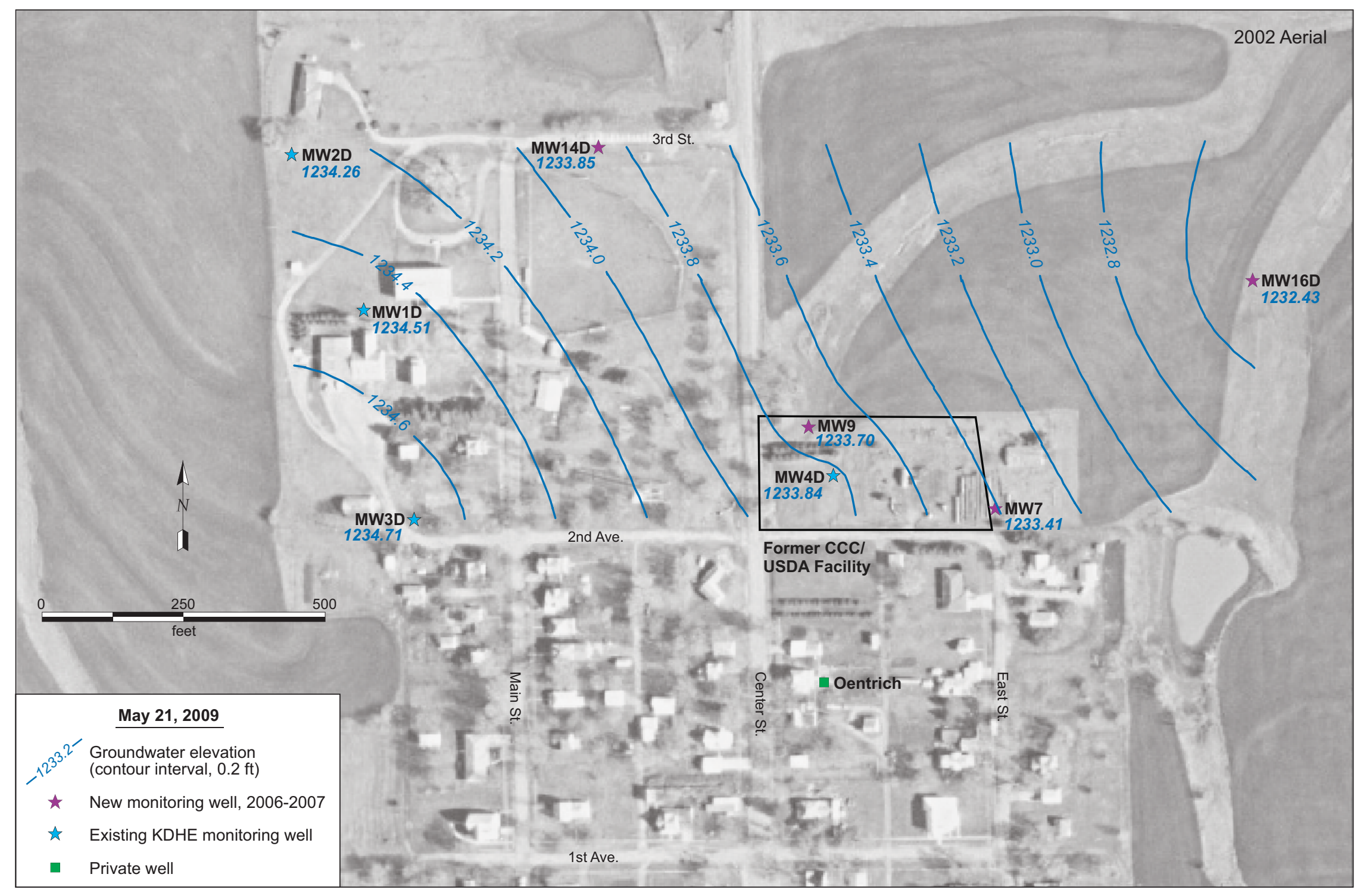

FIGURE 4.1b Potentiometric surface map depicting the groundwater flow direction in the deeper aquifer zone at Barnes under static (non-pumping) conditions on May 21, 2009. Source of photograph: NAPP (2002). 

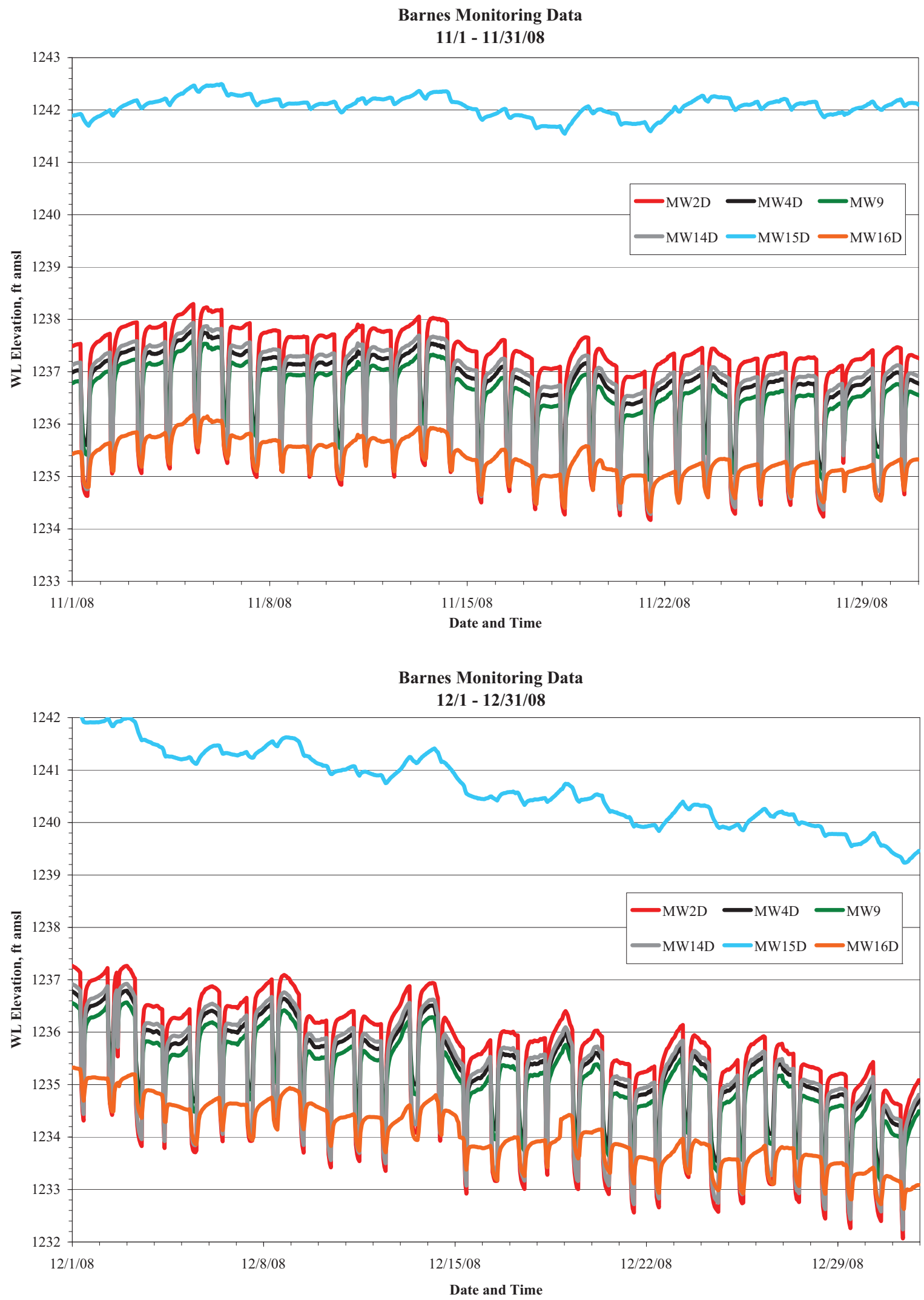

FIGURE 4.2a Hydrographs summarizing monthly results of long-term water level monitoring in the deep-zone wells at Barnes, November 2008 to May 2009. 
Barnes Monitoring Data

1/1 - 1/31/09

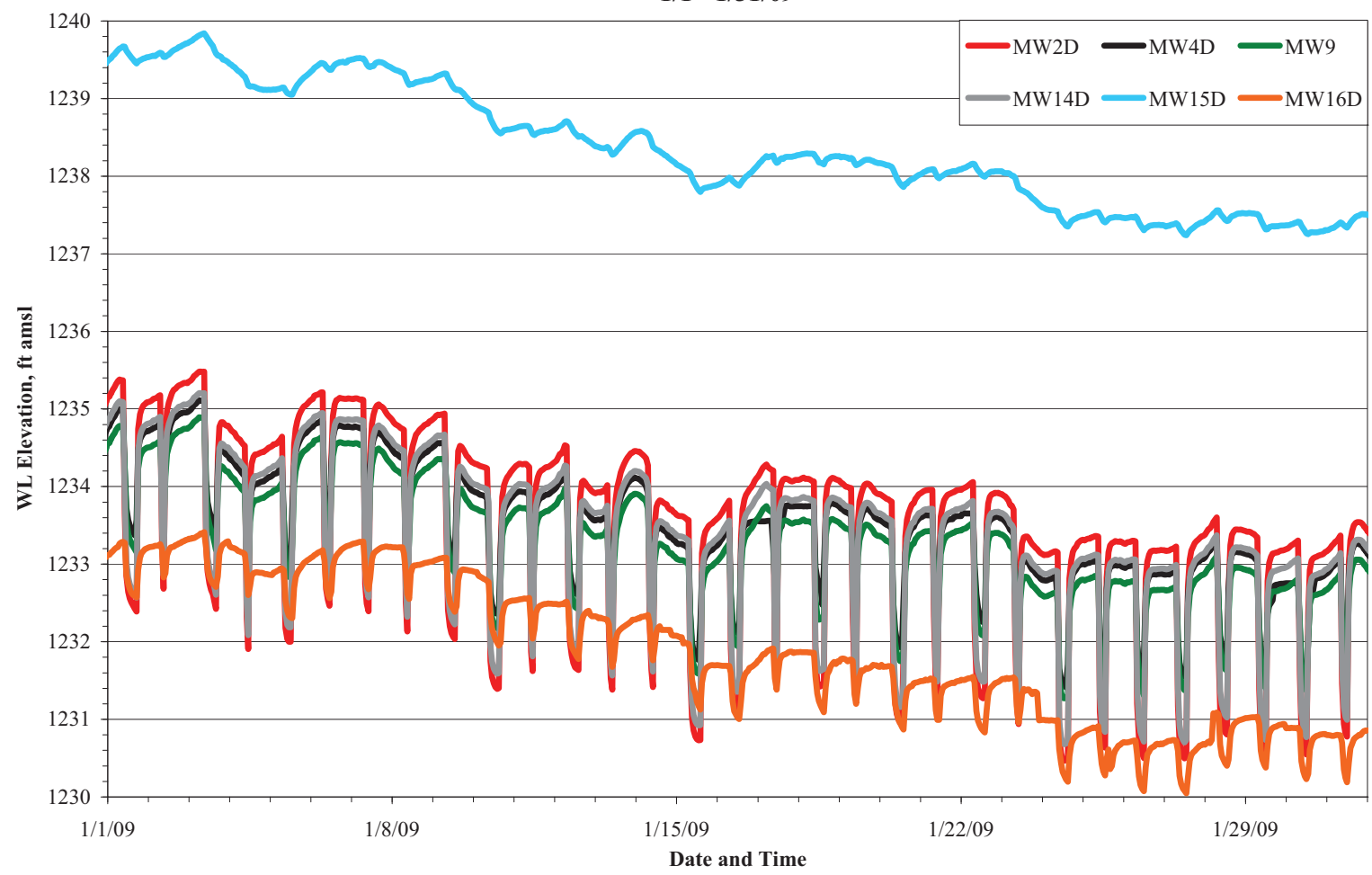

Barnes Monitoring Data

2/1 - 2/28/09

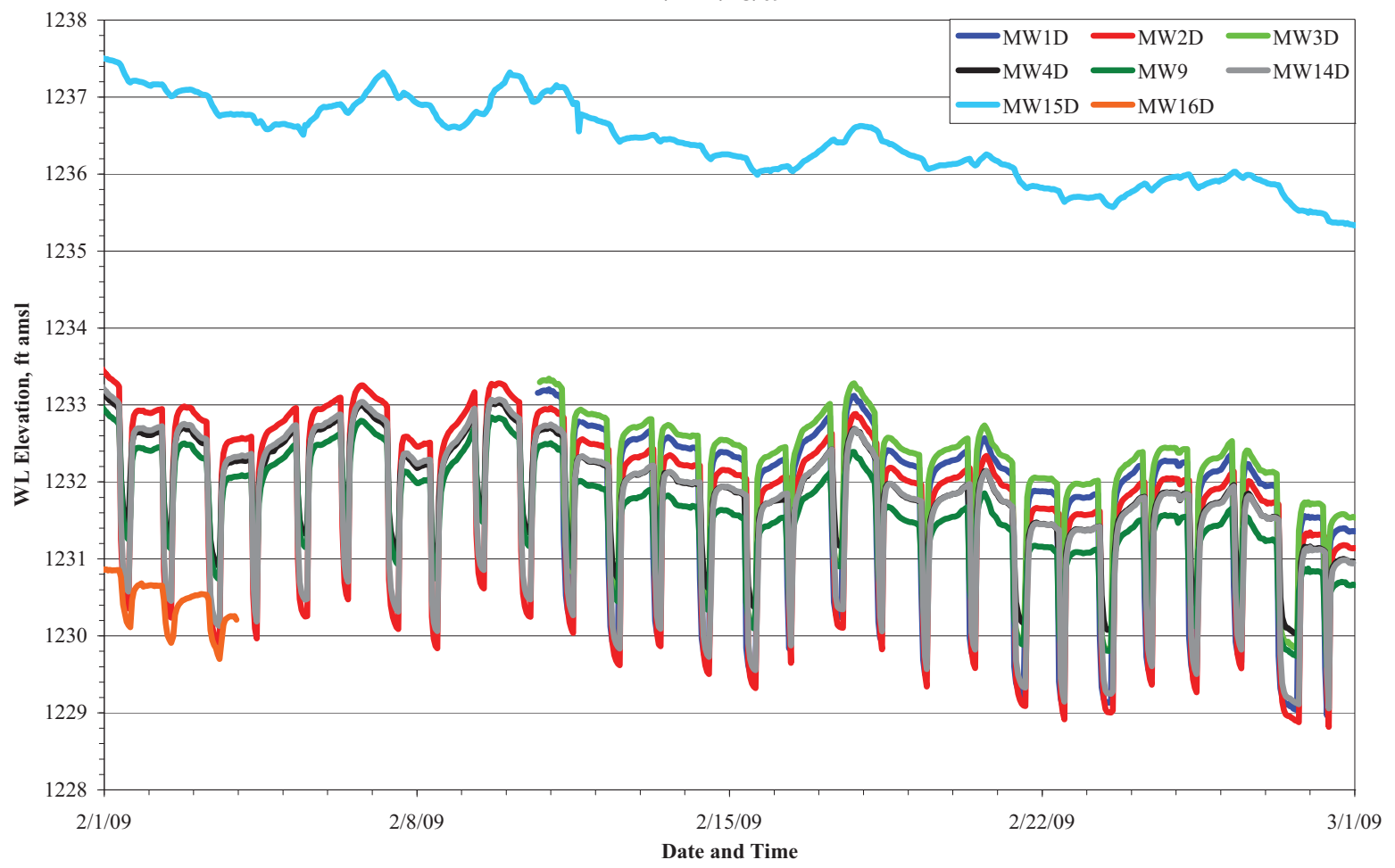

FIGURE 4.2a (Cont.) 

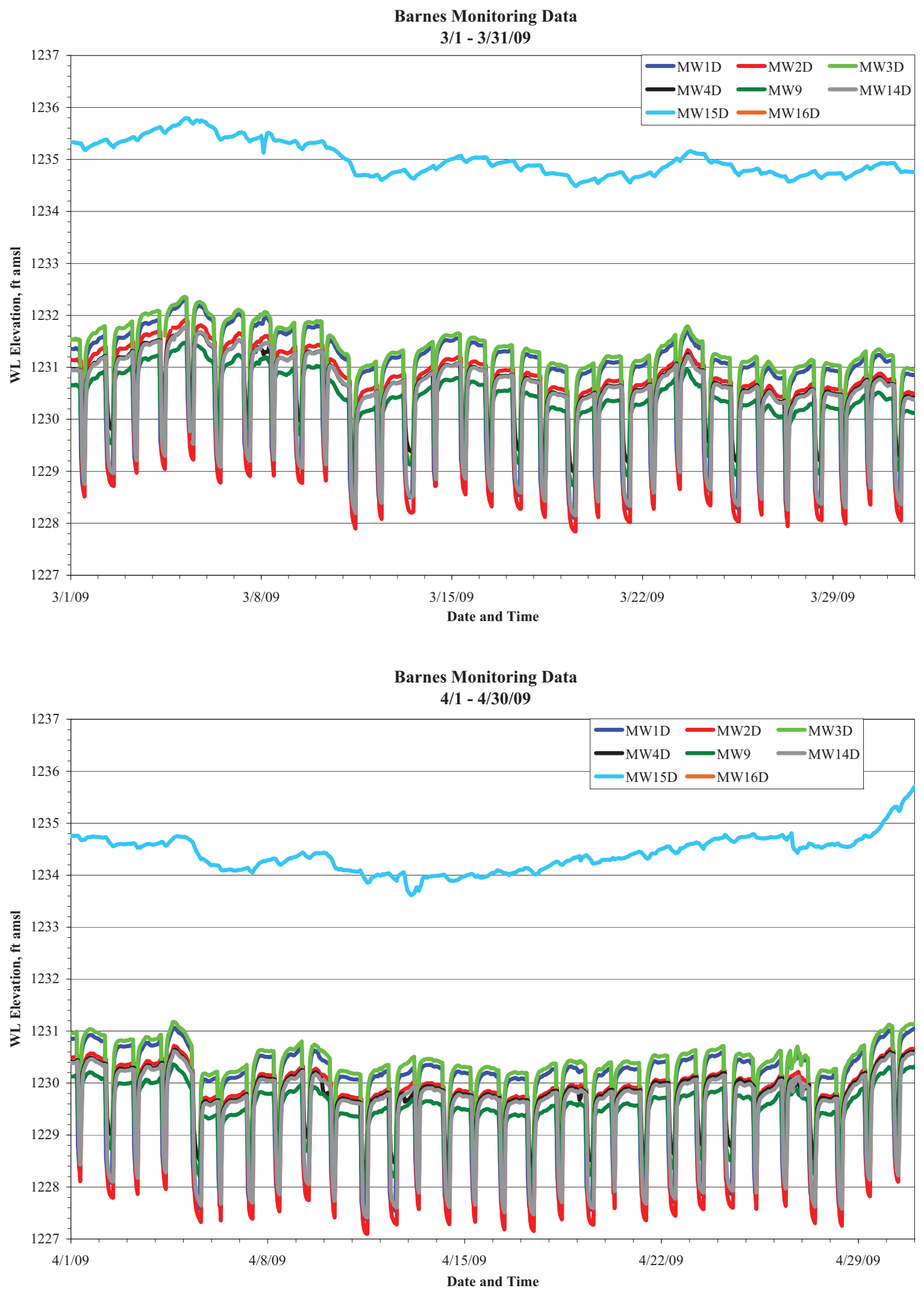

FIGURE 4.2a (Cont.) 


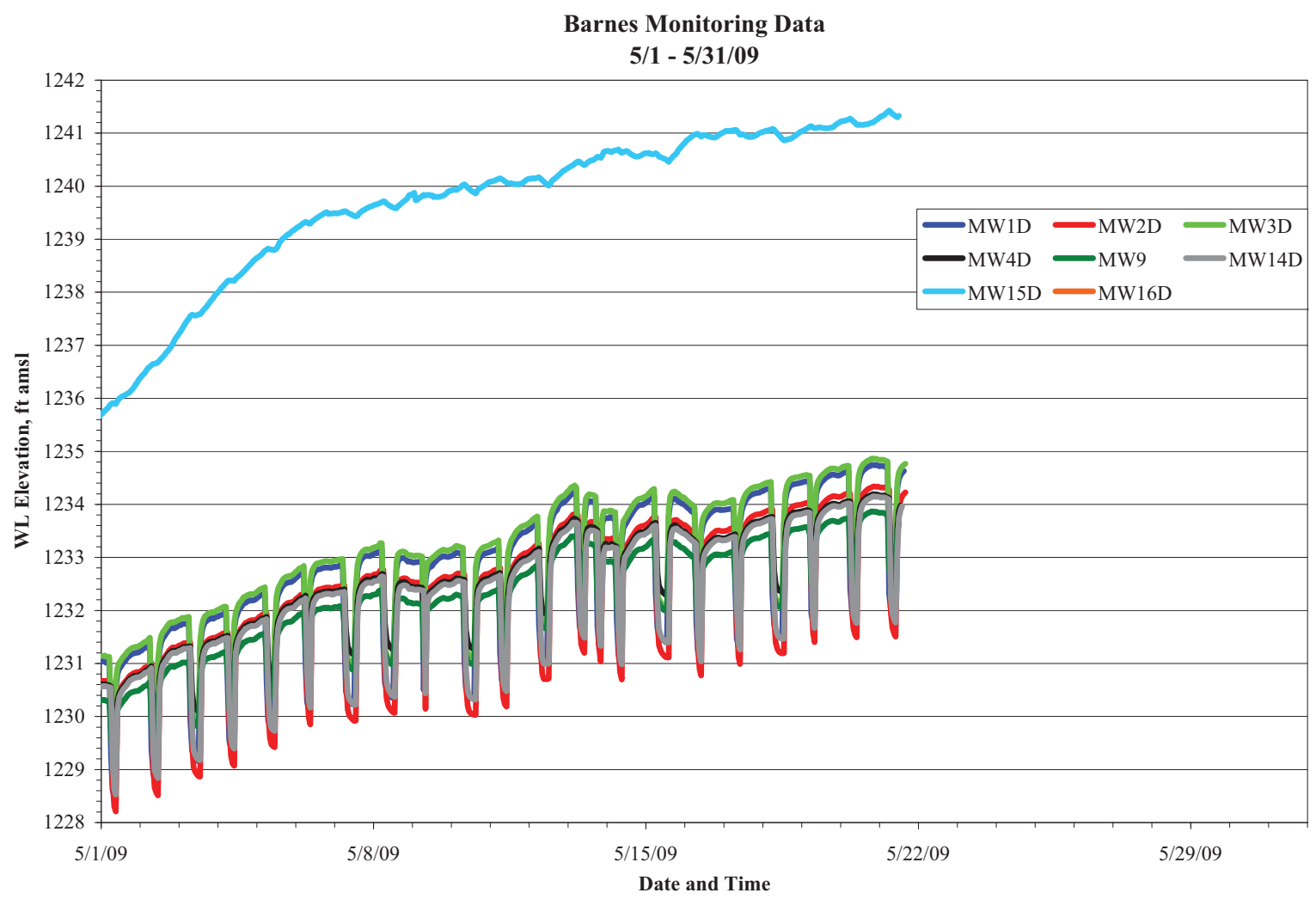

FIGURE 4.2a (Cont.) 
Barnes Monitoring Data

11/1 - 11/31/08

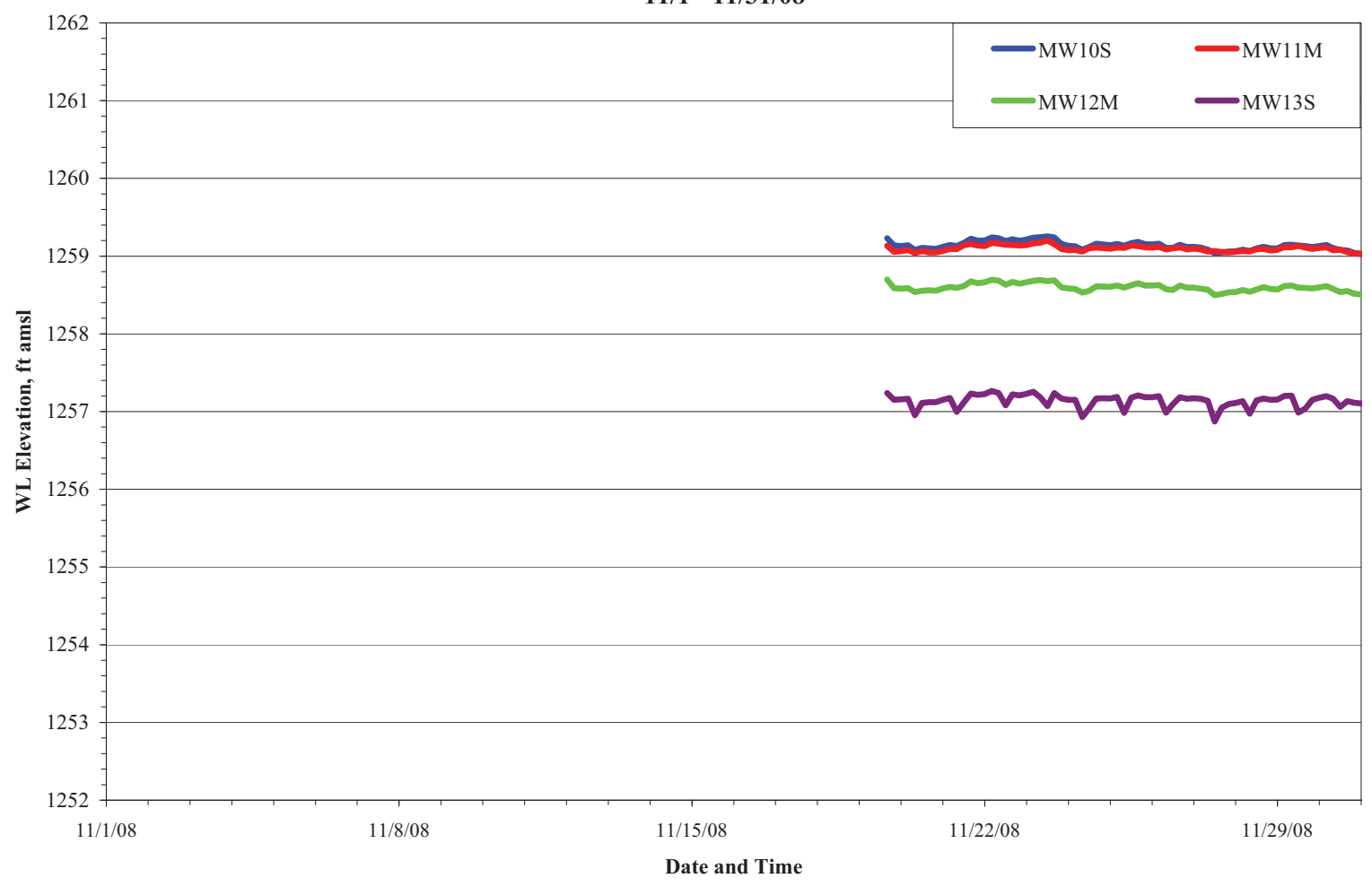

Barnes Monitoring Data

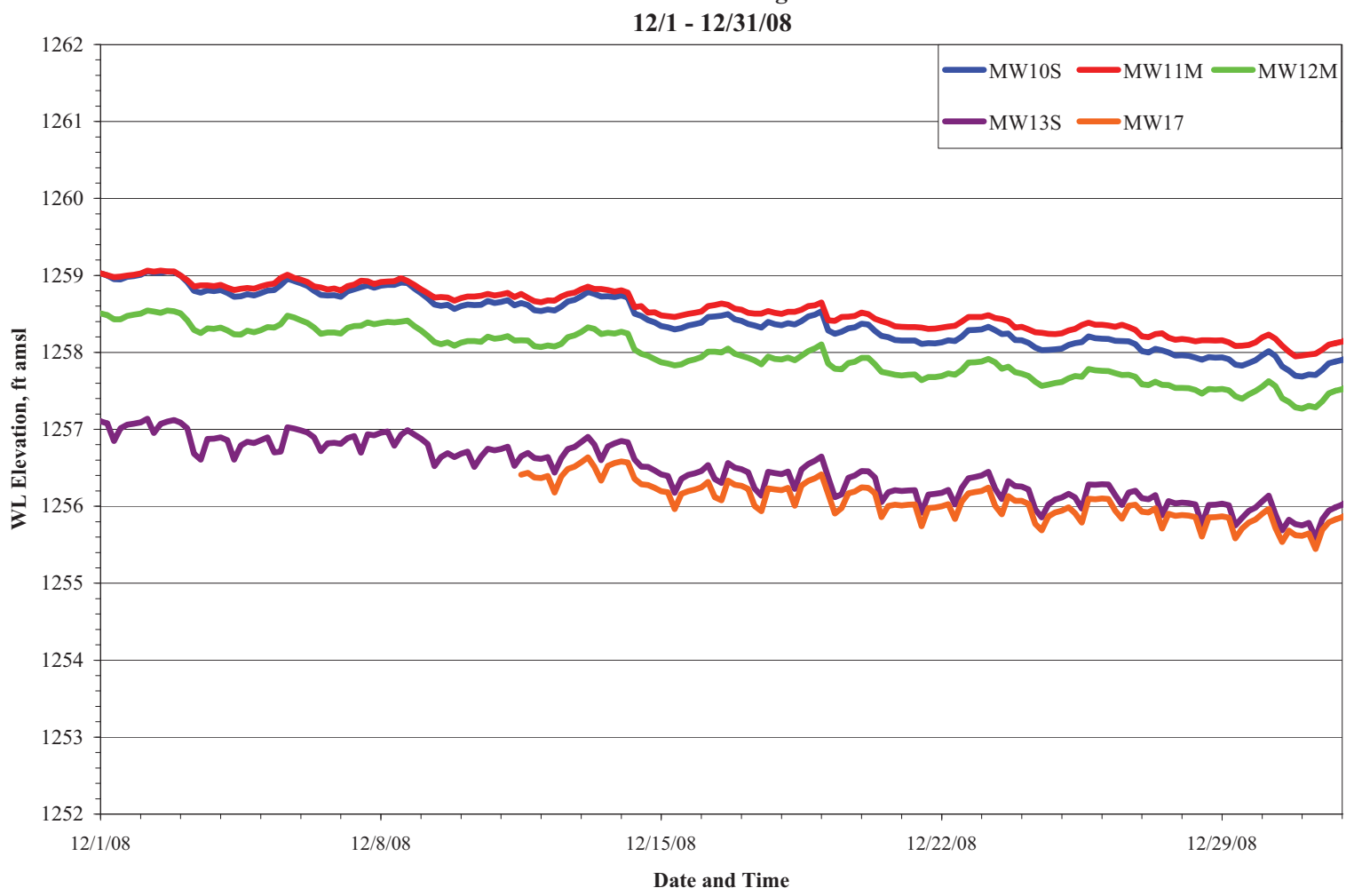

FIGURE 4.2b Hydrographs summarizing monthly results of long-term water level monitoring in the intermediate-zone wells at Barnes, November 2008 to May 2009. 
Barnes Monitoring Data

1/1 - 1/31/09

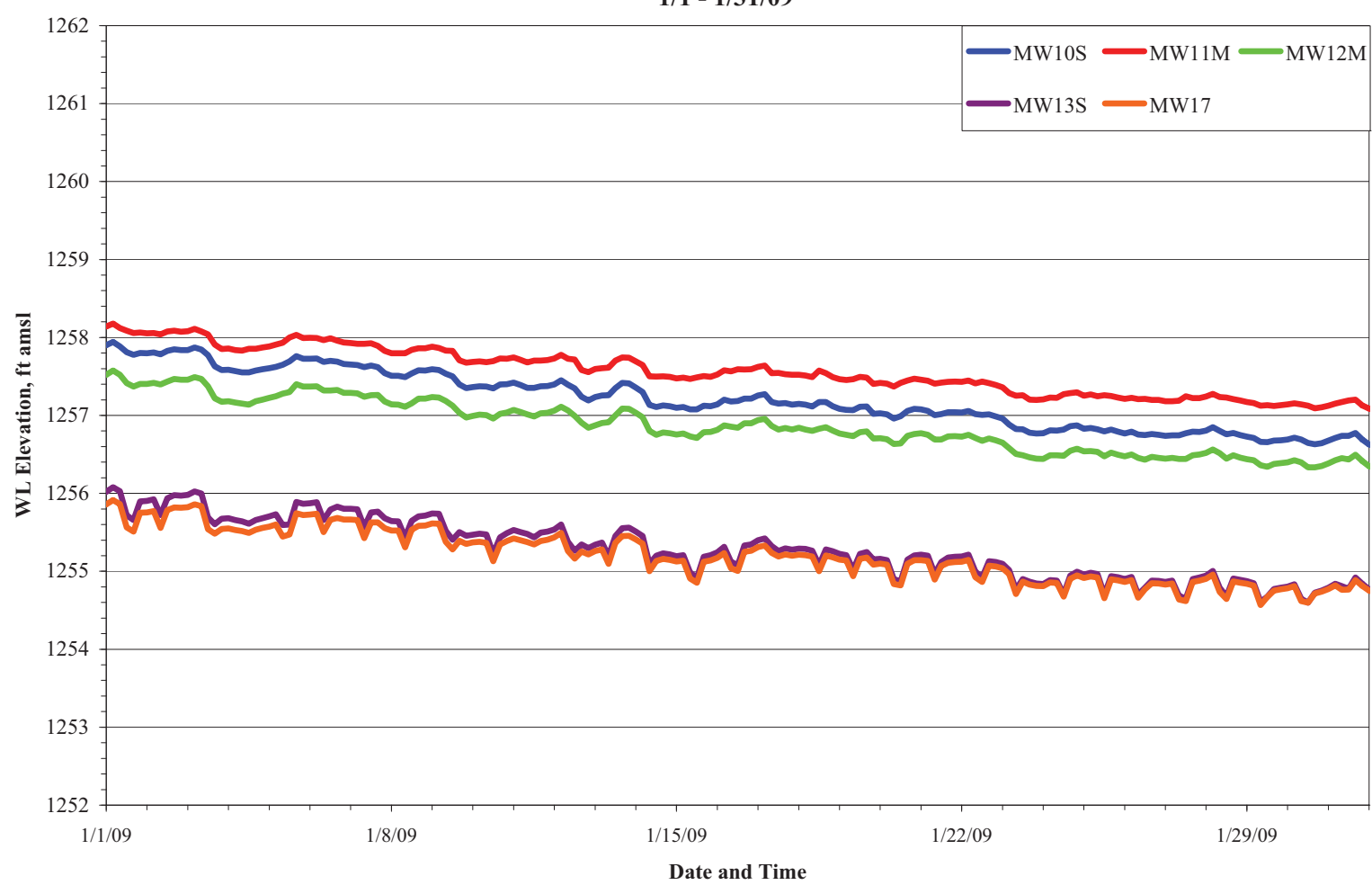

Barnes Monitoring Data

$2 / 1-2 / 28 / 09$

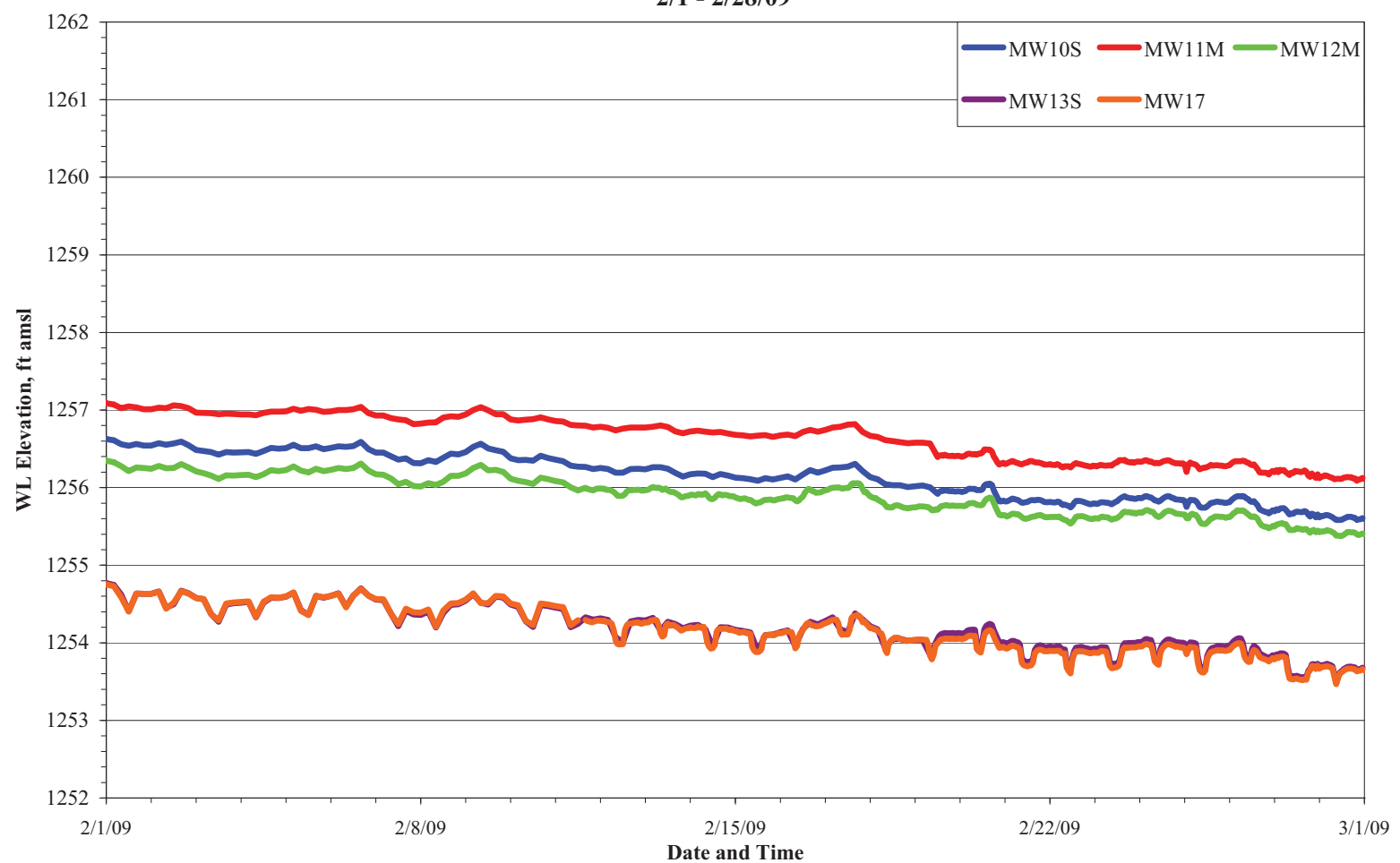

FIGURE 4.2b (Cont.) 
Barnes Monitoring Data

3/1 - 3/31/09

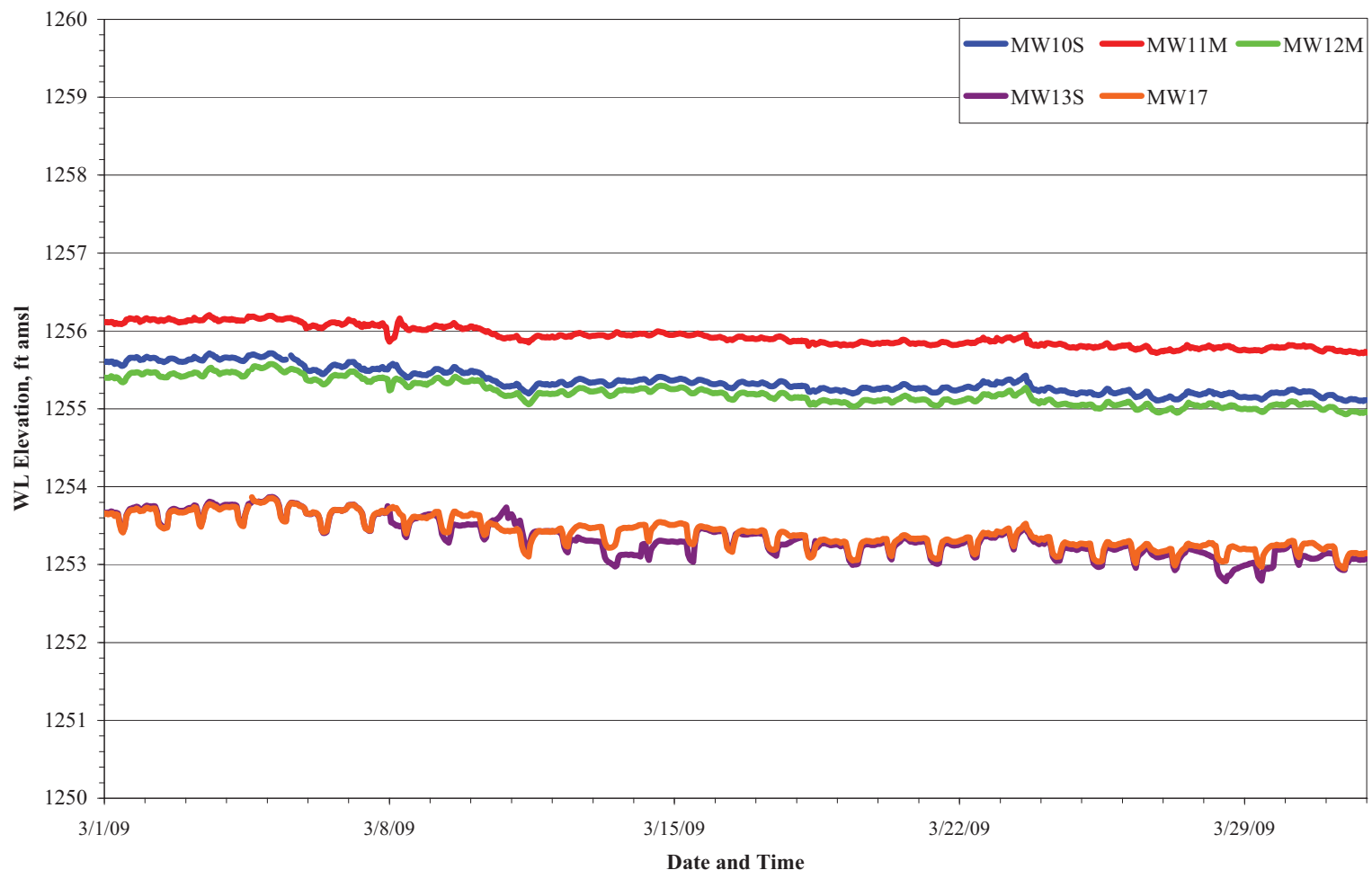

Barnes Monitoring Data

4/1 - 4/30/09

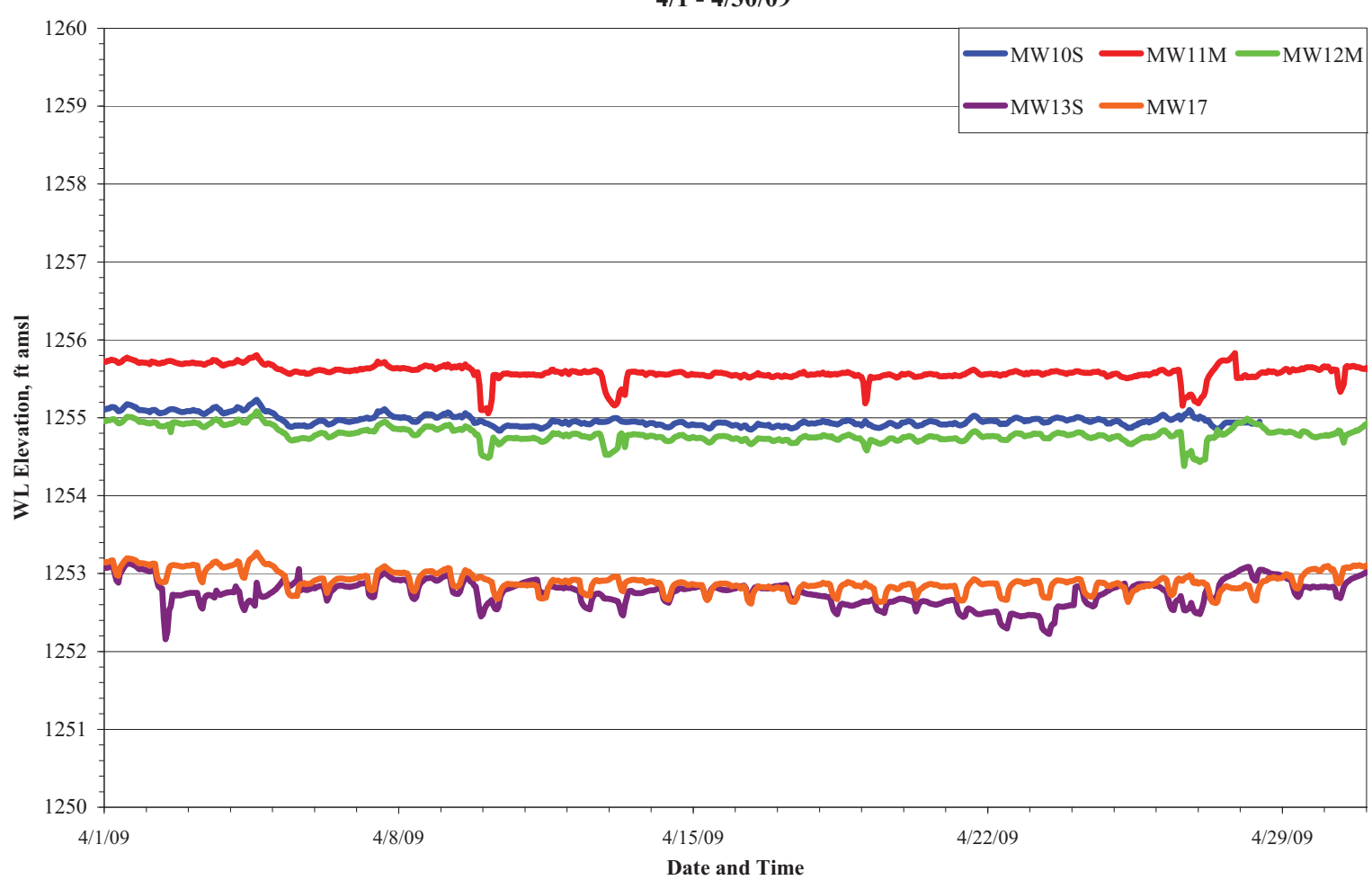

FIGURE 4.2b (Cont.) 


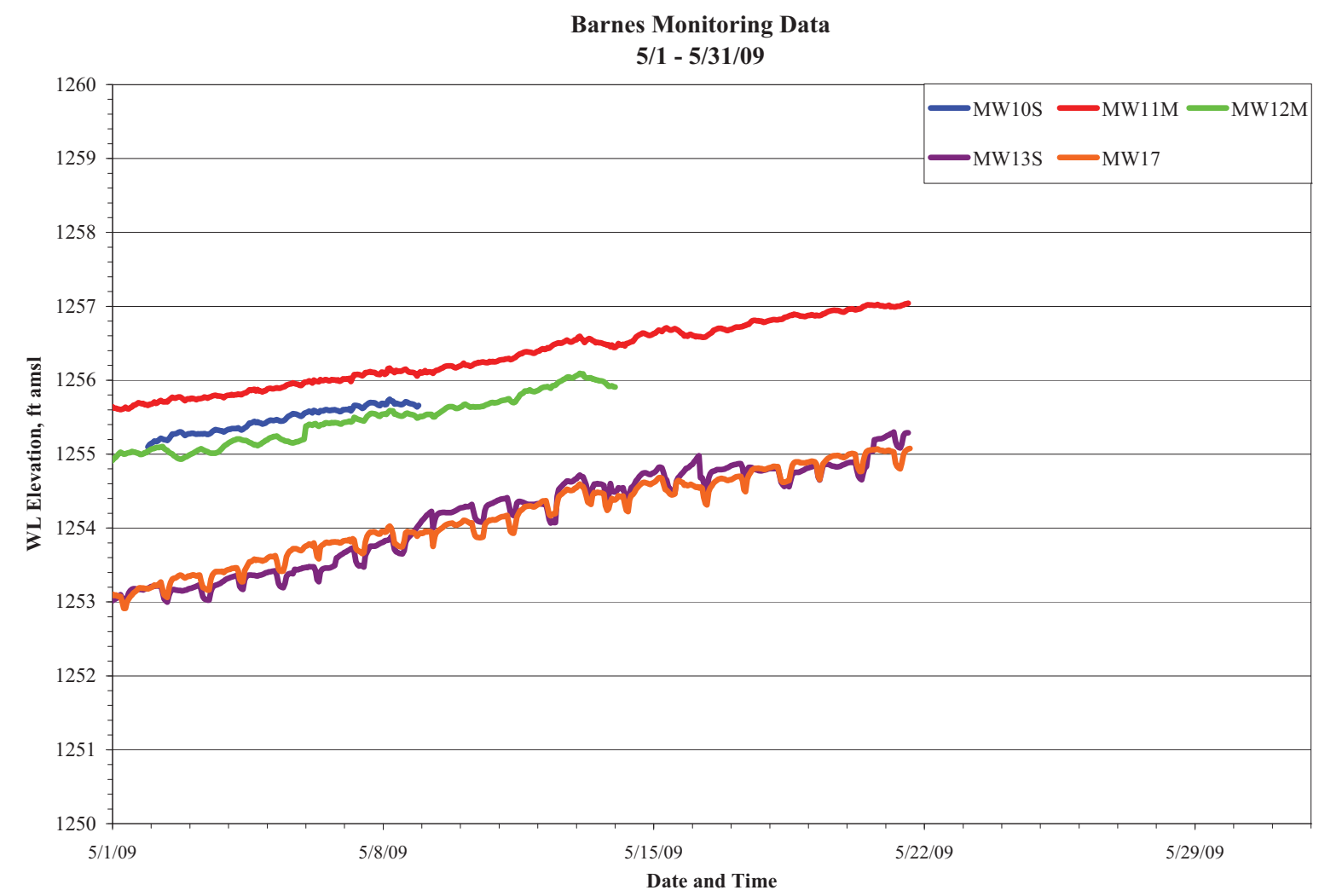

FIGURE 4.2b (Cont.) 


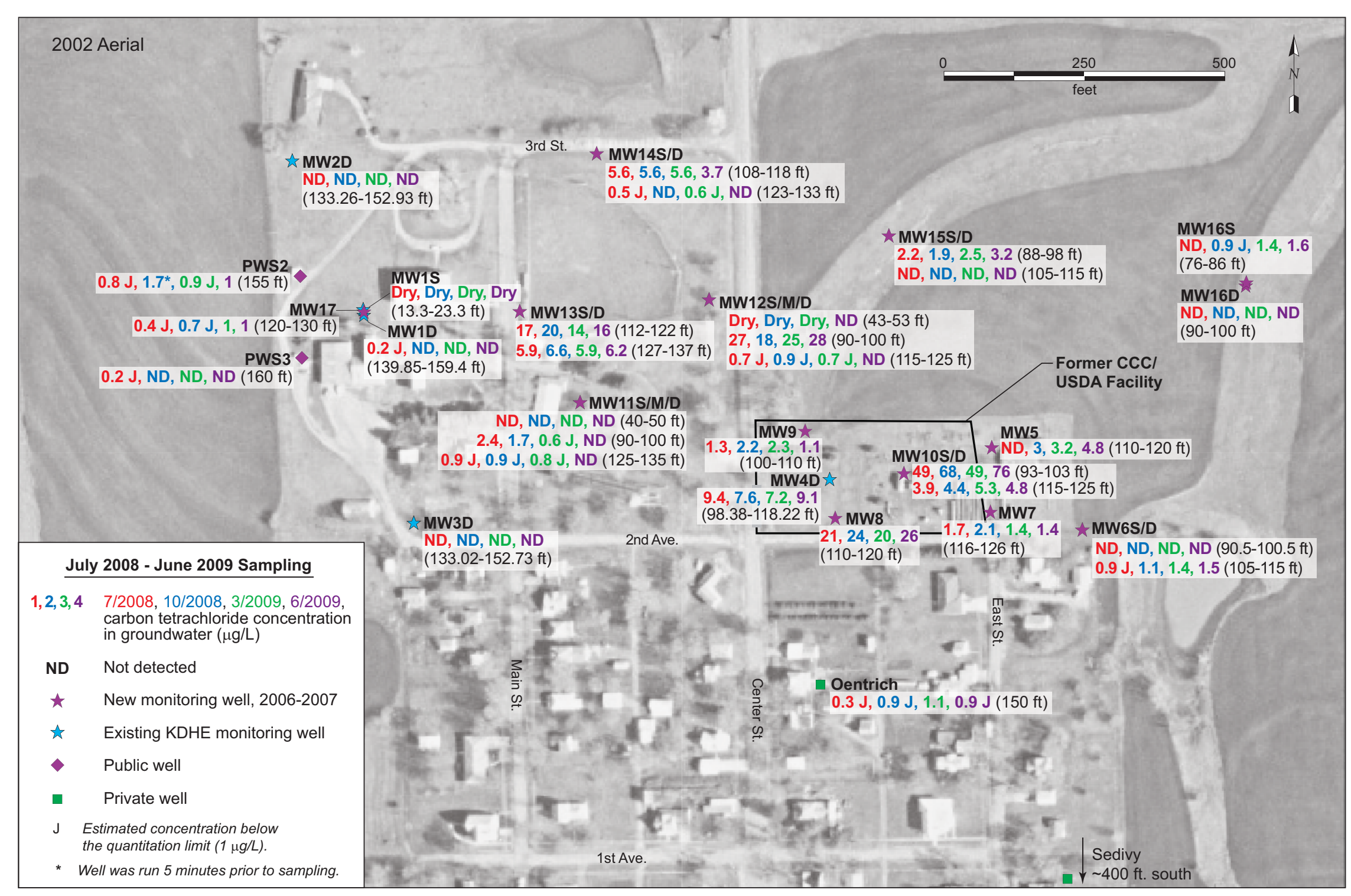

FIGURE 4.3 Analytical results for carbon tetrachloride in groundwater samples collected at Barnes in July 2008 to June 2009. Source of photograph: NAPP (2002). 


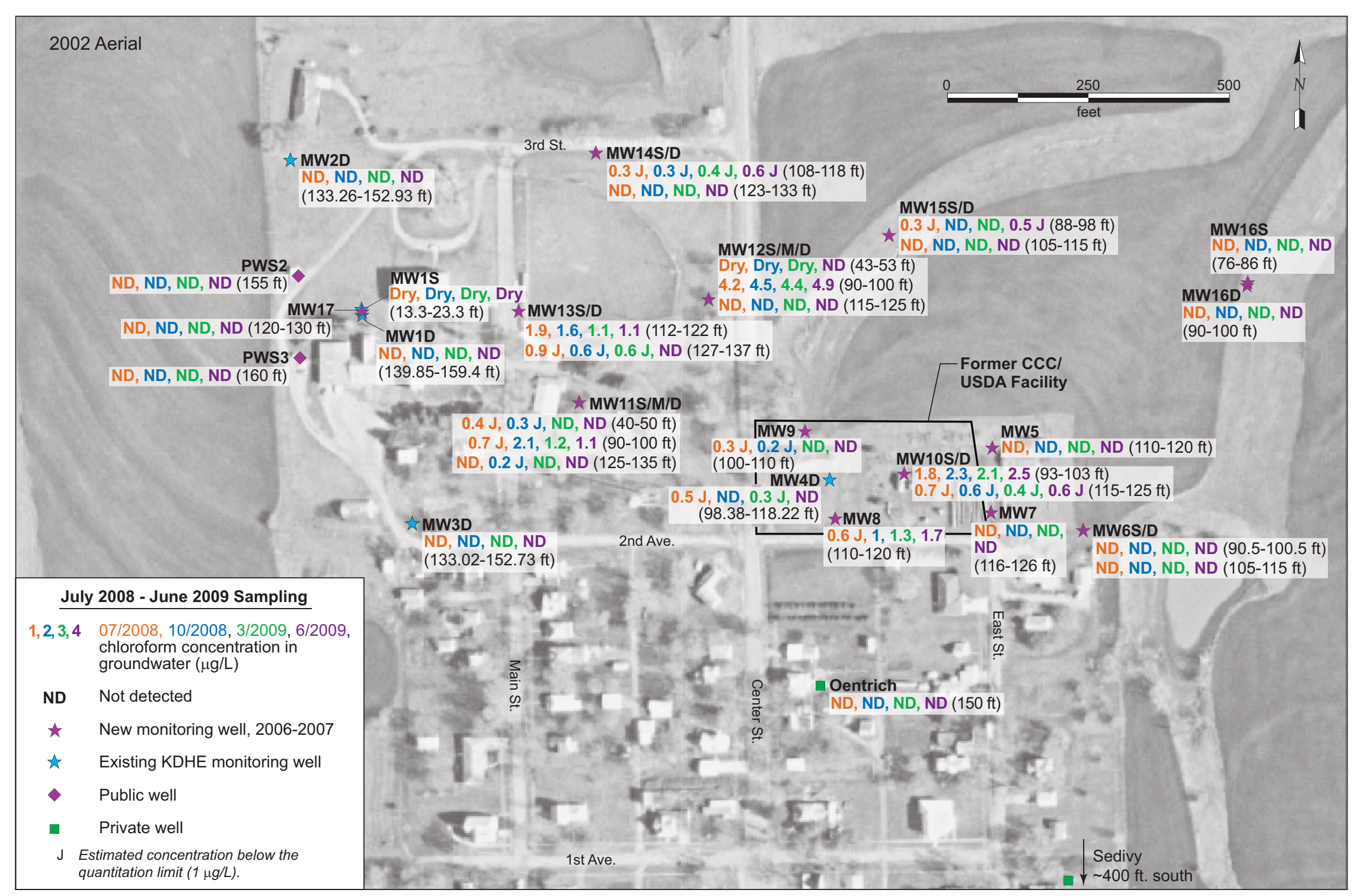

FIGURE 4.4 Analytical results for chloroform in groundwater samples collected at Barnes in July 2008 to June 2009. Source of photograph: NAPP (2002). 


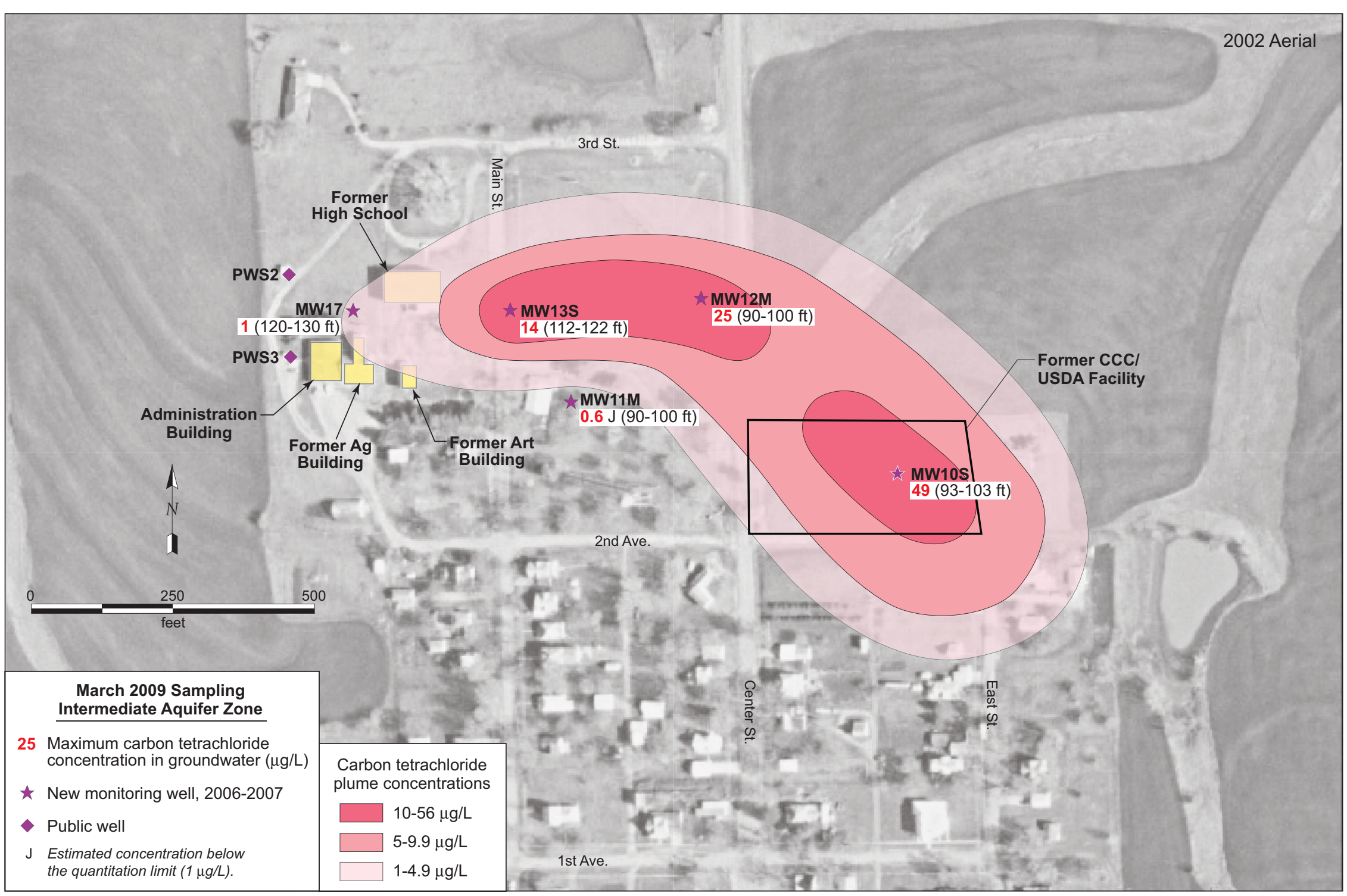

FIGURE 4.5 Interpreted carbon tetrachloride plume in March 2009 in wells screened in the intermediate aquifer zone (groundwater levels approximately 1,251-1,256 ft AMSL). Source of photograph: NAPP (2002). 


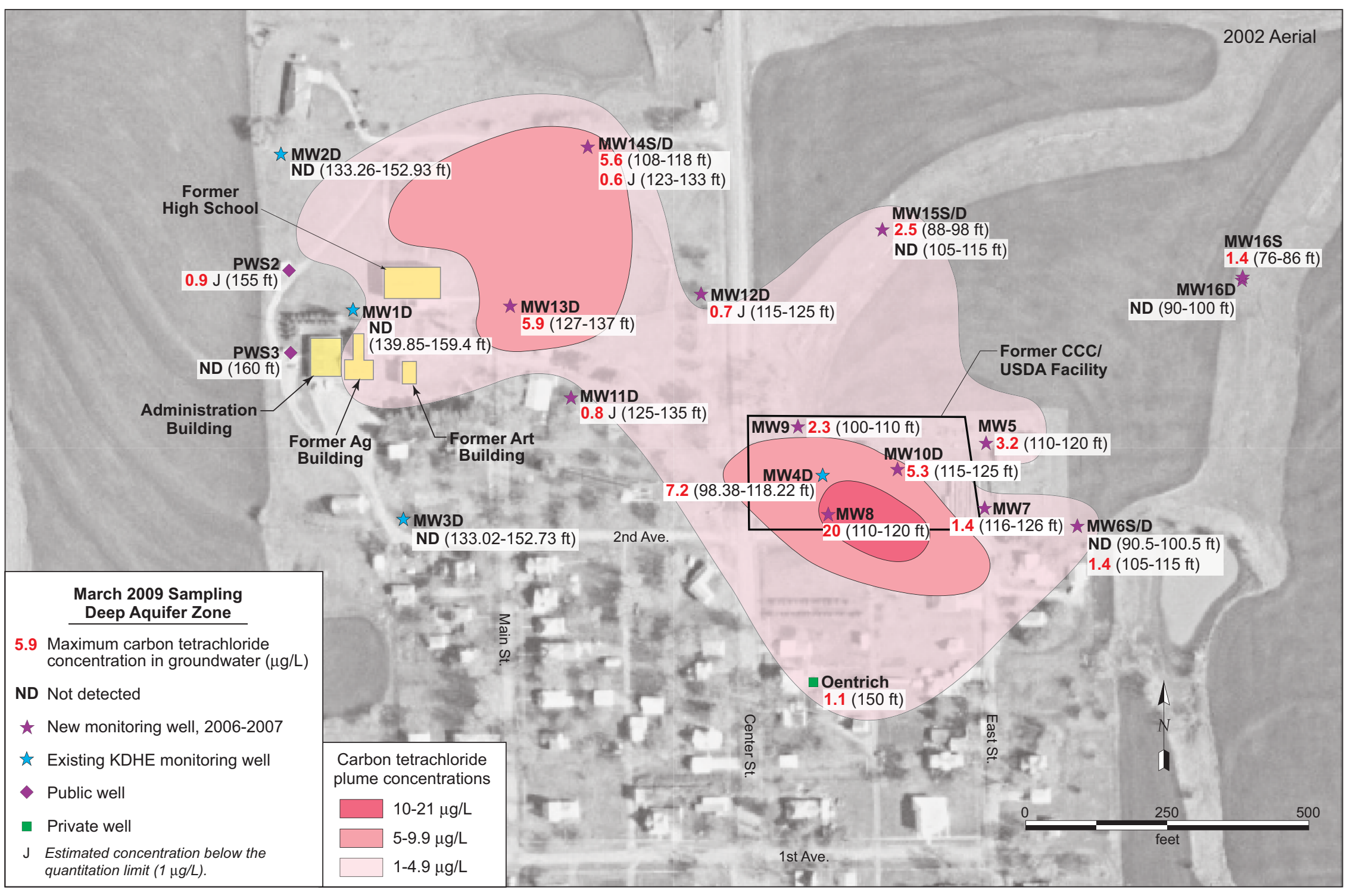

FIGURE 4.6 Interpreted carbon tetrachloride plume in March 2009 in wells screened in the deep aquifer zone (groundwater levels approximately 1,230-1,236 ft AMSL). Source of photograph: NAPP (2002). 


\section{Conclusions, Ongoing Tasks, and Recommendations}

\subsection{Conclusions}

The findings of the March and June 2009 monitoring events at Barnes support the following conclusions:

- Measurements of groundwater levels obtained manually and through the use of automatic recorders have consistently indicated that the flow direction is strongly influenced by pumping of the public water supply wells. The results have demonstrated

- An apparent groundwater flow direction to the northeast when the public wells are not pumping and

- A northwesterly groundwater flow trend when the public wells are pumping.

- Evaluation of manual water level measurements and carbon tetrachloride concentrations continues to suggest that three vertically distinguishable aquifer zones are present at Barnes: shallow, intermediate, and deep. As of November 2008, all 5 monitoring wells screened in the intermediate aquifer zone and 9 of 20 wells completed in the deep aquifer zone are monitored with automatic water level recorders. Additional recorders will be added as warranted.

- The vertical distribution of the carbon tetrachloride in groundwater continues to indicate that the highest concentrations occur in the intermediate aquifer zone. Lower concentrations have been detected in the deep aquifer zone, and no carbon tetrachloride has been detected in the shallow zone.

- The conceptual model of the groundwater flow system at Barnes, postulated on the basis of the accumulated results, suggests that the observed vertical hydraulic gradients and higher carbon tetrachloride concentrations in the 
intermediate zone might reflect generally lower permeability and hence less effective groundwater and contaminant migration in the intermediate zone than in the deep aquifer zone.

- Use of the low-flow sampling method during the five monitoring events from March 2008 to June 2009 indicated that the maximum concentration of carbon tetrachloride identified in sitewide monitoring has consistently been detected in intermediate-zone well MW10S, located in the eastern portion of the former CCC/USDA facility.

- Overall, the lateral distribution of carbon tetrachloride in groundwater in March and June 2009 is similar to the distribution during previous sampling events. The most significant change is the decrease in the concentration of carbon tetrachloride in public well PWS2 (from $1.7 \mu \mathrm{g} / \mathrm{L}$ in October 2008 to $<1 \mu \mathrm{g} / \mathrm{L}$ in March 2009 and to $1.0 \mu \mathrm{g} / \mathrm{L}$ in June 2009). No contamination was detected in public well PWS3.

\subsection{Ongoing Tasks}

Ongoing tasks related to Barnes are as follows:

- Automatic water level recorders installed in selected wells across the investigation area are continuing to provide critical data needed to evaluate the hydrologic regime in anticipation of a corrective action study.

- In cooperation with the city, daily pumping rates are being recorded over a short time period to provide information for further evaluation of the aquifer characteristics. When this additional information is available, an attempt will be made to model the effects of the pumping (including rates and frequency) on the distribution of carbon tetrachloride in the subsurface. This effort is expected to include estimation of the capture zone for the pumping public water supply wells. The exact value of the effort will be predicated on the accuracy and level of detail of data provided by the city of Barnes for use in the modeling. 
- A conceptual contingent interim measure work plan is in place for the use of granular activated carbon system for protection of the public water supply wells (KDHE 2009).

\subsection{Recommendations}

- In monitoring since 1986 (23 years) by the City of Barnes, carbon tetrachloride concentrations in the public wells have never been at or above the MCL. Furthermore, the CCC/USDA-Argonne quarterly sitewide monitoring (6 events over 20 months from November 2007 to June 2009) has demonstrated no carbon tetrachloride concentrations at or above the MCL, in the public wells or in nearby monitoring wells. A reduction in the frequency of monitoring from quarterly to annual is therefore recommended. This recommendation is consistent with the following (directly quoted) provisions of 40 CFR 141.24 (f)(11):

(11) If a contaminant listed in $\S 141.61$ (a) (2) through (21) is detected at a level exceeding $0.0005 \mathrm{mg} / \mathrm{l}$ in any sample, then:

(i) The system must monitor quarterly at each sampling point which resulted in a detection.

(ii) The State may decrease the quarterly monitoring requirement specified in paragraph (f)(11)(i) of this section provided it has determined that the system is reliably and consistently below the maximum contaminant level. In no case shall the State make this determination unless a groundwater system takes a minimum of two quarterly samples and a surface water system takes a minimum of four quarterly samples.

(iii) If the State determines that the system is reliably and consistently below the MCL, the State may allow the system to monitor annually. Systems which monitor annually must monitor during the quarter(s) which previously yielded the highest analytical result.

- The CCC/USDA will seek to coordinate its annual sampling of the public wells with the annual sampling schedule of the City of Barnes, so that the public wells are, in fact, sampled twice yearly at intervals of approximately six months. 


\section{References}

Argonne, 2002, Final Master Work Plan: Environmental Investigations at Former CCC/USDA Facilities in Kansas, 2002 Revision, ANL/ER/TR-02/004, prepared for the Commodity Credit Corporation, U.S. Department of Agriculture, Washington, D.C., by Argonne National Laboratory, Argonne, Illinois, December.

Argonne, 2008a, Final Report: Results of the 2006-2007 Investigation of Potential Contamination at the Former CCC/USDA facility in Barnes, Kansas, ANL/EVS/AGEM/TR-0712, prepared for the Commodity Credit Corporation, U.S. Department of Agriculture, Washington, D.C., by Argonne National Laboratory, Argonne, Illinois, August.

Argonne, 2008b, November 2007 Monitoring Results for Barnes, Kansas, ANL/EVS/AGEM/TR-08-04, prepared for the Commodity Credit Corporation, U.S. Department of Agriculture, Washington, D.C., by Argonne National Laboratory, Argonne, Illinois, February.

Argonne, 2008c, March 2008 Monitoring Results for Barnes, Kansas, ANL/EVS/AGEM/TR-0811, prepared for the Commodity Credit Corporation, U.S. Department of Agriculture, Washington, D.C., by Argonne National Laboratory, Argonne, Illinois, August.

Argonne, 2008d, July 2008 Monitoring Results for Barnes, Kansas, ANL/EVS/AGEM/TR-0817, prepared for the Commodity Credit Corporation, U.S. Department of Agriculture, Washington, D.C., by Argonne National Laboratory, Argonne, Illinois, September.

Argonne, 2009, October 2008 Monitoring Results for Barnes, Kansas, ANL/EVS/AGEM/TR09-04, prepared for the Commodity Credit Corporation, U.S. Department of Agriculture, Washington, D.C., by Argonne National Laboratory, Argonne, Illinois, February.

EPA, 1995, Method 524.2: Measurement of Purgeable Organic Compounds in Water by Capillary Column Gas Chromatography/Mass Spectrometry, Revision 4.1, edited by J.W. Munch, National Exposure Research Laboratory, Office of Research and Development, U.S. Environmental Protection Agency, Cincinnati, Ohio.

KDHE, 2009, letter from B. Finzer (Bureau of Environmental Remediation, Kansas Department of Health and Environment, Topeka, Kansas) to C. Roe (Commodity Credit Corporation, 
U.S. Department of Agriculture, Washington, D.C.), regarding Contingency Interim Measure for the Public Water Supply at Barnes, Kansas, April 23.

NAPP, 2002, aerial image NAPP 12897 222, National Aerial Photography Program, U.S. Geological Survey (available from Kansas Geospatial Community Commons [http://www.kansasgis.org/]), April 9.

Puls, R.W., and M.J. Barcelona, 1996, "Low-Flow (Minimal Drawdown) Ground-Water Sampling Procedures," EPA/540/S-95/504, in Ground Water Issue, Superfund Technology Support Center for Ground Water, National Risk Management Research Laboratory, U.S. Environmental Protection Agency, Ada, Oklahoma, April (www.epa.gov/tio/tsp/download/ lwflw2a.pdf).

Yeskis, D., and B. Zavala, 2002, Ground-Water Sampling Guidelines for Superfund and RCRA Project Managers: Ground Water Forum Issue Paper, EPA 542-S-02-001, Technology Innovative Office, Office of Solid Waste and Emergency Response, U.S. Environmental Protection Agency, Washington, D.C., May (http://www.epa.gov/tio/tsp/download/ gw_sampling_guide.pdf). 


\section{Appendix A:}

Sampling Activities and Field Measurements at Barnes in March and June 2009 
TABLE A.1 Sequence of sampling activities at Barnes in March and June 2009. ${ }^{a}$

\begin{tabular}{|c|c|c|c|c|c|c|c|c|}
\hline $\begin{array}{c}\text { Sample } \\
\text { Date }\end{array}$ & Time & Sample & Type $^{b}$ & Location & $\begin{array}{l}\text { Depthc } \\
\text { (ft BGL) }\end{array}$ & $\begin{array}{l}\text { Chain of } \\
\text { Custody }\end{array}$ & $\begin{array}{c}\text { Shipment } \\
\text { Date }\end{array}$ & Sample Description \\
\hline
\end{tabular}

March 2009 sampling

\begin{tabular}{|c|c|c|c|c|c|c|}
\hline $3 / 4 / 09$ & $10: 30$ & BAMW3D-W-22705 & MW & MW3D & $133.02-152.73$ & 6160 \\
\hline $\begin{array}{l}3 / 4 / 09 \\
3 / 4 / 09\end{array}$ & $\begin{array}{l}10: 31 \\
10: 49\end{array}$ & $\begin{array}{l}\text { BAMW3DDUP-W-28632 } \\
\text { BAMW11S-W-22715 }\end{array}$ & $\begin{array}{l}\text { MW } \\
\text { MW }\end{array}$ & $\begin{array}{l}\text { MW3D } \\
\text { MW11S }\end{array}$ & $\begin{array}{c}133.02-152.73 \\
40-50\end{array}$ & $\begin{array}{l}6160 \\
6157\end{array}$ \\
\hline $\begin{array}{l}3 / 4 / 09 \\
3 / 4 / 09\end{array}$ & $\begin{array}{l}10: 50 \\
11: 44\end{array}$ & $\begin{array}{l}\text { BAMW11SDUP-W-28630 } \\
\text { BAMW11M-W-22716 }\end{array}$ & $\begin{array}{l}\text { MW } \\
\text { MW }\end{array}$ & $\begin{array}{l}\text { MW11S } \\
\text { MW11M }\end{array}$ & $\begin{array}{c}40-50 \\
90-100\end{array}$ & $\begin{array}{l}6157 \\
6157\end{array}$ \\
\hline $3 / 4 / 09$ & $12: 56$ & BAMW11D-W-22717 & MW & MW11D & $125-135$ & 6157 \\
\hline $\begin{array}{l}3 / 4 / 09 \\
3 / 4 / 09\end{array}$ & $\begin{array}{l}13: 05 \\
13: 18\end{array}$ & $\begin{array}{l}\text { BAMW1S-dry-Mar09 } \\
\text { BAMW1D-W-22703 }\end{array}$ & $\begin{array}{l}\text { MW } \\
\text { MW }\end{array}$ & $\begin{array}{l}\text { MW1S } \\
\text { MW1D }\end{array}$ & $\begin{array}{c}13.3-23.3 \\
139.85-159.4\end{array}$ & 6160 \\
\hline $3 / 4 / 09$ & $14: 08$ & BAMW12M-W-22719 & MW & MW12M & $90-100$ & 6157 \\
\hline $3 / 4 / 09$ & $14: 56$ & BAMW17-W-28626 & MW & MW17 & $120-130$ & 6160 \\
\hline
\end{tabular}

3/5/09 Depth to water $=116.1 \mathrm{ft}$. Depth of 2-in. well $=152.73 \mathrm{ft}$. Sample collected by using low-flow bladder pump after purging of $6 \mathrm{~L}$. Pump intake positioned at $142.88 \mathrm{ft}$.

3/5/09 Replicate of sample BAMW3D-W-22705.

$3 / 5 / 09$ Depth to water $=28 \mathrm{ft}$. Depth of $1 \mathrm{in}$. well $=$ $50 \mathrm{ft}$. Sample collected by using low-flow bladder pump after purging of $4.5 \mathrm{~L}$.

Pump intake positioned at $45 \mathrm{ft}$.

3/5/09 Replicate of sample BAMW11S-W-22715.

3/5/09 Depth to water $=80.3 \mathrm{ft}$. Depth of 2 -in. well $=100 \mathrm{ft}$. Sample collected by using lowflow bladder pump after purging of 5.25 L. Pump intake positioned at $95 \mathrm{ft}$.

3/5/09 Depth to water $=105.03 \mathrm{ft}$. Depth of 2 -in well $=135 \mathrm{ft}$. Sample collected by using low-flow bladder pump after purging of $7.5 \mathrm{~L}$. Pump intake positioned at $130 \mathrm{ft}$

- Well was dry.

3/5/09 Depth to water $=119.9 \mathrm{ft}$. Depth of 2 -in. well $=159.4 \mathrm{ft}$. Sample collected by using low-flow bladder pump after purging of $8 \mathrm{~L}$. Pump intake positioned at $149.63 \mathrm{ft}$. Aliquots for verification analysis by TestAmerica collected.

3/5/09 Depth to water $=76.5 \mathrm{ft}$. Depth of 2 -in. well = $99 \mathrm{ft}$. Sample collected by using lowflow bladder pump after purging of 3.75 L. Pump intake positioned at $95 \mathrm{ft}$.

3/5/09 Depth to water $=98.1 \mathrm{ft}$. Depth of 2 -in. well $=130 \mathrm{ft}$. Sample collected by using lowflow bladder pump after purging of $6.5 \mathrm{~L}$. Pump intake positioned at $125 \mathrm{ft}$. 
TABLE A.1 (Cont.)

\begin{tabular}{|c|c|c|c|c|c|c|c|c|}
\hline $\begin{array}{l}\text { Sample } \\
\text { Date }\end{array}$ & Time & Sample & Type $^{b}$ & Location & $\begin{array}{l}\text { Depth }^{\mathrm{C}} \\
\text { (ft BGL) }\end{array}$ & $\begin{array}{l}\text { Chain of } \\
\text { Custody }\end{array}$ & $\begin{array}{l}\text { Shipment } \\
\text { Date }\end{array}$ & Sample Description \\
\hline
\end{tabular}

\section{March 2009 sampling (cont.)}

\begin{tabular}{|c|c|c|c|c|c|c|c|c|}
\hline 3/4/09 & $15: 00$ & BAMW12D-W-22757 & MW & MW12D & $115-125$ & 6157 & $3 / 5 / 09$ & $\begin{array}{l}\text { Depth to water }=96.8 \mathrm{ft} \text {. Depth of } 2 \text {-in. well } \\
=125 \mathrm{ft} \text {. Sample collected by using low- } \\
\text { flow bladder pump after purging of } 5.5 \mathrm{~L} \text {. } \\
\text { Pump intake positioned at } 120 \mathrm{ft} \text {. }\end{array}$ \\
\hline 3/4/09 & $16: 42$ & BAMW2D-W-22704 & MW & MW2D & 133.26-152.93 & 6160 & 3/5/09 & $\begin{array}{l}\text { Depth to water = } 117.1 \mathrm{ft} \text {. Depth of } 2 \text {-in. } \\
\text { well }=152.93 \mathrm{ft} \text {. Sample collected by } \\
\text { using low-flow bladder pump after } \\
\text { purging of } 6.2 \text { L. Pump intake positioned } \\
\text { at } 143.10 \mathrm{ft} \text {. }\end{array}$ \\
\hline 3/4/09 & $16: 50$ & BAQCIR-W-28634 & $\mathrm{RI}$ & QC & - & 6160 & $3 / 5 / 09$ & $\begin{array}{l}\text { Rinsate of decontaminated sampling line } \\
\text { after collection of sample BAMW2D-W- } \\
22704 \text {. }\end{array}$ \\
\hline 3/4/09 & $16: 55$ & BAMW13D-W-22759 & MW & MW13D & $127-137$ & 6157 & 3/5/09 & $\begin{array}{l}\text { Depth to water }=110.58 \mathrm{ft} \text {. Depth of } 2 \text {-in. } \\
\text { well = } 137 \mathrm{ft} \text {. Sample collected by using } \\
\text { low-flow bladder pump after purging of } \\
3.5 \mathrm{~L} \text {. Pump intake positioned at } 132 \mathrm{ft} \text {. }\end{array}$ \\
\hline 3/4/09 & $17: 43$ & BAMW13S-W-22758 & MW & MW13S & $112-122$ & 6157 & $3 / 5 / 09$ & $\begin{array}{l}\text { Depth to water }=88.75 \mathrm{ft} \text {. Depth of } 2 \text {-in. } \\
\text { well }=122 \mathrm{ft} \text {. Sample collected by using } \\
\text { low-flow bladder pump after purging of } \\
5.5 \mathrm{~L} \text {. Pump intake positioned at } 117 \mathrm{ft} \text {. }\end{array}$ \\
\hline 3/4/09 & $17: 50$ & BAMW12S-dry-Mar09 & MW & MW12S & $43-53$ & - & - & Well was dry. \\
\hline 3/4/09 & $18: 14$ & BAMW14S-W-28620 & MW & MW14S & $108-118$ & 6160 & 3/5/09 & $\begin{array}{l}\text { Depth to water = } 101.3 \mathrm{ft} \text {. Depth of } 2 \text {-in. } \\
\text { well = } 118 \mathrm{ft} \text {. Sample collected by using } \\
\text { low-flow bladder pump after purging of } \\
5.2 \mathrm{~L} \text {. Pump intake positioned at } 113 \mathrm{ft} \text {. }\end{array}$ \\
\hline 3/5/09 & $7: 40$ & BAPWS3-W-28629 & PW & PWS3 & 160 & 6160 & $3 / 5 / 09$ & $\begin{array}{l}\text { Sampled from tap in pump house after } \\
\text { purging for } 5 \text { min. }\end{array}$ \\
\hline 3/5/09 & $7: 50$ & BAPWS2-W-28628 & PW & PWS2 & 155 & 6160 & $3 / 5 / 09$ & $\begin{array}{l}\text { Sampled from tap in pump house after } \\
\text { purging for } 5 \text { min. PWS2 had been } \\
\text { operating earlier to fill the city water } \\
\text { tower. }\end{array}$ \\
\hline 3/5/09 & 8:05 & BAOENTRICH-W-28627 & DW & Oentrich & 150 & 6160 & 3/5/09 & $\begin{array}{l}\text { Sampled from hydrant in backyard. Let run } \\
\text { for } 5 \text { min, then sampled. }\end{array}$ \\
\hline
\end{tabular}


TABLE A.1 (Cont.)

\begin{tabular}{|c|c|c|c|c|c|c|c|c|}
\hline $\begin{array}{c}\text { Sample } \\
\text { Date }\end{array}$ & Time & Sample & Type ${ }^{b}$ & Location & $\begin{array}{l}\text { Depthc } \\
\text { (ft BGL) }\end{array}$ & $\begin{array}{l}\text { Chain of } \\
\text { Custody }\end{array}$ & $\begin{array}{l}\text { Shipment } \\
\text { Date }\end{array}$ & Sample Description \\
\hline \multicolumn{9}{|c|}{ March 2009 sampling (cont.) } \\
\hline $3 / 5 / 09$ & $9: 12$ & BAMW14D-W-28621 & MW & MW14D & $123-133$ & 6160 & $3 / 5 / 09$ & $\begin{array}{l}\text { Depth to water = } 103.2 \mathrm{ft} \text {. Depth of } 2 \text {-in. } \\
\text { well = } 133 \mathrm{ft} \text {. Sample collected by using } \\
\text { low-flow bladder pump after purging of } \\
5.3 \mathrm{~L} \text {. Pump intake positioned at } 128 \mathrm{ft} \text {. }\end{array}$ \\
\hline $3 / 5 / 09$ & $9: 49$ & BAMW6D-W-22709 & MW & MW6D & $105-115$ & 6157 & $3 / 5 / 09$ & $\begin{array}{l}\text { Depth to water }=93 \mathrm{ft} \text {. Depth of } 2 \text {-in. well }= \\
115 \mathrm{ft} . \text { Sample collected by using low- } \\
\text { flow bladder pump after purging of } 5 \mathrm{~L} \text {. } \\
\text { Pump intake positioned at } 110 \mathrm{ft} \text {. }\end{array}$ \\
\hline $3 / 5 / 09$ & 10:05 & BAMW6S-W-22708 & MW & MW6S & $90.5-100.5$ & 6157 & $3 / 5 / 09$ & $\begin{array}{l}\text { Depth to water = } 87 \mathrm{ft} \text {. Depth of } 2 \text {-in. well = } \\
100.5 \mathrm{ft} \text {. Sample collected by using low- } \\
\text { flow bladder pump after purging of } 5 \mathrm{~L} \text {. } \\
\text { Pump intake positioned at } 95.5 \mathrm{ft} \text {. }\end{array}$ \\
\hline $3 / 5 / 09$ & $10: 54$ & BAMW7-W-22710 & MW & MW7 & $116-126$ & 6160 & $3 / 5 / 09$ & $\begin{array}{l}\text { Depth to water }=99.8 \mathrm{ft} \text {. Depth of } 2 \text {-in. well } \\
=126 \mathrm{ft} . \text { Sample collected by using low- } \\
\text { flow bladder pump after purging of } 6.9 \mathrm{~L} \text {. } \\
\text { Pump intake positioned at } 121 \mathrm{ft} \text {. }\end{array}$ \\
\hline $3 / 5 / 09$ & $11: 54$ & BAMW10D-W-22714 & MW & MW10D & $115-125$ & 6157 & $3 / 5 / 09$ & $\begin{array}{l}\text { Depth to water = } 101.3 \mathrm{ft} \text {. Depth of } 2 \text {-in. } \\
\text { well = } 125 \mathrm{ft} \text {. Sample collected by using } \\
\text { low-flow bladder pump after purging of } \\
4.5 \mathrm{~L} \text {. Pump intake positioned at } 120 \mathrm{ft} \text {. } \\
\text { Aliquots collected for verification analysis } \\
\text { by TestAmerica. }\end{array}$ \\
\hline $3 / 5 / 09$ & $12: 08$ & BAMW5-W-22707 & MW & MW5 & $110-120$ & 6160 & $3 / 5 / 09$ & $\begin{array}{l}\text { Depth to water }=96.9 \mathrm{ft} \text {. Depth of } 2 \text {-in. well } \\
=120 \mathrm{ft} \text {. Sample collected by using low- } \\
\text { flow bladder pump after purging of } 6 \mathrm{~L} \text {. } \\
\text { Pump intake positioned at } 115 \mathrm{ft} \text {. }\end{array}$ \\
\hline $3 / 5 / 09$ & $12: 47$ & BAMW10S-W-22713 & MW & MW10S & $93-103$ & 6157 & $3 / 5 / 09$ & $\begin{array}{l}\text { Depth to water }=76 \mathrm{ft} \text {. Depth of } 2 \text {-in. well }= \\
103 \mathrm{ft} \text {. Sample collected by using low- } \\
\text { flow bladder pump after purging of } 5.5 \mathrm{~L} \text {. } \\
\text { Pump intake positioned at } 98 \mathrm{ft} \text {. }\end{array}$ \\
\hline $3 / 5 / 09$ & $12: 48$ & BAMW10SDUP-W-28631 & MW & MW10D & $115-125$ & 6157 & $3 / 5 / 09$ & Replicate of sample BAMW10S-W-22713. \\
\hline $3 / 5 / 09$ & 13:26 & BAMW8-W-22711 & MW & MW8 & $110-120$ & 6164 & $3 / 6 / 09$ & $\begin{array}{l}\text { Depth to water }=98.6 \mathrm{ft} \text {. Depth of } 2 \text {-in. well } \\
=120 \mathrm{ft} \text {. Sample collected by using low- } \\
\text { flow bladder pump after purging of } 5.2 \mathrm{~L} \text {. } \\
\text { Pump intake positioned at } 115 \mathrm{ft} \text {. }\end{array}$ \\
\hline
\end{tabular}


TABLE A.1 (Cont.)

\begin{tabular}{|c|c|c|c|c|c|c|c|c|}
\hline $\begin{array}{c}\text { Sample } \\
\text { Date }\end{array}$ & Time & Sample & Type $^{b}$ & Location & $\begin{array}{l}\text { Depth } \\
\text { (ft BGL) }\end{array}$ & $\begin{array}{l}\text { Chain of } \\
\text { Custody }\end{array}$ & $\begin{array}{c}\text { Shipment } \\
\text { Date }\end{array}$ & Sample Description \\
\hline \multicolumn{9}{|c|}{ March 2009 sampling (cont.) } \\
\hline $3 / 5 / 09$ & $14: 34$ & BAMW9-W-22712 & MW & MW9 & $100-110$ & 6164 & $3 / 6 / 09$ & $\begin{array}{l}\text { Depth to water }=90.4 \mathrm{ft} \text {. Depth of } 2 \text {-in. well } \\
=110 \mathrm{ft} \text {. Sample collected by using low- } \\
\text { flow bladder pump after purging of } 4.5 \mathrm{~L} \text {. } \\
\text { Pump intake positioned at } 105 \mathrm{ft} \text {. }\end{array}$ \\
\hline 3/5/09 & $14: 35$ & BAMW9DUP-W-28638 & MW & MW9 & $100-110$ & 6164 & $3 / 6 / 09$ & Replicate of sample BAMW9-W-22712. \\
\hline $3 / 5 / 09$ & $14: 54$ & BAMW4D-W-22706 & MW & MW4D & $98.38-118.22$ & 6164 & $3 / 6 / 09$ & $\begin{array}{l}\text { Depth to water }=94.75 \mathrm{ft} \text {. Depth of } 2 \text {-in. } \\
\text { well }=118.22 \mathrm{ft} \text {. Sample collected by } \\
\text { using low-flow bladder pump after } \\
\text { purging of } 5 \mathrm{~L} \text {. Pump intake positioned at } \\
108.30 \mathrm{ft} \text {. }\end{array}$ \\
\hline $3 / 5 / 09$ & $16: 07$ & BAMW16S-W-28624 & MW & MW16S & $76-86$ & 6164 & $3 / 6 / 09$ & $\begin{array}{l}\text { Depth to water }=69.6 \mathrm{ft} \text {. Depth of } 2 \text {-in. well } \\
=86 \mathrm{ft} \text {. Sample collected by using low- } \\
\text { flow bladder pump after purging of } 5 \mathrm{~L} \text {. } \\
\text { Pump intake positioned at } 81 \mathrm{ft} \text {. }\end{array}$ \\
\hline $3 / 5 / 09$ & 16:36 & BAMW15D-W-28623 & MW & MW15D & $105-115$ & 6164 & $3 / 6 / 09$ & $\begin{array}{l}\text { Depth to water }=73.6 \mathrm{ft} \text {. Depth of } 2 \text {-in. well } \\
=115 \mathrm{ft} \text {. Sample collected by using low- } \\
\text { flow bladder pump after purging of } 5 \mathrm{~L} \text {. } \\
\text { Pump intake positioned at } 110 \mathrm{ft} .\end{array}$ \\
\hline $3 / 5 / 09$ & $16: 50$ & BAMW15S-W-28622 & MW & MW15S & $88-98$ & 6164 & $3 / 6 / 09$ & $\begin{array}{l}\text { Depth to water }=78.8 \mathrm{ft} \text {. Depth of } 2 \text {-in. well } \\
=98 \mathrm{ft} \text {. Sample collected by using low- } \\
\text { flow bladder pump after purging of } 7 \mathrm{~L} \text {. } \\
\text { Pump intake positioned at } 93 \mathrm{ft} \text {. }\end{array}$ \\
\hline $3 / 5 / 09$ & $16: 53$ & BAMW16D-W-28625 & MW & MW16D & $90-100$ & 6164 & $3 / 6 / 09$ & $\begin{array}{l}\text { Depth to water }=69 \mathrm{ft} \text {. Depth of } 2 \text {-in. well }= \\
100 \mathrm{ft} \text {. Sample collected by using low- } \\
\text { flow bladder pump after purging of } 4 \mathrm{~L} \text {. } \\
\text { Pump intake positioned at } 95 \mathrm{ft} \text {. }\end{array}$ \\
\hline $3 / 5 / 09$ & $17: 00$ & BAQCTB-W-28637 & TB & QC & - & 6157 & $3 / 5 / 09$ & $\begin{array}{l}\text { Trip blank sent to the AGEM Laboratory for } \\
\text { organic analysis with water samples } \\
\text { listed on chain-of-custody forms (COCs) } \\
6157 \text { and } 6160 \text {, as well as to } \\
\text { TestAmerica with verification samples } \\
\text { listed on COC } 4393 \text {. }\end{array}$ \\
\hline $3 / 6 / 09$ & $17: 55$ & BAQCTB-W-28635 & TB & QC & - & 6164 & $3 / 6 / 09$ & $\begin{array}{l}\text { Trip blank sent to the AGEM Laboratory for } \\
\text { organic analysis with water samples } \\
\text { listed on COC } 6164 \text {. }\end{array}$ \\
\hline
\end{tabular}


TABLE A.1 (Cont.)

\begin{tabular}{|c|c|c|c|c|c|c|c|c|}
\hline $\begin{array}{c}\text { Sample } \\
\text { Date }\end{array}$ & Time & Sample & Type ${ }^{b}$ & Location & $\begin{array}{l}\text { Depthc } \\
\text { (ft BGL) }\end{array}$ & $\begin{array}{l}\text { Chain of } \\
\text { Custody }\end{array}$ & $\begin{array}{c}\text { Shipment } \\
\text { Date }\end{array}$ & Sample Description \\
\hline
\end{tabular}

\section{June 2009 sampling}

$6 / 17 / 09$

16:34 BAMW1D-W-28639

MW

MW1D

$139.85-159.4$

2526

$6 / 17 / 09$

16:40 BAMW1S-dry-Jun09

$6 / 17 / 09$

17:18 BAMW15D-W-28662

$\begin{array}{lcc}\text { MW } & \text { MW1S } & 13.3-23.3 \\ \text { MW } & \text { MW15D } & 105-115\end{array}$

$6 / 17 / 09$

18:16 BAMW15S-W-28661

MW

MW15S

88-98

2526

6/17/09

18:26 BAMW17-W-28665

MW

MW17

$120-130$

2526

$6 / 17 / 09$

$6 / 17 / 09$

18:28 BAMW17DUP-W-28669

MW

MW
MW17

MW9
120-130

100-110
526

6/18/09 Depth to water $=110.15 \mathrm{ft}$. Depth of 2 -in. well $=152.73 \mathrm{ft}$. Sample collected by using a low-flow bladder pump after purging of of $7.8 \mathrm{~L}$. Pump intake positioned at $142.88 \mathrm{ft}$

6/18/09 Depth to water $=115.6 \mathrm{ft}$. Depth of 2-in. well = $159.4 \mathrm{ft}$. Sample collected by using a low-flow bladder pump after purging of

of $4 \mathrm{~L}$. Pump intake positioned at $149.63 \mathrm{ft}$. Aliquots collected for verification analysis by TestAmerica.

2526 - Well was dry.

6/18/09 Depth to water $=67.74 \mathrm{ft}$. Depth of 2-in. well = $115 \mathrm{ft}$. Sample collected by using a low-flow bladder pump after purging of of $10 \mathrm{~L}$. Pump intake positioned at $110 \mathrm{ft}$ Aliquots collected for verification analysis by TestAmerica.

6/18/09 Depth to water $=75.92 \mathrm{ft}$. Depth of 2-in. well $=98 \mathrm{ft}$. Sample collected by using a low-flow bladder pump after purging of of $7 \mathrm{~L}$. Pump intake positioned at $93 \mathrm{ft}$.

6/18/09 Depth to water $=95.75 \mathrm{ft}$. Depth of 2-in well = $130 \mathrm{ft}$. Sample collected by using a low-flow bladder pump after purging of of $10.5 \mathrm{~L}$. Pump intake positioned at $125 \mathrm{ft}$

6/18/09 Replicate of sample BAMW17-W-28665.

6/18/09 Depth to water $=83.16 \mathrm{ft}$. Depth of 2-in. well $=110 \mathrm{ft}$. Sample collected by using a low-flow bladder pump after purging of of $7 \mathrm{~L}$. Pump intake positioned at $105 \mathrm{ft}$. 
TABLE A.1 (Cont.)

\begin{tabular}{|c|c|c|c|c|c|c|c|c|}
\hline $\begin{array}{l}\text { Sample } \\
\text { Date }\end{array}$ & Time & Sample & Type $^{b}$ & Location & $\begin{array}{c}\text { Depth } \\
\text { (ft BGL) }\end{array}$ & $\begin{array}{l}\text { Chain of } \\
\text { Custody }\end{array}$ & $\begin{array}{l}\text { Shipment } \\
\text { Date }\end{array}$ & Sample Description \\
\hline
\end{tabular}

June 2009 sampling (cont.)

$6 / 18 / 0$

9:45 BAPWS2-W -28667

$6 / 18 / 09$

9:58 BAPWS3-W-28668

6/18/09

$10: 58$

BAMW14S-W-28659

6/18/09 11:02 BAOENTRICH-W-28666

$6 / 18 / 09$

11:04 BAQCIR-W-28672

$6 / 18 / 09$

12:30 BAQCTB-W-28674

$6 / 18 / 09$

13:12 BAMW6S-W-28644

MW

MW6S

$90.5-100.5$

MW $\quad$ MW14D $123-133$

6/18/09 Depth to water $=115.70 \mathrm{ft}$. Depth of 2-in well $=152.93 \mathrm{ft}$. Sample collected by using a low-flow bladder pump after purging of of $7.5 \mathrm{~L}$. Pump intake positioned at $143.10 \mathrm{ft}$. Aliquots collected for verification analysis by TestAmerica.

6/18/09 Well had been pumping since 6 a.m. on June 18. Let run from tap for $5 \mathrm{~min}$, then sampled.

6/18/09 Well was used on June 17. Let pump run for $10 \mathrm{~min}$, then sampled.

6/18/09 Depth to water $=99.8 \mathrm{ft}$. Depth of 2 -in. well $=118 \mathrm{ft}$. Sample collected by using a low-flow bladder pump after purging of of 11.4 L. Pump intake positioned at $113 \mathrm{ft}$

6/18/09 Pumped $10 \mathrm{gal}$, then sampled.

6/18/09 Rinsate of decontaminated sampling line after collection of sample BAMW14S-W28659

6/18/09 Trip blank sent to the AGEM Laboratory for organic analyses with water samples listed on COC 2527.

6/18/09 Depth to water $=86.05 \mathrm{ft}$. Depth of 2 -in well $=100.5 \mathrm{ft}$. Sample collected by using a low-flow bladder pump after purging of $12 \mathrm{~L}$. Pump intake positioned at $95.50 \mathrm{ft}$. Aliquots collected for verification analysis by TestAmerica.

6/20/09 Depth to water $=97.75 \mathrm{ft}$. Depth of 2-in. well $=118 \mathrm{ft}$. Sample collected by using a low-flow bladder pump after purging of $6 \mathrm{~L}$. Pump intake positioned at $113 \mathrm{ft}$. 
TABLE A.1 (Cont.)

\begin{tabular}{|c|c|c|c|c|c|c|c|c|}
\hline $\begin{array}{l}\text { Sample } \\
\text { Date }\end{array}$ & Time & Sample & Type ${ }^{b}$ & Location & $\begin{array}{l}\text { Depth } \\
\text { (ft BGL) }\end{array}$ & $\begin{array}{l}\text { Chain of } \\
\text { Custody }\end{array}$ & $\begin{array}{l}\text { Shipment } \\
\text { Date }\end{array}$ & Sample Description \\
\hline \multicolumn{9}{|c|}{ June 2009 sampling (cont.) } \\
\hline 6/18/09 & $16: 54$ & BAMW6D-W-28645 & MW & MW6D & $105-115$ & 3075 & $6 / 20 / 09$ & $\begin{array}{l}\text { Depth to water }=88.7 \mathrm{ft} \text {. Depth of } 2 \text {-in. well } \\
=115 \mathrm{ft} \text {. Sample collected by using a } \\
\text { low-flow bladder pump after purging of } \\
5 \mathrm{~L} \text {. Pump intake positioned at } 110 \mathrm{ft} \text {. }\end{array}$ \\
\hline $6 / 18 / 09$ & $16: 56$ & BAMW6DDUP-W-28670 & MW & MW6D & $105-115$ & 3075 & $6 / 20 / 09$ & Replicate of sample BAMW6D-W-28645. \\
\hline $6 / 18 / 09$ & 17:06 & BAMW16D-W-28664 & MW & MW16D & $90-100$ & 3074 & $6 / 20 / 09$ & $\begin{array}{l}\text { Depth to water }=66.49 \mathrm{ft} \text {. Depth of } 2 \text {-in. } \\
\text { well }=100 \mathrm{ft} \text {. Sample collected by using a } \\
\text { low-flow bladder pump after purging of } \\
6 \mathrm{~L} \text {. Pump intake positioned at } 95 \mathrm{ft} \text {. }\end{array}$ \\
\hline $6 / 18 / 09$ & $17: 07$ & BAMW16DDUP-W-28671 & MW & MW16D & $90-100$ & 3074 & $6 / 20 / 09$ & Replicate of sample BAMW16D-W-28664. \\
\hline $6 / 18 / 09$ & $17: 58$ & BAMW16S-W-28663 & MW & MW16S & $76-86$ & 3074 & $6 / 20 / 09$ & $\begin{array}{l}\text { Depth to water }=66.93 \mathrm{ft} \text {. Depth of } 2 \text {-in. } \\
\text { well }=86 \mathrm{ft} \text {. Sample collected by using a } \\
\text { low-flow bladder pump after purging of } \\
6 \mathrm{~L} \text {. Pump intake positioned at } 81 \mathrm{ft} \text {. }\end{array}$ \\
\hline $6 / 18 / 09$ & 18:00 & BAMW13S-W-28657 & MW & MW13S & $112-122$ & 3075 & $6 / 20 / 09$ & $\begin{array}{l}\text { Depth to water }=86.85 \mathrm{ft} \text {. Depth of } 2 \text {-in. } \\
\text { well }=122 \mathrm{ft} \text {. Sample collected by using a } \\
\text { low-flow bladder pump after purging of } \\
9 \mathrm{~L} \text {. Pump intake positioned at } 117 \mathrm{ft} \text {. }\end{array}$ \\
\hline $6 / 18 / 09$ & 19:02 & BAMW13D-W-28658 & MW & MW13D & $127-137$ & 3074 & $6 / 20 / 09$ & $\begin{array}{l}\text { Depth to water = } 106.8 \mathrm{ft} \text {. Depth of } 2 \text {-in. } \\
\text { well = } 137 \mathrm{ft} \text {. Sample collected by using a } \\
\text { low-flow bladder pump after purging of } \\
4.8 \mathrm{~L} \text {. Pump intake positioned at } 132 \mathrm{ft} \text {. }\end{array}$ \\
\hline $6 / 18 / 09$ & $19: 42$ & BAMW4D-W-28642 & MW & MW4D & $98.38-118.22$ & 3074 & $6 / 20 / 09$ & $\begin{array}{l}\text { Depth to water }=92.25 \mathrm{ft} \text {. Depth of } 2 \text {-in. } \\
\text { well }=118.22 \mathrm{ft} . \text { Sample collected by } \\
\text { using a low-flow bladder pump after } \\
\text { purging of } 7 \mathrm{~L} \text {. Pump intake positioned at } \\
108.30 \mathrm{ft} .\end{array}$ \\
\hline $6 / 19 / 09$ & $9: 26$ & BAMW5-W-28643 & MW & MW5 & $110-120$ & 3074 & $6 / 20 / 09$ & $\begin{array}{l}\text { Depth to water }=93.8 \mathrm{ft} \text {. Depth of } 2 \text {-in. well } \\
=120 \mathrm{ft} \text {. Sample collected by using a } \\
\text { low-flow bladder pump after purging of } \\
8 \mathrm{~L} \text {. Pump intake positioned at } 115 \mathrm{ft} \text {. }\end{array}$ \\
\hline $6 / 19 / 09$ & $10: 34$ & BAMW7-W-28646 & MW & MW7 & $116-126$ & 3074 & $6 / 20 / 09$ & $\begin{array}{l}\text { Depth to water }=95.75 \mathrm{ft} \text {. Depth of } 2 \text {-in. } \\
\text { well = } 126 \mathrm{ft} \text {. Sample collected by using a } \\
\text { low-flow bladder pump after purging of } \\
5 \mathrm{~L} \text {. Pump intake positioned at } 121 \mathrm{ft} \text {. }\end{array}$ \\
\hline
\end{tabular}


TABLE A.1 (Cont.)

\begin{tabular}{|c|c|c|c|c|c|c|c|c|}
\hline $\begin{array}{l}\text { Sample } \\
\text { Date }\end{array}$ & Time & Sample & Type & Location & $\begin{array}{l}\text { Depthc } \\
\text { (ft BGL) }\end{array}$ & $\begin{array}{l}\text { Chain of } \\
\text { Custody }\end{array}$ & $\begin{array}{l}\text { Shipment } \\
\text { Date }\end{array}$ & Sample Description \\
\hline \multicolumn{9}{|c|}{ June 2009 sampling (cont.) } \\
\hline $6 / 19 / 09$ & $11: 40$ & BAMW12M-W-28655 & MW & MW12M & $90-100$ & 3074 & $6 / 20 / 09$ & $\begin{array}{l}\text { Depth to water }=70.05 \mathrm{ft} \text {. Depth of } 2 \text {-in. } \\
\text { well }=100 \mathrm{ft} . \text { Sample collected by using a } \\
\text { low-flow bladder pump after purging of } \\
6.5 \mathrm{~L} \text {. Pump intake positioned at } 95 \mathrm{ft} \text {. }\end{array}$ \\
\hline $6 / 19 / 09$ & $12: 28$ & BAMW12D-W-28656 & MW & MW12D & $115-125$ & 3074 & $6 / 20 / 09$ & $\begin{array}{l}\text { Depth to water }=93.65 \mathrm{ft} \text {. Depth of } 2 \text {-in. } \\
\text { well }=125 \mathrm{ft} \text {. Sample collected by using a } \\
\text { low-flow bladder pump after purging of } \\
7 \mathrm{~L} \text {. Pump intake positioned at } 120 \mathrm{ft} \text {. }\end{array}$ \\
\hline $6 / 19 / 09$ & $12: 36$ & BAMW10S-W-28649 & MW & MW10S & $93-103$ & 3075 & $6 / 20 / 09$ & $\begin{array}{l}\text { Depth to water }=73.4 \mathrm{ft} \text {. Depth of } 2 \text {-in. well } \\
=103 \mathrm{ft} \text {. Sample collected by using a } \\
\text { low-flow bladder pump after purging of } \\
9.5 \mathrm{~L} \text {. Pump intake positioned at } 98 \mathrm{ft} \text {. }\end{array}$ \\
\hline $6 / 19 / 09$ & $12: 55$ & BAQCIR-W-28673 & $\mathrm{RI}$ & QC & - & 3074 & $6 / 20 / 09$ & $\begin{array}{l}\text { Rinsate of decontaminated sampling line } \\
\text { after collection of sample BAMW12D-W- } \\
28656 \text {. }\end{array}$ \\
\hline $6 / 19 / 09$ & $13: 38$ & BAMW10D-W-28650 & MW & MW10D & $115-125$ & 3075 & $6 / 20 / 09$ & $\begin{array}{l}\text { Depth to water }=96.75 \mathrm{ft} \text {. Depth of } 2 \text {-in. } \\
\text { well }=125 \mathrm{ft} \text {. Sample collected by using a } \\
\text { low-flow bladder pump after purging of } \\
4.5 \text { L. Pump intake positioned at } 120 \mathrm{ft} \text {. }\end{array}$ \\
\hline $6 / 19 / 09$ & $14: 34$ & BAMW8-W-28647 & MW & MW8 & $110-120$ & 3075 & $6 / 20 / 09$ & $\begin{array}{l}\text { Depth to water }=95.0 \mathrm{ft} \text {. Depth of } 2 \text {-in. well } \\
=120 \mathrm{ft} \text {. Sample collected by using a } \\
\text { low-flow bladder pump after purging of } \\
6 \mathrm{~L} \text {. Pump intake positioned at } 115 \mathrm{ft} \text {. }\end{array}$ \\
\hline $6 / 19 / 09$ & $14: 55$ & BAMW12S-W-28654 & MW & MW12S & $43-53$ & 3075 & $6 / 20 / 09$ & $\begin{array}{l}\text { Water present at bottom of well, }<1 \mathrm{ft} \text {. } \\
\text { Collected sample and partial field } \\
\text { measurements after purging of } 0.4 \mathrm{~L} \text {. }\end{array}$ \\
\hline $6 / 19 / 09$ & $16: 22$ & BAMW11D-W-28653 & MW & MW11D & $125-135$ & 3075 & $6 / 20 / 09$ & $\begin{array}{l}\text { Depth to water }=100.9 \mathrm{ft} \text {. Depth of } 2 \text {-in. } \\
\text { well }=135 \mathrm{ft} \text {. Sample collected by using a } \\
\text { low-flow bladder pump after purging of } \\
9 \mathrm{~L} \text {. Pump intake positioned at } 130 \mathrm{ft} \text {. }\end{array}$ \\
\hline $6 / 19 / 09$ & $17: 26$ & BAMW11M-W-28652 & MW & MW11M & $90-100$ & 3075 & $6 / 20 / 09$ & $\begin{array}{l}\text { Depth to water }=78.90 \mathrm{ft} \text {. Depth of } 2 \text {-in. } \\
\text { well }=100 \mathrm{ft} \text {. Sample collected by using a } \\
\text { low-flow bladder pump after purging of } \\
13 \mathrm{~L} \text {. Pump intake positioned at } 95 \mathrm{ft} \text {. }\end{array}$ \\
\hline
\end{tabular}


TABLE A.1 (Cont.)

\begin{tabular}{|c|c|c|c|c|c|c|c|c|}
\hline $\begin{array}{l}\text { Sample } \\
\text { Date }\end{array}$ & Time & Sample & Type & Location & $\begin{array}{l}\text { Depthc } \\
\text { (ft BGL) }\end{array}$ & $\begin{array}{l}\text { Chain of } \\
\text { Custody }\end{array}$ & $\begin{array}{l}\text { Shipment } \\
\text { Date }\end{array}$ & Sample Description \\
\hline \multicolumn{9}{|c|}{ June 2009 sampling (cont.) } \\
\hline 6/19/09 & $18: 40$ & BAMW11S-W-28651 & MW & MW11S & $40-50$ & 3075 & $6 / 20 / 09$ & $\begin{array}{l}\text { Depth to water }=26.64 \mathrm{ft} \text {. Depth of } 1 \text {-in. } \\
\text { well }=50 \mathrm{ft} \text {. Sample collected by using a } \\
\text { low-flow bladder pump after purging of } \\
6.5 \mathrm{~L} \text {. Pump intake positioned at } 45 \mathrm{ft} \text {. }\end{array}$ \\
\hline 6/19/09 & 19:00 & BAQCTB-W-28675 & TB & QC & - & 3074 & $6 / 20 / 09$ & $\begin{array}{l}\text { Trip blank sent to the AGEM Laboratory for } \\
\text { organic analyses with water samples } \\
\text { listed on COC } 3074 \text {. }\end{array}$ \\
\hline $6 / 19 / 09$ & 19:01 & BAQCTB-W-28676 & TB & QC & - & 3075 & $6 / 20 / 09$ & $\begin{array}{l}\text { Trip blank sent to the AGEM Laboratory for } \\
\text { organic analyses with water samples } \\
\text { listed on COC } 3075 \text {. }\end{array}$ \\
\hline
\end{tabular}

a All samples collected were water.

b Sample types: DW, domestic well; MW, monitoring well; PW, public water supply well; RI, rinsate; TB, trip blank.

c Depth is in feet below the top of the well casing. 
TABLE A.2 Field measurements for groundwater samples collected at Barnes, July 2006 to June 2009.

\begin{tabular}{|c|c|c|c|c|c|c|c|}
\hline Well & $\begin{array}{l}\text { Screen Interval } \\
\quad(\mathrm{ft} B G L)\end{array}$ & $\begin{array}{l}\text { Sample } \\
\text { Date }\end{array}$ & $\begin{array}{l}\text { Temperature } \\
\left({ }^{\circ} \mathrm{C}\right)\end{array}$ & $\mathrm{pH}$ & $\begin{array}{l}\text { Conductivity } \\
(\mu \mathrm{S} / \mathrm{cm})\end{array}$ & $\begin{array}{c}\text { Dissolved } \\
\text { Oxygen } \\
\text { (mg/L) }\end{array}$ & $\begin{array}{c}\text { Oxidation- } \\
\text { Reduction } \\
\text { Potential } \\
\quad(\mathrm{mV})\end{array}$ \\
\hline \multicolumn{8}{|c|}{ Previously existing KDHE monitoring wells } \\
\hline \multirow[t]{8}{*}{ MW1S } & 13.3-23.3 & $7 / 19 / 06^{a}$ & - & - & - & - & - \\
\hline & & $4 / 4 / 07^{a}$ & - & - & - & - & - \\
\hline & & $11 / 18 / 07^{a}$ & - & - & - & - & - \\
\hline & & $3 / 4 / 08^{a}$ & - & - & - & - & - \\
\hline & & $7 / 9 / 08^{a}$ & - & - & - & - & - \\
\hline & & $10 / 22 / 08^{a}$ & - & - & - & - & - \\
\hline & & $3 / 4 / 09^{a}$ & - & - & - & - & - \\
\hline & & $6 / 17 / 09^{a}$ & - & - & - & - & - \\
\hline \multirow[t]{8}{*}{ MW1D } & $139.85-159.4$ & $7 / 19 / 06$ & 22.8 & 7.15 & 945 & - & - \\
\hline & & $4 / 4 / 07$ & 15.7 & 6.30 & 855 & - & - \\
\hline & & $11 / 18 / 07$ & 12.7 & 7.62 & 712 & - & - \\
\hline & & $3 / 4 / 08$ & 5.5 & 7.22 & 1167 & 11.6 & 244 \\
\hline & & 7/9/08 & 18.1 & 7.05 & 992 & 16.2 & 98 \\
\hline & & $10 / 22 / 08$ & 12.6 & 7.07 & 937 & 8.95 & 108 \\
\hline & & $3 / 4 / 09$ & 13.8 & 7.07 & 962 & 8.94 & 253 \\
\hline & & $6 / 17 / 09$ & 23.3 & 7.07 & 1021 & 5.43 & 106 \\
\hline \multirow[t]{8}{*}{ MW2D } & $133.26-152.93$ & 7/19/06 & 24.7 & 7.72 & 946 & - & - \\
\hline & & $4 / 4 / 07$ & 15.1 & 6.32 & 887 & - & - \\
\hline & & $11 / 18 / 07$ & 12.1 & 6.96 & 1448 & - & - \\
\hline & & $3 / 7 / 08$ & 6.5 & 7.22 & 1198 & 4.61 & 197 \\
\hline & & $7 / 10 / 08$ & 18.4 & 6.91 & 1163 & 5.03 & 155 \\
\hline & & 10/22/08 & 11.6 & 7.07 & 931 & 6.19 & 132 \\
\hline & & $3 / 4 / 09$ & 14.5 & 7.06 & 1126 & 5.60 & 243 \\
\hline & & 6/18/09 & 18.7 & 6.97 & 1235 & 3.55 & 116 \\
\hline \multirow[t]{8}{*}{ MW3D } & $133.02-152.73$ & 7/19/06 & 23.0 & 7.06 & 976 & - & - \\
\hline & & $4 / 4 / 07$ & 15.6 & 6.37 & 989 & - & - \\
\hline & & $11 / 19 / 07$ & 10.5 & 7.16 & 1093 & - & - \\
\hline & & $3 / 7 / 08$ & 8.2 & 7.09 & 1195 & 5.34 & 255 \\
\hline & & 7/10/08 & 19.8 & 6.99 & 1177 & 13.8 & 110 \\
\hline & & $10 / 22 / 08$ & 13.5 & 7.01 & 1238 & 4.46 & 84 \\
\hline & & $3 / 4 / 09$ & 12.8 & 7.08 & 1062 & 7.00 & 210 \\
\hline & & $6 / 17 / 09$ & 18.5 & 6.65 & 1038 & 5.90 & 110 \\
\hline \multirow[t]{8}{*}{ MW4D } & $98.38-118.22$ & 7/20/06 & 23.5 & 6.26 & 968 & - & - \\
\hline & & $4 / 6 / 07$ & 11.3 & 6.21 & 1018 & - & - \\
\hline & & $11 / 19 / 07$ & 15.7 & 6.98 & 1022 & - & - \\
\hline & & $3 / 9 / 08$ & 11.5 & 7.14 & 859 & 6.57 & 201 \\
\hline & & $7 / 12 / 08$ & 14.4 & 6.94 & 1001 & 6.77 & 149 \\
\hline & & $10 / 23 / 08$ & 13.0 & 7.02 & 973 & 5.56 & 94 \\
\hline & & $3 / 5 / 09$ & 15.9 & 7.61 & 1402 & 4.04 & 17 \\
\hline & & 6/18/09 & 18.5 & 7.03 & 975 & 5.72 & 127 \\
\hline
\end{tabular}


TABLE A.2 (Cont.)

\begin{tabular}{|c|c|c|c|c|c|c|c|}
\hline Well & $\begin{array}{l}\text { Screen Interval } \\
\quad(\mathrm{ft} B G L)\end{array}$ & $\begin{array}{l}\text { Sample } \\
\text { Date }\end{array}$ & $\begin{array}{c}\text { Temperature } \\
\left({ }^{\circ} \mathrm{C}\right)\end{array}$ & $\mathrm{pH}$ & $\begin{array}{l}\text { Conductivity } \\
(\mu \mathrm{S} / \mathrm{cm})\end{array}$ & $\begin{array}{c}\text { Dissolved } \\
\text { Oxygen } \\
(\mathrm{mg} / \mathrm{L})\end{array}$ & $\begin{array}{r}\text { Reduct } \\
\text { Potent } \\
(\mathrm{mV})\end{array}$ \\
\hline \multicolumn{8}{|c|}{ CCC/USDA wells installed during 2006-2007 investigation } \\
\hline \multirow[t]{7}{*}{ MW5 } & $110-120$ & $4 / 6 / 07$ & 13.9 & 6.17 & 1705 & - & - \\
\hline & & $11 / 19 / 07$ & 15.2 & 6.74 & 3070 & - & - \\
\hline & & $3 / 8 / 08$ & 9.9 & 6.76 & 2770 & 0.66 & 123 \\
\hline & & $7 / 11 / 08$ & 18.8 & 6.66 & 2930 & 1.32 & 37 \\
\hline & & 10/23/08 & 12.8 & 6.78 & 2384 & 0.67 & 20 \\
\hline & & $3 / 5 / 09$ & 15.9 & 6.86 & 2146 & 2.36 & 56 \\
\hline & & 6/19/09 & 16.4 & 6.71 & 2292 & 1.01 & 45 \\
\hline \multirow[t]{7}{*}{ MW6S } & $90.5-100.5$ & $4 / 4 / 07^{a}$ & - & - & - & - & - \\
\hline & & $11 / 19 / 07$ & 12.0 & 7.60 & 723 & - & - \\
\hline & & $3 / 8 / 08$ & 4.7 & 7.77 & 673 & 6.72 & 272 \\
\hline & & 7/11/08 & 28.2 & 7.61 & 753 & 9.85 & 92 \\
\hline & & 10/23/08 & 11.9 & 11.17 & 582 & 5.12 & 91 \\
\hline & & 3/5/09 & 13.9 & 7.88 & 603 & 5.23 & 18 \\
\hline & & $6 / 18 / 09$ & 19.5 & 7.70 & 698 & 4.52 & 27 \\
\hline \multirow[t]{7}{*}{ MW6D } & $105-115$ & $4 / 5 / 07$ & 6.2 & 6.11 & 936 & - & - \\
\hline & & $11 / 19 / 07$ & 13.6 & 7.00 & 1103 & - & - \\
\hline & & 3/8/08 & 9.1 & 7.15 & 908 & 5.56 & 241 \\
\hline & & $7 / 11 / 08$ & 19.8 & 7.05 & 999 & 12.8 & 100 \\
\hline & & 10/23/08 & 12.0 & 7.18 & 957 & 6.27 & 128 \\
\hline & & 3/5/09 & 13.4 & 7.22 & 903 & 3.07 & 21 \\
\hline & & 6/18/09 & 19.0 & 6.86 & 992 & 4.44 & 114 \\
\hline \multirow[t]{7}{*}{ MW7 } & $116-126$ & $4 / 6 / 07$ & 14.1 & 6.30 & 1051 & - & - \\
\hline & & $11 / 19 / 07$ & 14.6 & 7.16 & 890 & - & - \\
\hline & & 3/9/08 & 13.1 & 7.10 & 1068 & 4.24 & 186 \\
\hline & & 7/12/08 & 14.4 & 6.95 & 1238 & 4.36 & 98 \\
\hline & & $10 / 23 / 08$ & 12.7 & 7.16 & 1191 & 8.61 & 122 \\
\hline & & 3/5/09 & 15.3 & 7.11 & 1141 & 9.93 & 126 \\
\hline & & 6/19/09 & 16.3 & 7.05 & 1174 & 4.32 & 48 \\
\hline \multirow[t]{7}{*}{ MW8 } & $110-120$ & $4 / 6 / 07$ & 12.1 & 6.23 & 974 & - & - \\
\hline & & $11 / 19 / 07$ & 14.6 & 7.03 & 909 & - & - \\
\hline & & 3/10/08 & 13.1 & 7.09 & 961 & 6.71 & 182 \\
\hline & & 7/11/08 & 18.6 & 6.38 & 1049 & 6.19 & 152 \\
\hline & & 10/23/08 & 12.9 & 7.06 & 948 & 8.74 & 97 \\
\hline & & 3/5/09 & 16.2 & 7.12 & 985 & 9.43 & 165 \\
\hline & & $6 / 19 / 09$ & 18.0 & 7.07 & 972 & 6.65 & 102 \\
\hline \multirow[t]{7}{*}{ MW9 } & $100-110$ & $4 / 5 / 07$ & 12.9 & 6.20 & 976 & - & - \\
\hline & & 11/19/07 & 16.5 & 7.21 & 1066 & - & - \\
\hline & & $3 / 9 / 08$ & 11.2 & 7.07 & 928 & 5.80 & 239 \\
\hline & & $7 / 11 / 08$ & 17.7 & 6.58 & 1010 & 5.63 & 189 \\
\hline & & $10 / 24 / 08$ & 13.0 & 7.06 & 888 & 5.42 & 79 \\
\hline & & 3/5/09 & 16.2 & 7.10 & 939 & 8.40 & 173 \\
\hline & & 6/17/09 & 15.9 & 6.87 & 907 & 5.62 & 146 \\
\hline
\end{tabular}


TABLE A.2 (Cont.)

\begin{tabular}{|c|c|c|c|c|c|c|c|}
\hline Well & $\begin{array}{l}\text { Screen Interval } \\
\quad(\mathrm{ft} B G L)\end{array}$ & $\begin{array}{l}\text { Sample } \\
\text { Date }\end{array}$ & $\begin{array}{l}\text { Temperature } \\
\left({ }^{\circ} \mathrm{C}\right)\end{array}$ & $\mathrm{pH}$ & $\begin{array}{l}\text { Conductivity } \\
(\mu \mathrm{S} / \mathrm{cm})\end{array}$ & $\begin{array}{c}\text { Dissolved } \\
\text { Oxygen } \\
\text { (mg/L) }\end{array}$ & $\begin{array}{c}\text { Oxidation- } \\
\text { Reduction } \\
\text { Potential } \\
\quad(\mathrm{mV})\end{array}$ \\
\hline \multicolumn{8}{|c|}{ CCC/USDA wells installed during 2006-2007 investigation (cont.) } \\
\hline \multirow[t]{7}{*}{ MW10S } & $93-103$ & $\begin{array}{r}4 / 6 / 07 \\
\end{array}$ & 13.2 & 6.36 & 1004 & - & - \\
\hline & & 11/19/07 & 14.5 & 7.22 & 942 & - & - \\
\hline & & 3/10/08 & 12.7 & 7.08 & 912 & 5.18 & 176 \\
\hline & & $7 / 11 / 08$ & 17.3 & 6.91 & 975 & 12.8 & 119 \\
\hline & & $10 / 23 / 08$ & 13.4 & 7.08 & 913 & 5.39 & 78 \\
\hline & & 3/5/09 & 15.3 & 7.25 & 895 & 2.66 & 13 \\
\hline & & $6 / 19 / 09$ & 16.0 & 7.12 & 925 & 5.44 & 104 \\
\hline \multirow{7}{*}{ MW10D } & $115-125$ & $4 / 6 / 07$ & 12.1 & 6.21 & 992 & - & - \\
\hline & & $11 / 19 / 07$ & 14.5 & 7.42 & 1175 & - & - \\
\hline & & $3 / 9 / 08$ & 13.7 & 7.01 & 1024 & 5.07 & 236 \\
\hline & & 7/11/08 & 17.4 & 6.78 & 1090 & 12.6 & 117 \\
\hline & & 10/23/08 & 13.5 & 7.01 & 1000 & 5.00 & 93 \\
\hline & & 3/5/09 & 15.9 & 7.20 & 969 & 4.37 & 12 \\
\hline & & $6 / 19 / 09$ & 16.9 & 7.08 & 1035 & 5.70 & 109 \\
\hline \multirow[t]{7}{*}{ MW11S } & $40-50$ & $4 / 4 / 07$ & 12.8 & 6.14 & 1027 & - & - \\
\hline & & 11/19/07 & 11.2 & 7.15 & 1174 & - & - \\
\hline & & $3 / 5 / 08$ & 9.4 & 6.81 & 1122 & 2.26 & 241 \\
\hline & & 7/10/08 & 19.5 & 6.47 & 1224 & 1.86 & 166 \\
\hline & & 10/23/08 & 10.2 & 6.99 & 1085 & 5.80 & 146 \\
\hline & & 3/4/09 & 14.5 & 7.11 & 1186 & 4.32 & 37 \\
\hline & & 6/19/09 & 15.0 & 6.81 & 1159 & 3.11 & 173 \\
\hline \multirow{7}{*}{ MW11M } & $90-100$ & $4 / 5 / 07$ & 7.5 & 7.60 & 1097 & - & - \\
\hline & & 11/19/07 & 11.9 & 7.17 & 1144 & - & - \\
\hline & & 3/6/08 & 10.8 & 7.06 & 997 & 2.65 & 254 \\
\hline & & 7/10/08 & 31.9 & 7.08 & 1124 & 3.88 & 149 \\
\hline & & $10 / 23 / 08$ & 12.4 & 7.06 & 962 & 3.19 & 116 \\
\hline & & 3/4/09 & 13.6 & 7.33 & 910 & 4.90 & 28 \\
\hline & & $6 / 19 / 09$ & 14.7 & 6.92 & 973 & 4.84 & 185 \\
\hline \multirow[t]{7}{*}{ MW11D } & $125-135$ & $4 / 4 / 07$ & 13.8 & 6.18 & 990 & - & - \\
\hline & & 11/19/07 & 13.1 & 7.22 & 987 & - & - \\
\hline & & $3 / 5 / 08$ & 6.0 & 7.06 & 872 & 6.85 & 252 \\
\hline & & 7/10/08 & 17.5 & 6.25 & 957 & 7.14 & 177 \\
\hline & & 10/23/08 & 12.3 & 7.11 & 863 & 8.71 & 123 \\
\hline & & $3 / 4 / 09$ & 14.3 & 7.23 & 848 & 4.47 & 27 \\
\hline & & $6 / 19 / 09$ & 17.4 & 6.96 & 885 & 5.92 & 131 \\
\hline \multirow[t]{7}{*}{ MW12S } & $43-53$ & $4 / 5 / 07^{a}$ & - & - & - & - & - \\
\hline & & $11 / 19 / 07^{a}$ & - & - & - & - & - \\
\hline & & $3 / 10 / 08^{a}$ & - & - & - & - & - \\
\hline & & $7 / 10 / 08^{a}$ & - & - & - & - & - \\
\hline & & $10 / 22 / 08^{a}$ & - & - & - & - & - \\
\hline & & 3/4/09a & - & - & - & - & - \\
\hline & & $6 / 19 / 09^{a}$ & 20.5 & 7.00 & 1436 & - & - \\
\hline
\end{tabular}


TABLE A.2 (Cont.)

\begin{tabular}{|c|c|c|c|c|c|c|c|}
\hline Well & $\begin{array}{l}\text { Screen Interval } \\
\quad(\mathrm{ft} B G L)\end{array}$ & $\begin{array}{l}\text { Sample } \\
\text { Date }\end{array}$ & $\begin{array}{l}\text { Temperature } \\
\left({ }^{\circ} \mathrm{C}\right)\end{array}$ & $\mathrm{pH}$ & $\begin{array}{l}\text { Conductivity } \\
(\mu \mathrm{S} / \mathrm{cm})\end{array}$ & $\begin{array}{c}\text { Dissolved } \\
\text { Oxygen } \\
\text { (mg/L) }\end{array}$ & $\begin{array}{r}\text { Reducti } \\
\text { Potenti } \\
(\mathrm{mV})\end{array}$ \\
\hline \multicolumn{8}{|c|}{ CCC/USDA wells installed during 2006-2007 investigation (cont.) } \\
\hline \multirow[t]{6}{*}{ MW12M } & $90-100$ & $\begin{array}{r}4 / 5 / 07 \\
11 / 19 / 07\end{array}$ & $\begin{array}{l}12.6 \\
14.9\end{array}$ & $\begin{array}{l}6.42 \\
7.13\end{array}$ & $\begin{array}{l}867 \\
835\end{array}$ & - & - \\
\hline & & $3 / 10 / 08$ & 12.6 & 7.13 & 665 & 1.81 & 212 \\
\hline & & 7/10/08 & 16.9 & 7.09 & 878 & 8.17 & 87 \\
\hline & & $10 / 22 / 08$ & 12.2 & 7.20 & 785 & 8.93 & 126 \\
\hline & & $3 / 4 / 09$ & 14.1 & 7.24 & 851 & 2.15 & 20 \\
\hline & & $6 / 19 / 09$ & 17.0 & 6.99 & 856 & 2.34 & 112 \\
\hline \multirow[t]{7}{*}{ MW12D } & $115-125$ & $4 / 5 / 07$ & 14.0 & 6.36 & 930 & - & - \\
\hline & & $11 / 18 / 07$ & 15.6 & 6.95 & 571 & - & - \\
\hline & & $3 / 9 / 08$ & 8.8 & 7.13 & 881 & 5.25 & 237 \\
\hline & & $7 / 11 / 08$ & 19.9 & 6.01 & 987 & 4.72 & 197 \\
\hline & & 10/22/08 & 12.3 & 7.09 & 873 & 7.96 & 136 \\
\hline & & $3 / 4 / 09$ & 14.4 & 7.25 & 923 & 4.06 & 21 \\
\hline & & $6 / 19 / 09$ & 16.4 & 6.96 & 895 & 5.08 & 150 \\
\hline \multirow[t]{7}{*}{ MW13S } & $112-122$ & $\begin{array}{r}4 / 5 / 07 \\
1 / 10 / 07\end{array}$ & 9.8 & 6.42 & 946 & - & - \\
\hline & & $11 / 19 / 07$ & 16.5 & 7.21 & 893 & - & - \\
\hline & & 3/10/08 & 12.2 & 7.13 & 810 & 6.21 & 199 \\
\hline & & $7 / 9 / 08$ & 17.4 & 6.99 & 875 & 7.72 & 116 \\
\hline & & 10/22/08 & 13.5 & 7.08 & 793 & 5.08 & 100 \\
\hline & & $3 / 4 / 09$ & 13.8 & 7.23 & 818 & 4.39 & 29 \\
\hline & & $6 / 18 / 09$ & 17.6 & 7.04 & 803 & 6.12 & 104 \\
\hline \multirow[t]{7}{*}{ MW13D } & $127-137$ & $4 / 5 / 07$ & 14.9 & 6.25 & 397 & - & - \\
\hline & & $11 / 19 / 07$ & 17.0 & 7.00 & 763 & - & - \\
\hline & & $3 / 9 / 08$ & 13.1 & 7.09 & 758 & 5.95 & 213 \\
\hline & & 7/9/08 & 18.6 & 7.07 & 848 & 18.1 & 57 \\
\hline & & $10 / 22 / 08$ & 13.3 & 7.06 & 824 & 5.28 & 98 \\
\hline & & $3 / 4 / 09$ & 14.5 & 7.19 & 833 & 4.01 & 25 \\
\hline & & $6 / 18 / 09$ & 17.5 & 6.93 & 828 & 5.60 & 117 \\
\hline \multirow[t]{7}{*}{ MW14S } & $108-118$ & $4 / 4 / 07$ & 13.4 & 6.50 & 704 & - & - \\
\hline & & 11/18/07 & 12.9 & 7.26 & 966 & - & - \\
\hline & & $3 / 8 / 08$ & 13.2 & 7.20 & 729 & 6.59 & 208 \\
\hline & & $7 / 10 / 08$ & 17.4 & 7.16 & 775 & 16.4 & 87 \\
\hline & & $10 / 22 / 08$ & 13.2 & 7.11 & 716 & 5.81 & 90 \\
\hline & & $3 / 4 / 09$ & 13.8 & 7.15 & 736 & 8.96 & 268 \\
\hline & & $6 / 18 / 09$ & 17.5 & 7.01 & 742 & 5.18 & 97 \\
\hline \multirow[t]{7}{*}{ MW14D } & $123-133$ & $4 / 4 / 07$ & 14.7 & 6.34 & 932 & - & - \\
\hline & & $11 / 18 / 07$ & 13.2 & 7.47 & 739 & - & - \\
\hline & & $3 / 8 / 08$ & 12.0 & 7.06 & 1424 & 1.95 & 282 \\
\hline & & 7/10/08 & 17.7 & 7.07 & 1459 & 14.5 & 86 \\
\hline & & $10 / 22 / 08$ & 13.0 & 7.00 & 1212 & 1.41 & 79 \\
\hline & & $3 / 5 / 09$ & 13.6 & 7.06 & 1339 & 2.15 & 69 \\
\hline & & $6 / 18 / 09$ & 19.8 & 7.04 & 1523 & 1.99 & 46 \\
\hline
\end{tabular}


TABLE A.2 (Cont.)

\begin{tabular}{|c|c|c|c|c|c|c|c|}
\hline Well & $\begin{array}{l}\text { Screen Interval } \\
\quad(\mathrm{ft} B G L)\end{array}$ & $\begin{array}{l}\text { Sample } \\
\text { Date }\end{array}$ & $\begin{array}{c}\text { Temperature } \\
\left({ }^{\circ} \mathrm{C}\right)\end{array}$ & $\mathrm{pH}$ & $\begin{array}{l}\text { Conductivity } \\
(\mu \mathrm{S} / \mathrm{cm})\end{array}$ & $\begin{array}{c}\text { Dissolved } \\
\text { Oxygen } \\
\text { (mg/L) }\end{array}$ & $\begin{array}{l}\text { Oxidation- } \\
\text { Reduction } \\
\text { Potential } \\
(\mathrm{mV})\end{array}$ \\
\hline \multicolumn{8}{|c|}{ CCC/USDA wells installed during 2006-2007 investigation (cont.) } \\
\hline \multirow[t]{7}{*}{ MW15S } & $88-98$ & $4 / 4 / 07$ & 13.1 & 8.03 & 854 & - & - \\
\hline & & 11/18/07 & 13.9 & NR & 1883 & - & - \\
\hline & & $3 / 10 / 08$ & 12.1 & 8.67 & 697 & 5.49 & 173 \\
\hline & & 7/12/08 & 14.0 & 8.88 & 660 & 11.6 & 94 \\
\hline & & $10 / 23 / 08$ & 13.0 & 8.00 & 789 & 5.27 & 67 \\
\hline & & $3 / 5 / 09$ & 15.7 & 8.78 & 589 & 7.48 & 163 \\
\hline & & $6 / 17 / 09$ & 18.2 & 9.13 & 386 & 4.84 & 62 \\
\hline \multirow[t]{7}{*}{ MW15D } & $105-115$ & $4 / 4 / 07$ & 14.8 & 6.15 & 2980 & - & - \\
\hline & & $11 / 18 / 07$ & 13.1 & 6.85 & 2190 & - & - \\
\hline & & $3 / 8 / 08$ & 9.0 & 6.85 & 2912 & 0.57 & 131 \\
\hline & & $7 / 12 / 08$ & 14.1 & 6.80 & 3067 & 1.05 & 90 \\
\hline & & $10 / 24 / 08$ & 13.0 & 6.81 & 2876 & 0.34 & 27 \\
\hline & & $3 / 5 / 09$ & 15.8 & 6.82 & 2945 & 0.41 & -15 \\
\hline & & $6 / 17 / 09$ & 18.6 & 6.71 & 2887 & 0.61 & 51 \\
\hline \multirow[t]{7}{*}{ MW16S } & $76-86$ & $4 / 4 / 07$ & 12.8 & 6.35 & 1708 & - & - \\
\hline & & $11 / 19 / 07$ & 15.0 & 6.94 & 1616 & - & - \\
\hline & & $3 / 7 / 08$ & 7.3 & 6.96 & 1968 & 3.45 & 184 \\
\hline & & 7/11/08 & 18.8 & 6.71 & 2883 & 1.13 & 52 \\
\hline & & $10 / 23 / 08$ & 11.6 & 7.01 & 1350 & 6.01 & 136 \\
\hline & & $3 / 5 / 09$ & 16.3 & 7.19 & 1505 & 2.49 & 12 \\
\hline & & 6/18/09 & 15.9 & 7.03 & 971 & 5.57 & 101 \\
\hline \multirow[t]{7}{*}{ MW16D } & $90-100$ & $4 / 4 / 07$ & 14.1 & 6.17 & 2910 & - & - \\
\hline & & $11 / 19 / 07$ & 12.5 & 6.78 & 2400 & - & - \\
\hline & & $3 / 7 / 08$ & 7.0 & 6.86 & 2866 & 0.50 & 140 \\
\hline & & 7/11/08 & 18.9 & 6.64 & 3134 & 0.41 & 32 \\
\hline & & $10 / 23 / 08$ & 11.3 & 6.79 & 2791 & 0.45 & 37 \\
\hline & & $3 / 5 / 09$ & 15.6 & 6.94 & 2926 & 0.27 & 14 \\
\hline & & $6 / 18 / 09$ & 18.3 & 6.77 & 2867 & 0.30 & 46 \\
\hline \multirow[t]{7}{*}{ MW17 } & $120-130$ & $4 / 4 / 07$ & 16.0 & 6.44 & 861 & - & - \\
\hline & & $11 / 19 / 07$ & 8.3 & 7.15 & 610 & - & - \\
\hline & & $3 / 5 / 08$ & 5.5 & 7.12 & 804 & 7.02 & 239 \\
\hline & & 7/9/08 & 17.5 & 7.11 & 843 & 20.6 & 89 \\
\hline & & $10 / 22 / 08$ & 13.1 & 7.10 & 777 & 8.35 & 110 \\
\hline & & $3 / 4 / 09$ & 14.1 & 7.12 & 823 & 8.47 & 258 \\
\hline & & $6 / 17 / 09$ & 18.4 & 7.01 & 825 & 5.65 & 103 \\
\hline \multicolumn{8}{|c|}{ Private wells } \\
\hline \multirow[t]{6}{*}{ Oentrich } & 150 & 7/20/06 & - & - & - & - & - \\
\hline & & $8 / 2 / 06$ & - & - & - & - & - \\
\hline & & $4 / 5 / 07$ & _- & - & - & - & - \\
\hline & & $11 / 19 / 07$ & 12.1 & 8.26 & 1830 & - & - \\
\hline & & $3 / 6 / 08$ & - & - & - & - & - \\
\hline & & $7 / 11 / 08$ & - & - & - & - & - \\
\hline
\end{tabular}


TABLE A.2 (Cont.)

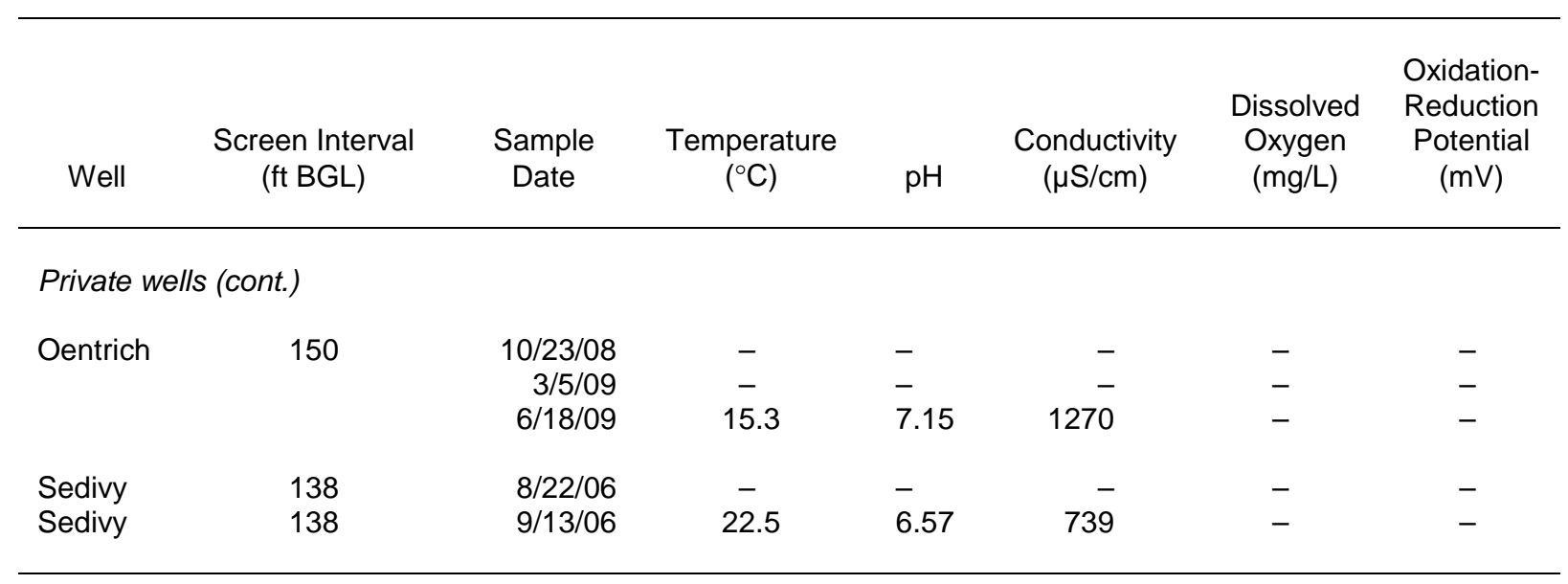

a Not sampled; well dry. 


\section{Appendix B:}

Results from the AGEM Laboratory for Dual Analyses of Samples Collected at Barnes in March and June 2009 and for Quality Control Samples 
TABLE B.1 Analytical results for samples and replicates collected at Barnes in March and June 2009 and for quality control samples.

\begin{tabular}{|c|c|c|c|c|c|c|c|}
\hline \multirow[b]{2}{*}{$\begin{array}{c}\text { Sample } \\
\text { Date }\end{array}$} & \multirow[b]{2}{*}{ Location } & \multirow[b]{2}{*}{$\begin{array}{c}\text { Depth } \\
\text { (ft BGL) }\end{array}$} & \multirow[b]{2}{*}{ Sample } & \multirow[b]{2}{*}{ Analysis Type } & \multicolumn{3}{|c|}{ Concentration $(\mu \mathrm{g} / \mathrm{L})$} \\
\hline & & & & & $\begin{array}{c}\text { Carbon } \\
\text { Tetrachloride }\end{array}$ & Chloroform & $\begin{array}{c}\text { Methylene } \\
\text { Chloride }\end{array}$ \\
\hline \multicolumn{8}{|c|}{ March 2009 sampling } \\
\hline $3 / 4 / 09$ & MW3D & 133.02-152.73 & BAMW3D-W-22705 & Primary & $N D^{a}$ & ND & ND \\
\hline $3 / 4 / 09$ & MW3D & $133.02-152.73$ & BAMW3DDUP-W-28632 & Replicate & ND & ND & ND \\
\hline $3 / 5 / 09$ & MW9 & $100-110$ & BAMW9-W-22712 & Primary & 2.3 & ND & ND \\
\hline $3 / 5 / 09$ & MW9 & $100-110$ & BAMW9DUP-W-28638 & Replicate & 2.1 & ND & ND \\
\hline $3 / 5 / 09$ & MW10S & $93-103$ & BAMW10S-W-22713 & Primary & 49 & 2.1 & ND \\
\hline $3 / 5 / 09$ & MW10S & $93-103$ & BAMW10SDUP-W-28631 & Replicate & 52 & 2.3 & ND \\
\hline $3 / 4 / 09$ & MW11S & $40-50$ & BAMW11S-W-22715 & Primary & ND & ND & ND \\
\hline $3 / 4 / 09$ & MW11S & $40-50$ & BAMW11SDUP-W-28630 & Replicate & ND & ND & ND \\
\hline $3 / 4 / 09$ & MW12M & $90-100$ & BAMW12M-W-22719 & Primary & 25 & 4.4 & ND \\
\hline $3 / 4 / 09$ & MW12M & $90-100$ & BAMW12M-W-22719DUP & Duplicate & 25 & 4.7 & ND \\
\hline $3 / 5 / 09$ & Oentrich & 150 & BAOENTRICH-W-28627 & Primary & 1.1 & ND & ND \\
\hline $3 / 5 / 09$ & Oentrich & 150 & BAOENTRICH-28627DUP & Duplicate & 1.1 & ND & ND \\
\hline $3 / 4 / 09$ & QC & - & BAQCIR-W-28634 & Rinsate after MW2D & ND & ND & ND \\
\hline $3 / 5 / 09$ & QC & - & BAQCTB-W-28637 & Trip blank & ND & ND & ND \\
\hline $3 / 6 / 09$ & QC & - & BAQCTB-W-28635 & Trip blank & ND & ND & ND \\
\hline \multicolumn{8}{|c|}{ June 2009 sampling } \\
\hline $6 / 18 / 09$ & MW13D & $127-137$ & BAMW13D-W-28658 & Primary & 6.2 & ND & ND \\
\hline $6 / 18 / 09$ & MW13D & $127-137$ & BAMW13D-W-28658DUP & Duplicate & 6.7 & ND & ND \\
\hline $6 / 18 / 09$ & MW14D & $123-133$ & BAMW14D-W-28660 & Primary & ND & ND & ND \\
\hline $6 / 18 / 09$ & MW14D & $123-133$ & BAMW14D-W-28660DUP & Duplicate & ND & ND & ND \\
\hline $6 / 18 / 09$ & MW16D & $90-100$ & BAMW16D-W-28664 & Primary & ND & ND & ND \\
\hline $6 / 18 / 09$ & MW16D & $90-100$ & BAMW16DDUP-W-28671 & Replicate & ND & ND & ND \\
\hline
\end{tabular}


TABLE B.1 (Cont.)

\begin{tabular}{|c|c|c|c|c|c|c|c|}
\hline \multirow[b]{2}{*}{$\begin{array}{c}\text { Sample } \\
\text { Date }\end{array}$} & \multirow[b]{2}{*}{ Location } & \multirow[b]{2}{*}{$\begin{array}{c}\text { Depth } \\
\text { (ft BGL) }\end{array}$} & \multirow[b]{2}{*}{ Sample } & \multirow[b]{2}{*}{ Analysis Type } & \multicolumn{3}{|c|}{ Concentration $(\mu \mathrm{g} / \mathrm{L})$} \\
\hline & & & & & $\begin{array}{c}\text { Carbon } \\
\text { Tetrachloride }\end{array}$ & Chloroform & $\begin{array}{c}\text { Methylene } \\
\text { Chloride }\end{array}$ \\
\hline \multicolumn{8}{|c|}{ June 2009 sampling (cont.) } \\
\hline $6 / 17 / 09$ & MW17 & $120-130$ & BAMW17-W-28665 & Primary & 1.0 & ND & ND \\
\hline $6 / 17 / 09$ & MW17 & $120-130$ & BAMW17DUP-W-28669 & Replicate & $0.9 \mathrm{Jb}$ & ND & ND \\
\hline $6 / 18 / 09$ & MW6D & $105-115$ & BAMW6D-W-28645 & Primary & 1.5 & ND & ND \\
\hline $6 / 18 / 09$ & MW6D & $105-115$ & BAMW6DDUP-W-28670 & Replicate & 1.4 & ND & ND \\
\hline $6 / 18 / 09$ & MW6D & $105-115$ & BAMW6D-W-28645DUP & Duplicate & 1.5 & ND & ND \\
\hline $6 / 18 / 09$ & QC & - & BAQCIR-W-28672 & Rinsate after MW14S & ND & ND & ND \\
\hline $6 / 19 / 09$ & QC & - & BAQCIR-W-28673 & Rinsate after MW12D & ND & ND & ND \\
\hline $6 / 18 / 09$ & QC & - & BAQCTB-W-28674 & Trip blank & ND & ND & ND \\
\hline $6 / 19 / 09$ & QC & - & BAQCTB-W-28675 & Trip blank & ND & ND & ND \\
\hline $6 / 19 / 09$ & QC & - & BAQCTB-W-28676 & Trip blank & ND & ND & ND \\
\hline
\end{tabular}

a ND, contaminant not detected at an instrument detection limit of $0.1 \mu \mathrm{g} / \mathrm{L}$.

b Qualifier J indicates an estimated concentration below the method quantitation limit of $1.0 \mu \mathrm{g} / \mathrm{L}$. 


\section{Appendix C:}

Sample Documentation from TestAmerica Laboratories, Inc. 


\section{TestAmerica}

THE LEADER IN ENVIRONMENTAL TESTING

TestAmerica Laboratories, Inc.

March 23, 2009

Mr. Clyde Dennis

Argonne National Laboratory

9700 S. Cass Avenue,

Bldg. 203, Office B149

Argonne, IL 60439

Re: Laboratory Project No. 21005

Case: BARNES; SDG: 130491

Dear Mr. Dennis:

Enclosed are analytical results for samples that were received by TestAmerica Burlington on March $6^{\text {th }}, 2009$. Laboratory identification numbers were assigned, and designated as follows:

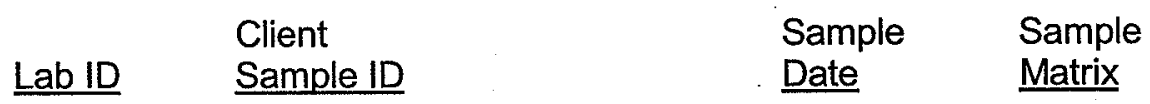

Received: 03/06/09 ETR No: 130491

$\begin{array}{llll}787275 & \text { BAMW1D-W-22703 } & 03 / 04 / 09 & \text { WATER } \\ 787276 & \text { BAMW12M-W-22719 } & 03 / 04 / 09 & \text { WATER } \\ 787277 & \text { BAMW10D-W-22714 } & 03 / 05 / 09 & \text { WATER } \\ 787278 & \text { BAMW14D-W-28621 } & 03 / 05 / 09 & \text { WATER } \\ 787279 & \text { BAQCTB-W-28637 } & 03 / 05 / 09 & \text { WATER } \\ 787280 & \text { VHBLK01 } & 03 / 06 / 09 & \text { WATER }\end{array}$

Documentation of the condition of the samples at the time of their receipt and any exception to the laboratory's Sample Acceptance Policy is documented in the Sample Handling section of this submittal. The samples, as received, were not acid preserved. On that basis, the laboratory attempted to provide for the analytical work to be performed within seven days of sample collection. The analysis of each sample in the sample set did occur on the eleventh day from the date that the samples were collected.

In order to accommodate field length limitations in processing the data summary forms, the laboratory did, in certain instances, abbreviate the sample identifier. The electronically formatted data provides for the full sample identifier. 


\section{TestAmerica}

THE LEADER IN ENVIRONMENTAL TESTING

\section{SOM01.2 Volatile Organics (Trace Level Water)}

A storage blank was prepared for volatile organics analysis, and stored in association with the storage of the samples. That storage blank, identified as VHBLK01, was carried through the holding period with the samples, and analyzed.

Sample BAMW12M-W-22719 was analyzed at a dilution, based on the results of preliminary screening. An additional, more concentrated analysis was performed on the sample in order to provide a lower reporting limit for those target analytes that were not identified as constituents in the primary analysis. Both sets of results for the analysis of sample BAMW12M-W-22719 are included in this submittal. Each of the analyses associated with the sample set exhibited an acceptable internal standard performance. There was an acceptable recovery of each deuterated monitoring compound (DMC) in each analysis associated with the sample set. Matrix spike and matrix spike duplicate analyses were not performed on the samples in this sample set. The analysis of the method blank associated with the analytical work was free of target analyte contamination, as was the analysis of the instrument blank following the more concentrated analysis of sample BAMW12M-W-22719, and the analysis of the storage blank associated with the sample set. Present in the storage blank and method blank analyses was a non-target constituent that represented a compound that is related to the DMC formulation. The fact that the presence of this compound is not within the laboratory's control is at issue. The derived results for that compound have been qualified with an " $X$ " qualifier to reflect the source of the contamination.

The responses for each target analyte met the relative standard deviation criterion in the initial calibration. The response for each target analyte met the 50.0 percent difference criterion in the closing calibration check acquisition.

The primary quantitation mass for methylcyclohexane that is specified in the Statement of Work is mass 83 . The laboratory did identify a contribution to mass 83 from 1,2-dichloropropane- $d_{6}$, one of the deuterated monitoring compounds (DMCs). The laboratory did change the primary quantitation mass assignment to mass 55 for the quantification of methylcyclohexane.

Manual integration was employed in deriving certain of the analytical results. The values that have been derived from manual integration are qualified on the quantitation reports. Extracted ion current profiles for each manual integration are included in the data package, and further documented in the Sample Preparation section of this submittal.

Any reference within this report to Severn Trent Laboratories, Inc. or STL, should be understood to refer to TestAmerica Laboratories, Inc. (formerly known as Severn Trent Laboratories, Inc.) The analytical results associated with the samples presented in this test report were generated under a quality system that adheres to requirements specified in the NELAC standard. Release of the data in this test report and any associated electronic deliverables is authorized by the Laboratory Director's designee as verified by the following signature. 


\section{TestAmerica \\ THE LEADERIN ENVIRONMENTAL TESTING}

If there are any questions regarding this submittal, please contact me at 802 660-1990.

Sincerely,

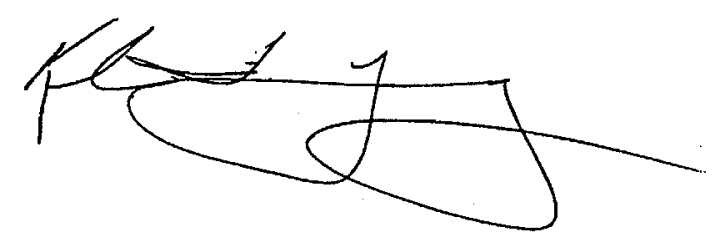

Kirk F. Young

Project Manager

KFY/hsf

Enclosure 


\section{TestAmerica Burlington Data Qualifier Definitions}

\section{Organic}

$\mathrm{U}$ : Compound analyzed but not detected at a concentration above the reporting limit.

$\mathrm{J}: \quad$ Estimated value.

$\mathrm{N}$ : Indicates presumptive evidence of a compound. This flag is used only for tentatively identified compounds (TICs) where the identification of a compound is based on a mass spectral library search.

P: $\quad$ SW-846: The relative percent difference for detected concentrations between two GC columns is greater than $40 \%$. Unless otherwise specified the higher of the two values is reported on the Form I.

CLP SOW: Greater than 25\% difference for detected concentrations between two GC columns. Unless otherwise specified the lower of the two values is reported on the Form I.

C: $\quad$ Pesticide result whose identification has been confirmed by GC/MS.

B: Analyte is found in the sample and the associated method blank. The flag is used for tentatively identified compounds as well as positively identified compounds.

E: Compounds whose concentrations exceed the upper limit of the calibration range of the instrument for that specific analysis.

D: Concentrations identified from analysis of the sample at a secondary dilution.

A: Tentatively identified compound is a suspected aldol condensation product.

$X, Y, Z$ : Laboratory defined flags that may be used alone or combined, as needed. If used, the description of the flag is defined in the project narrative.

\section{Inorganic/Metals}

E: $\quad$ Reported value is estimated due to the presence of interference.

$\mathrm{N}: \quad$ Matrix spike sample recovery is not within control limits.

* Duplicate sample analysis is not within control limits.

B: The result reported is less than the reporting limit but greater than the instrument detection limit.

U: Analyte was analyzed for but not detected above the reporting limit.

Method Codes:

P ICP-AES

MS ICP-MS

CV. Cold Vapor AA

AS Semi-Automated Spectrophotometric 


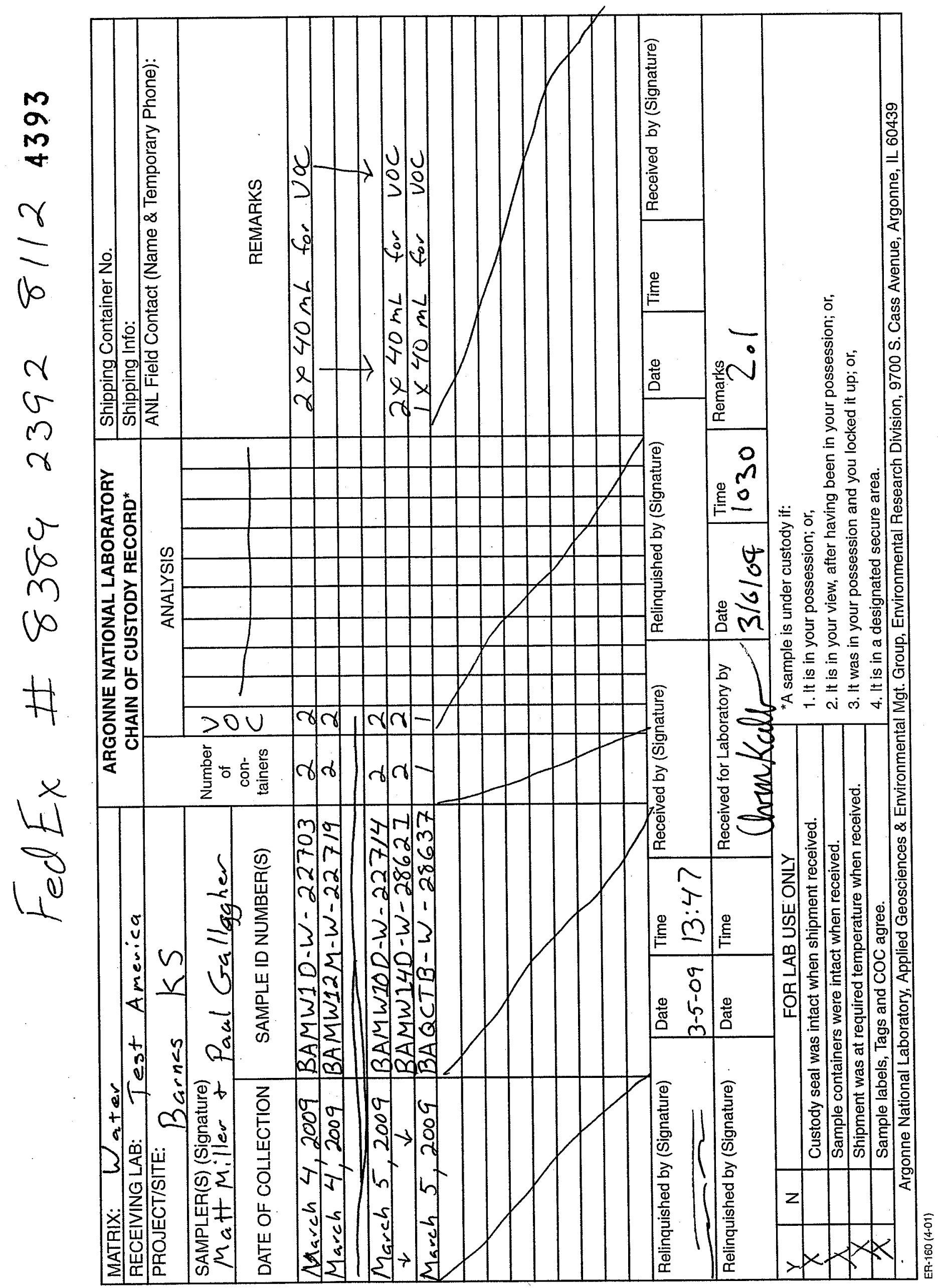




\section{TestAmerica}

THE LEADER IN ENVIRONMENTAL TESTING

\section{Sample Data Summary - SOM01.2 Volatiles - Trace}


Lab Name: TESTAMERICA BURLINGTON

Lab Code: STLV
Case No.: BARNES

Matrix: (SOIL/SED/WATER) Water

Sample wt/vol: 25.0

$(\mathrm{g} / \mathrm{mL}) \mathrm{mL}$

Level: (TRACE/LOW/MED) TRACE

$\%$ Moisture: not dec.

GC Column: DB-624

Soil Extract Volume:

ID $: 0.53$

(mm)

(uL)

Contract: 8E-00302

Mod. Ref No.:

Lab Sample ID: 787275

Lab File ID: 787275

Dilution Factor: 1.0

Soil Aliquot Volume:
SDG No.: 130491

Purge Volume: 25.0

Date Received: 03/06/2009

Date Analyzed: 03/10/2009

(uL)

(mL)

\begin{tabular}{|c|c|c|c|}
\hline CAS NO. & COMPOUND & $\begin{array}{l}\text { CONCENTRATION UNITS: } \\
(\mathrm{ug} / \mathrm{L} \text { or } \mathrm{ug} / \mathrm{kg}) \mathrm{ug} / \mathrm{L}\end{array}$ & $Q$ \\
\hline$========== \pm$ & 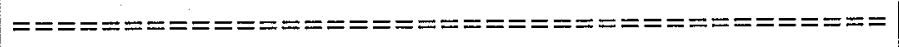 & 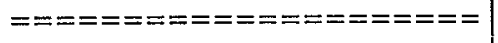 & $=======$ \\
\hline $75-71-8$ & Dichlorodifluoromethane & 0.50 & $\mathrm{U}$ \\
\hline $74-87-3$ & Chloromethane & 0.50 & $\mathrm{U}$ \\
\hline $75-01-4$ & Vinyl chloride & 0.50 & U \\
\hline $74-83-9$ & Bromomethane & 0.50 & $\mathrm{U}$ \\
\hline $75-00-3$ & Chloroethane & 0.50 & $\mathrm{U}$ \\
\hline $75-69-4$ & Trichlorofluoromethane & 0.50 & $\mathrm{U}$ \\
\hline $75-35-4$ & 1,1-Dichloroethene & 0.50 & $\mathrm{U}$ \\
\hline $76-13-1$ & $1,1,2$-Trichloro-1,2,2-trifluoroethane & 0.50 & $\mathrm{U}$ \\
\hline $67-64-1$ & Acetone & 5.0 & $\mathrm{U}$ \\
\hline $75-15-0$ & Carbon disulfide & 0.50 & $\mathrm{U}$ \\
\hline $79-20-9$ & Methyl acetate & 0.50 & $\mathrm{U}$ \\
\hline $75-09-2$ & Methylene chloride & 0.50 & $\mathrm{U}$ \\
\hline $156-60-5$ & trans-1,2-Dichloroethene & 0.50 & $\mathrm{U}$ \\
\hline $1634-04-4$ & Methyl tert-butyl ether & 0.50 & $\mathrm{U}$ \\
\hline $75-34-3$ & 1,1-Dichloroethane & 0.50 & $\mathrm{U}$ \\
\hline $156-59-2$ & cis-1,2-Dichloroethene & 0.50 & $\mathrm{U}$ \\
\hline $78-93-3$ & 2-Butanone & 5.0 & $\mathrm{U}$ \\
\hline $74-97-5$ & Bromochloromethane & 0.50 & $\mathrm{U}$ \\
\hline $67-66-3$ & Chloroform & 0.50 & U \\
\hline $71-55-6$ & $1,1,1$-Trichloroethane & 0.50 & $\mathrm{U}$ \\
\hline $110-82-7$ & Cyclohexane & 0.50 & $\mathrm{U}$ \\
\hline $56-23-5$ & Carbon tetrachloride & 0.22 & $\mathrm{~J}$ \\
\hline $71-43-2$ & Benzene & 0.50 & U \\
\hline $107-06-2$ & 1,2-Dichloroethane & 0.50 & $\mathrm{U}$ \\
\hline
\end{tabular}

Report 1,4-Dioxane for Low-Medium VOA analysis only 
Lab Name: TESTAMERICA BURIINGTON

Lab Code: STLV Case No.: BARNES

Matrix: (SOIL/SED/WATER) water

Sample wt/vol: $25.0 \quad(\mathrm{~g} / \mathrm{mL}) \mathrm{mL}$

Level: (TRACE/LOW/MED) TRACE

\% Moisture: not dec.

GC Column: DB-624

Soil Extract Volume:

ID : 0.53

(mm)

(uL)

Contract: 8E-00302

Mod. Ref No.:

Lab Sample ID: 787275

Lab File ID: 787275
SDG NO.: 130491

Purge Volume: 25.0

Date Received: 03/06/2009

Date Analyzed: 03/10/2009

(mL)

\begin{tabular}{|c|c|c|c|}
\hline CAS NO. & COMPOUND & $\begin{array}{l}\text { CONCENTRATION UNITS: } \\
(\mathrm{ug} / \mathrm{L} \text { or } \mathrm{ug} / \mathrm{kg}) \mathrm{ug} / \mathrm{L}\end{array}$ & Q \\
\hline$==========1$ & 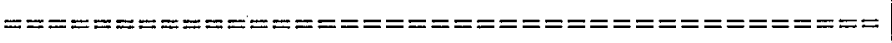 & 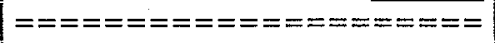 & $========$ \\
\hline $79-01-6$ & Trichloroethene & 0.50 & U \\
\hline $108-87-2$ & Methylcyclohexane & 0.50 & $\mathrm{U}$ \\
\hline $78-87-5$ & 1,2-Dichloropropane & 0.50 & $\mathrm{U}$ \\
\hline $75-27-4$ & Bromodichloromethane & 0.50 & $\mathrm{U}$ \\
\hline $10061-01-5$ & Cis-1,3-Dichloropropene & 0.50 & $\mathrm{U}$ \\
\hline $108-10-1$ & 4-Methyl-2-pentanone & 5.0 & $\mathrm{U}$ \\
\hline $108-88-3$ & Toluene & 0.35 & $\mathrm{~J}$ \\
\hline $10061-02-6$ & trans-1,3-Dichloropropene & 0.50 & U \\
\hline $79-00-5$ & 1,1,2-Trichloroethane & 0.50 & $\mathrm{U}$ \\
\hline $127-18-4$ & Tetrachloroethene & 0.50 & $\mathrm{U}$ \\
\hline $591-78-6$ & 2-Hexanone & 5.0 & $\mathrm{U}$ \\
\hline $124-48-1$ & Dibromochloromethane & 0.50 & $\mathrm{U}$ \\
\hline $106-93-4$ & 1,2-Dibromoethane & 0.50 & $\mathrm{U}$ \\
\hline $108-90-7$ & Chlorobenzene & 0.50 & $\mathrm{U}$ \\
\hline $100-41-4$ & Ethylbenzene & 0.50 & $\mathrm{U}$ \\
\hline $95-47-6$ & o-Xylene & 0.50 & $\mathrm{U}$ \\
\hline $179601-23-1$ & $\mathrm{~m}, \mathrm{p}$-Xylene & 0.50 & $\mathrm{U}$ \\
\hline $100-42-5$ & Styrene & 0.50 & $\mathrm{U}$ \\
\hline $75-25-2$ & Bromoform & 0.50 & $\mathrm{U}$ \\
\hline $98-82-8$ & Isopropylbenzene & 0.50 & $\mathrm{U}$ \\
\hline $79-34-5$ & $1,1,2,2$-Tetrachloroethane & 0.50 & U \\
\hline $541-73-1$ & 1,3-Dichlorobenzene & 0.50 & $\mathrm{U}$ \\
\hline $106-46-7$ & 1,4-Dichlorobenzene & 0.50 & U \\
\hline $95-50-1$ & 1,2-Dichlorobenzene & 0.50 & $\mathrm{U}$ \\
\hline $96-12-8$ & 1,2-Dibromo-3-chloropropane & 0.50 & $\mathrm{U}$ \\
\hline $120-82-1$ & 1,2,4-Trichlorobenzene & 0.50 & $\mathrm{U}$ \\
\hline $87-61-6$ & 1,2,3-Trichlorobenzene & 0.50 & $\mathrm{U}$ \\
\hline
\end{tabular}


Lab Name: TESTAMERICA BURLINGTON

Lab Code: STLV Case No.: BARNES

Matrix: (SOIL/SED/WATER) Water

Sample wt/vol: 25.0

$(\mathrm{g} / \mathrm{mL}) \mathrm{mL}$

Leve1: (TRACE/LOW/MED) TRACE

\% Moisture: not dec.

GC Column: DB-624

ID $: 0.53$

Soil Extract Volume:

Purge Volume: 25.0
Contract : 8E-00302

Mod. Ref No.:
SDG No.: 130491
Lab Sample ID: 787276

Lab File ID: 787276

Date Received: 03/06/2009

Date Analyzed: 03/10/2009

Dilution Factor: 1.0

Soil Aliquot Volume:

(mL)

\begin{tabular}{|c|c|c|c|}
\hline CAS NO. & COMPOUND & $\begin{array}{l}\text { CONCENTRATION UNITS: } \\
(\mathrm{ug} / \mathrm{L} \text { or } \mathrm{ug} / \mathrm{kg}) \mathrm{ug} / \mathrm{L}\end{array}$ & Q \\
\hline$==========$ & 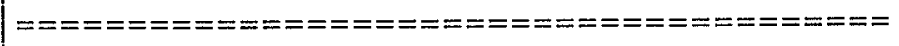 & 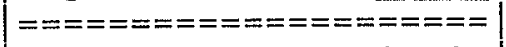 & $=======$ \\
\hline $75-71-8$ & Dichlorodifluoromethane & 0.50 & $\mathrm{U}$ \\
\hline $74-87-3$ & Chloromethane & 0.50 & $\mathrm{U}$ \\
\hline $75-01-4$ & Vinyl chloride & 0.50 & $\mathrm{U}$ \\
\hline $74-83-9$ & Bromomethane & 0.50 & $\mathrm{U}$ \\
\hline $75-00-3$ & Chloroethane & 0.50 & $\mathrm{U}$ \\
\hline $75-69-4$ & Trichlorofluoromethane & 0.50 & $\mathrm{U}$ \\
\hline $75-35-4$ & 1,1 -Dichloroethene & 0.50 & $U$ \\
\hline $76-13-1$ & $1,1,2$-Trichloro-1,2,2-trifluoroethane & 0.50 & $\mathrm{U}$ \\
\hline $67-64-1$ & Acetone & 5.0 & $\mathrm{U}$ \\
\hline $75-15-0$ & Carbon disulfide & 0.50 & $\mathrm{U}$ \\
\hline $79-20-9$ & Methyl acetate & 0.50 & $\mathrm{U}$ \\
\hline $75-09-2$ & Methylene chloride & 0.50 & $\mathrm{U}$ \\
\hline $156-60-5$ & trans-1,2-Dichloroethene & 0.50 & $\mathrm{U}$ \\
\hline $1634-04-4$ & Methyl tert-butyl ether & 0.50 & $\mathrm{U}$ \\
\hline $75-34-3$ & 1,1-Dichloroethane & 0.50 & $\mathrm{U}$ \\
\hline $156-59-2$ & cis-1,2-Dichloroethene & 0.50 & $\mathrm{U}$ \\
\hline $78-93-3$ & 2-Butanone & 5.0 & $\mathrm{U}$ \\
\hline $74-97-5$ & Bromochloromethane & 0.50 & $\mathrm{U}$ \\
\hline $67-66-3$ & Chloroform & 4.6 & \\
\hline $71-55-6$ & 1,1,1-Trichloroethane & 0.50 & $\bar{U}$ \\
\hline $110-82-7$ & Cyclohexane & 0.50 & $\mathrm{U}$ \\
\hline $56-23-5$ & Carbon tetrachloride & 21 & $\mathrm{E}$ \\
\hline $71-43-2$ & Benzene & 0.50 & $\mathrm{U}$ \\
\hline $107-06-2$ & 1,2-Dichloroethane & 0.50 & $\mathrm{U}$ \\
\hline
\end{tabular}

Report 1,4-Dioxane for Low-Medium VOA analysis only 
Lab Name: TESTAMERICA BURLINGTON

Lab Code: STLV

Case No.: BARNES

Matrix: (SOIL/SED/WATER) Water

Sample wt/vol: $25.0 \quad(\mathrm{~g} / \mathrm{mL}) \mathrm{mL}$

Level: (TRACE/LOW/MED) TRACE

\% Moisture: not dec.

GC Column: DB-624

ID : 0.53

$(\mathrm{mm})$

(uL)

Contract: $8 \mathrm{E}-00302$

Mod. Ref No.:
SDG No.: 130491
Soil Extract Volume:

Purge Volume: 25.0
Lab Sample ID: 787276

Lab File ID: 787276

Date Received: 03/06/2009

Date Analyzed: 03/10/2009

Dilution Factor: 1.0

Soil Aliquot Volume:

(uL)

\begin{tabular}{|c|c|c|c|}
\hline CAS NO. & COMPOUND & $\begin{array}{l}\text { CONCENTRATION UNITS: } \\
(\mathrm{ug} / \mathrm{L} \text { or } \mathrm{ug} / \mathrm{kg}) \mathrm{ug} / \mathrm{L}\end{array}$ & $\mathrm{Q}$ \\
\hline 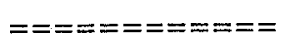 & 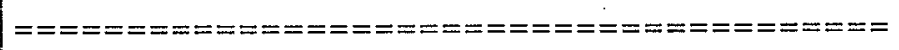 & 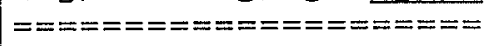 & $=======$ \\
\hline $79-01-6$ & Trichloroethene & 0.50 & U \\
\hline $108-87-2$ & Methylcyclohexane & 0.50 & $\mathrm{U}$ \\
\hline $78-87-5$ & 1,2-Dichloropropane & 0.50 & $\mathrm{U}$ \\
\hline $75-27-4$ & Bromodichloromethane & 0.50 & $\mathrm{U}$ \\
\hline $10061-01-5$ & cis-1,3-Dichloropropene & 0.50 & $\mathrm{U}$ \\
\hline $108-10-1$ & 4-Methyl-2-pentanone & 5.0 & $\mathrm{U}$ \\
\hline $108-88-3$ & Toluene & 0.50 & $\mathrm{U}$ \\
\hline $10061-02-6$ & trans-1,3-Dichloropropene & 0.50 & $\mathrm{U}$ \\
\hline $79-00-5$ & 1,1,2-Trichloroethane & 0.50 & $\mathrm{U}$ \\
\hline $127-18-4$ & Tetrachloroethene & 0.50 & $\mathrm{U}$ \\
\hline $591-78-6$ & 2 -Hexanone & 5.0 & $\mathrm{U}$ \\
\hline $124-48-1$ & Dibromochloromethane & 0.50 & $\mathrm{U}$ \\
\hline $106-93-4$ & 1,2-Dibromoethane & 0.50 & $\mathrm{U}$ \\
\hline $108-90-7$ & Chlorobenzene & 0.50 & $\mathrm{U}$ \\
\hline $100-41-4$ & Ethylbenzene & 0.50 & $\mathrm{U}$ \\
\hline $95-47-6$ & o-Xylene & 0.50 & U \\
\hline $179601-23-1$ & $\mathrm{~m}, \mathrm{p}$-Xylene & 0.50 & U \\
\hline $100-42-5$ & styrene & 0.50 & $\mathrm{U}$ \\
\hline $75-25-2$ & Bromoform & 0.50 & $\mathrm{U}$ \\
\hline $98-82-8$ & Isopropylbenzene & 0.50 & $\mathrm{U}$ \\
\hline $79-34-5$ & $1,1,2,2$-Tetrachloroethane & 0.50 & $\mathrm{U}$ \\
\hline $541-73-1$ & 1,3-Dichlorobenzene & 0.50 & $\mathrm{U}$ \\
\hline $106-46-7$ & 1,4-Dichlorobenzene & 0.50 & $\mathrm{U}$ \\
\hline $95-50-1$ & 1,2-Dichlorobenzene & 0.50 & $\mathrm{U}$ \\
\hline $96-12-8$ & 1,2-Dibromo-3-chloropropane & 0.50 & $\mathrm{U}$ \\
\hline $120-82-1$ & $1,2,4$-Trichlorobenzene & 0.50 & U \\
\hline $87-61-6$ & $1,2,3$-Trichlorobenzene & 0.50 & $\mathrm{U}$ \\
\hline
\end{tabular}


$1 A$ - FORM I VOA-1

VOLATILE ORGANICS ANALYSIS DATA SHEET
EPA SAMPLE NO

BAMW12M719DL
Lab Name: TESTAMERICA BURLINGTON

Lab Code: STLV Case No.: BARNES

Matrix: (SOIL/SED/WATER) water

Sample wt/vol: 25.0

$(\mathrm{g} / \mathrm{mL}) \mathrm{mL}$

Leve1: (TRACE/LOW/MED) TRACE

\% Moisture: not dec.

GC Column: DB-624

Soil Extract Volume:

ID $: 0.53$

$(\mathrm{mm})$

(uI)

Contract: 8E-00302

Mod. Ref No. :

Lab File ID: $787276 \mathrm{D}$

Dilution Factor: 2.0

Soil Aliquot Volume:
SDG No.: 130491

Purge Volume: 25.0

Lab Sample ID: 787276D1

Date Received: 03/06/2009

Date Analyzed: 03/10/2009

(uL)

(mL)

\begin{tabular}{|c|c|c|c|}
\hline CAS NO. & COMPOUND & $\begin{array}{l}\text { CONCENTRATION UNITS: } \\
(\mathrm{ug} / \mathrm{L} \text { or } \mathrm{ug} / \mathrm{kg}) \mathrm{ug} / \mathrm{L}\end{array}$ & Q \\
\hline$==========$ & 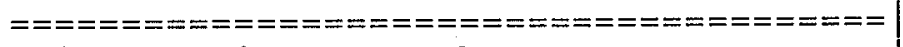 & 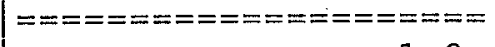 & $========$ \\
\hline $75-71-8$ & Dichlorodifluoromethane & 1.0 & $\mathrm{U}$ \\
\hline $74-87-3$ & Chloromethane & 1.0 & U \\
\hline $75-01-4$ & Vinyl chloride & 1.0 & $\mathrm{U}$ \\
\hline $74-83-9$ & Bromomethane & 1.0 & $\mathrm{U}$ \\
\hline $75-00-3$ & Chloroethane & 1.0 & $\mathrm{U}$ \\
\hline $75-69-4$ & Trichlorofluoromethane & 1.0 & $\mathrm{U}$ \\
\hline $75-35-4$ & 1,1-Dichloroethene & 1.0 & $\mathrm{U}$ \\
\hline $76-13-1$ & $1,1,2$-Trichloro-1,2,2-trifluoroethane & 1.0 & $\mathrm{U}$ \\
\hline $67-64-1$ & Acetone & 19 & $\mathrm{D}$ \\
\hline $75-15-0$ & Carbon disulfide & 1.0 & $\mathrm{U}$ \\
\hline $79-20-9$ & Methyl acetate & 1.0 & $\mathrm{U}$ \\
\hline $75-09-2$ & Methylene chloride & 1.0 & U \\
\hline $156-60-5$ & trans-1,2-Dichloroethene & 1.0 & $\mathrm{U}$ \\
\hline $1634-04-4$ & Methyl tert-butyl ether & 1.0 & $\mathrm{U}$ \\
\hline $75-34-3$ & 1,1-Dichloroethane & 1.0 & $\mathrm{U}$ \\
\hline $156-59-2$ & cis-1,2-Dichloroethene & 1.0 & $\mathrm{U}$ \\
\hline $78-93-3$ & 2-Butanone & 10 & $\mathrm{U}$ \\
\hline $74-97-5$ & Bromochloromethane & 1.0 & $\mathrm{U}$ \\
\hline $67-66-3$ & Chloroform & 4.0 & $\mathrm{D}$ \\
\hline $71-55-6$ & 1,1,1-Trichloroethane & 1.0 & $\mathrm{U}$ \\
\hline $110-82-7$ & Cyclohexane & 1.0 & $\mathrm{U}$ \\
\hline $56-23-5$ & Carbon tetrachloride & 15 & $\mathrm{D}$ \\
\hline $71-43-2$ & Benzene & 1.0 & $\mathrm{U}$ \\
\hline $107-06-2$ & 1,2-Dichloroethane & 1.0 & $\mathrm{U}$ \\
\hline
\end{tabular}

Report 1,4-Dioxane for Low-Medium VOA analysis only 
Lab Name: TESTAMERICA BURLINGTON

Lab Code: STLV

Case No.: BARNES

Matrix: (SOIL/SED/WATER) Water

Sample wt/vol: 25.0

$(\mathrm{g} / \mathrm{mL}) \mathrm{mL}$

Level: (TRACE/LOW/MED) TRACE

\% Moisture: not dec.

GC Column: DB-624

ID: 0.53

Soil Extract Volume:

Purge Volume: 25.0
Contract: $8 \mathrm{E}-00302$

SDG No.: 130491
Lab Sample ID: 787276D1

Lab File ID: $787276 \mathrm{D}$

Date Received: 03/06/2009

Date Analyzed: 03/10/2009

Dilution Factor: 2.0

Soil Aliquot Volume:

(uL)

(mL)

\begin{tabular}{|c|c|c|c|}
\hline CAS NO. & COMPOUND & $\begin{array}{l}\text { CONCENTRATION UNITS: } \\
(\mathrm{ug} / \mathrm{L} \text { or } \mathrm{ug} / \mathrm{kg}) \mathrm{ug} / \mathrm{L}\end{array}$ & Q \\
\hline 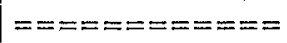 & 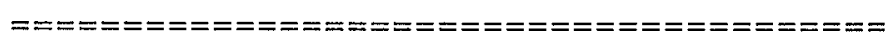 & 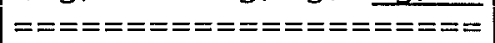 & $======= \pm$ \\
\hline $79-01-6$ & Trichloroethene & 1.0 & $\mathrm{U}$ \\
\hline $108-87-2$ & Methylcyclohexane & 1.0 & $\mathrm{U}$ \\
\hline $78-87-5$ & 1,2-Dichloropropane & 1.0 & $\mathrm{U}$ \\
\hline $75-27-4$ & Bromodichloromethane & 1.0 & $\mathrm{U}$ \\
\hline $10061-01-5$ & cis-1,3-Dichloropropene & 1.0 & $\mathrm{U}$ \\
\hline $108-10-1$ & 4-Methyl-2-pentanone & 10 & $\mathrm{U}$ \\
\hline $108-88-3$ & Toluene & 1.0 & $\mathrm{U}$ \\
\hline $10061-02-6$ & trans-1,3-Dichloropropene & 1.0 & $\mathrm{U}$ \\
\hline $79-00-5$ & 1,1,2-Trichloroethane & 1.0 & $\mathrm{U}$ \\
\hline $127-18-4$ & Tetrachloroethene & 1.0 & $\mathrm{U}$ \\
\hline $591-78-6$ & 2-Hexanone & 10 & $\mathrm{U}$ \\
\hline $124-48-1$ & Dibromochloromethane & 1.0 & $\mathrm{U}$ \\
\hline $106-93-4$ & 1,2-Dibromoethane & 1.0 & $\mathrm{U}$ \\
\hline $108-90-7$ & Chlorobenzene & 1.0 & $\mathrm{U}$ \\
\hline $100-41-4$ & Ethylbenzene & 1.0 & $\mathrm{U}$ \\
\hline $95-47-6$ & o-Xylene & 1.0 & $\mathrm{U}$ \\
\hline $179601-23-1$ & m,p-Xylene & 1.0 & $\mathrm{U}$ \\
\hline $100-42-5$ & styrene & 1.0 & $\mathrm{U}$ \\
\hline $75-25-2$ & Bromoform & 1.0 & $\mathrm{U}$ \\
\hline $98-82-8$ & Isopropylbenzene & 1.0 & $\mathrm{U}$ \\
\hline $79-34-5$ & $1,1,2,2$-Tetrachloroethane & 1.0 & $\mathrm{U}$ \\
\hline $541-73-1$ & 1,3-Dichlorobenzene & 1.0 & $\mathrm{U}$ \\
\hline $106-46-7$ & 1,4-Dichlorobenzene & 1.0 & $\mathrm{U}$ \\
\hline $95-50-1$ & 1,2-Dichlorobenzene & 1.0 & $\mathrm{U}$ \\
\hline $96-12-8$ & 1,2-Dibromo-3-chloropropane & 1.0 & $\mathrm{U}$ \\
\hline $120-82-1$ & 1,2,4-Trichlorobenzene & 1.0 & $\mathrm{U}$ \\
\hline $87-61-6$ & 1,2,3-Trichlorobenzene & 1.0 & $\mathrm{U}$ \\
\hline
\end{tabular}


Lab Name: TESTAMERICA BURLINGTON

Lab Code: STLV Case No.: BARNES

Matrix: (SOIL/SED/WATER) Water

Sample wt/vol: 25.0

$(\mathrm{g} / \mathrm{mL}) \mathrm{mL}$

Level: (TRACE/LOW/MED) TRACE

$\div$ Moisture: not dec.

GC Column: DB-624

ID : 0.53

Soil Extract Volume:

Purge Volume: 25.0
Contract: $8 E-00302$

Mod. Ref No. :
SDG No.: 130491
Lab Sample ID: 787277

Lab File ID: 787277

Date Received: 03/06/2009

Date Analyzed: 03/10/2009

Dilution Factor: 1.0

Soil Aliquot Volume:

(mL)

\begin{tabular}{|c|c|c|c|}
\hline CAS NO. & COMPOUND & $\begin{array}{l}\text { CONCENTRATION UNITS: } \\
(\mathrm{ug} / \mathrm{L} \text { or } \mathrm{ug} / \mathrm{kg}) \mathrm{ug} / \mathrm{L}\end{array}$ & Q \\
\hline$==========$ & 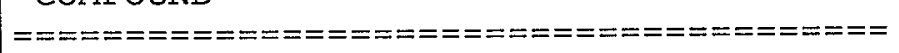 & 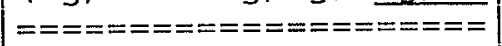 & $======3$ \\
\hline $75-71-8$ & Dichlorodifluoromethane & 0.50 & $\mathrm{U}$ \\
\hline $74-87-3$ & Chloromethane & 0.50 & $\mathrm{U}$ \\
\hline $75-01-4$ & Vinyl chloride & 0.50 & $\mathrm{U}$ \\
\hline $74-83-9$ & Bromomethane & 0.50 & $\mathrm{U}$ \\
\hline $75-00-3$ & Chloroethane & 0.50 & $\mathrm{U}$ \\
\hline $75-69-4$ & Trichlorofluoromethane & 0.50 & $\mathrm{U}$ \\
\hline $75-35-4$ & 1,1-Dichloroethene & 0.50 & $\mathrm{U}$ \\
\hline $76-13-1$ & 1,1,2-Trichloro-1,2,2-trifluoroethane & 0.50 & $\mathrm{U}$ \\
\hline $67-64-1$ & Acetone & 5.0 & $\mathrm{U}$ \\
\hline $75-15-0$ & Carbon disulfide & 0.50 & $\mathrm{U}$ \\
\hline $79-20-9$ & Methyl acetate & 0.50 & $\mathrm{U}$ \\
\hline $75-09-2$ & Methylene chloride & 0.50 & U \\
\hline $156-60-5$ & trans-1,2-Dichloroethene & 0.50 & $\mathrm{U}$ \\
\hline $1634-04-4$ & Methyl tert-butyl ether & 0.50 & $\mathrm{U}$ \\
\hline $75-34-3$ & 1,1-Dichloroethane & 0.50 & $\mathrm{U}$ \\
\hline $156-59-2$ & cis-1,2-Dichloroethene & 0.50 & $U$ \\
\hline $78-93-3$ & 2-Butanone & 5.0 & $\mathrm{U}$ \\
\hline $74-97-5$ & Bromochloromethane & 0.50 & $\mathrm{U}$ \\
\hline $67-66-3$ & Chloroform & 0.58 & \\
\hline $71-55-6$ & 1,1,1-Trichloroethane & 0.50 & $\overline{\mathrm{U}}$ \\
\hline $110-82-7$ & Cyclohexane & 0.50 & $\mathrm{U}$ \\
\hline $56-23-5$ & Carbon tetrachloride & 5.3 & \\
\hline $71-43-2$ & Benzene & 0.50 & $\overline{\mathrm{U}}$ \\
\hline $107-06-2$ & 1,2-Dichloroethane & 0.50 & $\mathrm{U}$ \\
\hline
\end{tabular}

Report 1,4-Dioxane for Low-Medium VOA analysis only 
Lab Name: TESTAMERICA BURLINGTON

Lab code: STLV Case No.: BARNES

Matrix: (SOIL/SED/WATER) Water

Sample wt/vol: 25.0

$(\mathrm{g} / \mathrm{mL}) \mathrm{mL}$

Level: (TRACE/LOW/MED) TRACE

$\%$ Moisture: not dec.

GC Column: DB-624

ID $: 0.53$

Soil Extract Volume:

Purge Volume: 25.0
Contract: $8 \mathrm{E}-00302$

Mod. Ref No.:
SDG No.: 130491
Lab Sample ID: 787277

Lab File ID: 787277

Date Received: 03/06/2009

Date Analyzed: 03/10/2009

Dilution Factor: 1.0

Soil Aliquot Volume:

(mL)

\begin{tabular}{|c|c|c|c|}
\hline $\begin{array}{l}\text { CAS NO. } \\
===========\end{array}$ & 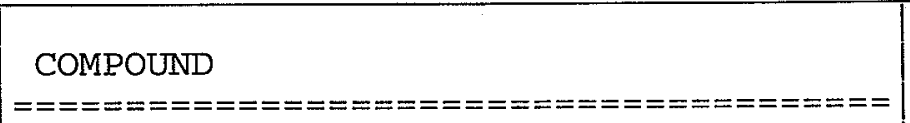 & $\begin{array}{l}\text { CONCENTRATION UNITS: } \\
(\mathrm{ug} / \mathrm{L} \text { or } \mathrm{ug} / \mathrm{kg}) \mathrm{ug} / \mathrm{L} \\
==================\end{array}$ & $=======$ \\
\hline $79-01-6$ & Trichloroethene & 0.50 & $\mathrm{U}$ \\
\hline $108-87-2$ & Methylcyclohexane & 0.50 & $\mathrm{U}$ \\
\hline $78-87-5$ & 1,2-Dichloropropane & 0.50 & $\mathrm{U}$ \\
\hline $75-27-4$ & Bromodichloromethane & 0.50 & $\mathrm{U}$ \\
\hline $10061-01-5$ & cis-1,3-Dichloropropene & 0.50 & $\mathrm{U}$ \\
\hline $108-10-1$ & 4-Methyl-2-pentanone & 5.0 & $\mathrm{U}$ \\
\hline $108-88-3$ & Toluene & 0.50 & $\mathrm{U}$ \\
\hline $10061-02-6$ & trans-1,3-Dichloropropene & 0.50 & $\mathrm{U}$ \\
\hline $79-00-5$ & 1,1,2-Trichloroethane & 0.50 & U \\
\hline $127-18-4$ & Tetrachloroethene & 0.50 & $\mathrm{U}$ \\
\hline $591-78-6$ & 2-Hexanone & 5.0 & $\mathrm{U}$ \\
\hline $124-48-1$ & Dibromochloromethane & 0.50 & $\mathrm{U}$ \\
\hline $106-93-4$ & 1,2-Dibromoethane & 0.50 & $\mathrm{U}$ \\
\hline $108-90-7$ & Chlorobenzene & 0.50 & $\mathrm{U}$ \\
\hline $100-41-4$ & Ethylbenzene & 0.50 & $\mathrm{U}$ \\
\hline $95-47-6$ & o-xylene & 0.50 & $\mathrm{U}$ \\
\hline $179601-23-1$ & $\mathrm{~m}, \mathrm{p}$-xylene & 0.50 & $\mathrm{U}$ \\
\hline $100-42-5$ & styrene & 0.50 & $\mathrm{U}$ \\
\hline $75-25-2$ & Bromoform & 0.50 & $\mathrm{U}$ \\
\hline $98-82-8$ & Isopropylbenzene & 0.50 & $\mathrm{U}$ \\
\hline $79-34-5$ & $1,1,2,2$-Tetrachloroethane & 0.50 & $\mathrm{U}$ \\
\hline $541-73-1$ & 1,3-Dichlorobenzene & 0.50 & $\mathrm{U}$ \\
\hline $106-46-7$ & 1,4-Dichlorobenzene & 0.50 & $\mathrm{U}$ \\
\hline $95-50-1$ & 1,2-Dichlorobenzene & 0.50 & $\mathrm{U}$ \\
\hline $96-12-8$ & 1,2-Dibromo-3-chloropropane & 0.50 & U \\
\hline $120-82-1$ & 1,2,4-Trichlorobenzene & 0.50 & U \\
\hline $87-61-6$ & 1,2,3-Trichlorobenzene & 0.50 & $\mathrm{U}$ \\
\hline
\end{tabular}


Lab Name: TESTAMERICA BURLINGTON

Lab Code: STLV Case No.: BARNES

Matrix: (SOIL/SED/WATER) Water

Sample wt/vol: 25.0

$(\mathrm{g} / \mathrm{mL}) \mathrm{mL}$

Level: (TRACE/LOW/MED) TRACE

\% Moisture: not dec.

GC Column: DB-624

ID $: 0.53$

Soil Extract Volume:

Purge Volume: 25.0
Contract: 8E-00302

Mod. Ref No.:
SDG No.: 130491
Lab Sample ID: 787278

Lab File ID: 787278

Date Received: 03/06/2009

Date Analyzed: 03/10/2009

Dilution Factor: 1.0

Soil Aliquot Volume:

(mL)

\begin{tabular}{|c|c|c|c|}
\hline CAS NO. & COMPOUND & $\begin{array}{l}\text { CONCENTRATION UNITS: } \\
(\mathrm{ug} / \mathrm{L} \text { or } \mathrm{ug} / \mathrm{kg}) \mathrm{ug} / \mathrm{L}\end{array}$ & $Q$ \\
\hline$==========$ & 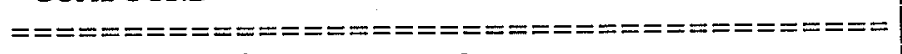 & $====================0$ & $=======$ \\
\hline $75-71-8$ & Dichlorodifluoromethane & 0.50 & $\mathrm{U}$ \\
\hline $74-87-3$ & Chloromethane & 0.50 & $\mathrm{U}$ \\
\hline $75-01-4$ & Vinyl chloride & 0.50 & $\mathrm{U}$ \\
\hline $74-83-9$ & Bromomethane & 0.50 & $\mathrm{U}$ \\
\hline $75-00-3$ & Chloroethane & 0.50 & U \\
\hline $75-69-4$ & Trichlorofluoromethane & 0.50 & $\mathrm{U}$ \\
\hline $75-35-4$ & 1,1-Dichloroethene & 0.50 & $\mathrm{U}$ \\
\hline $76-13-1$ & $1,1,2$-Trichloro-1,2,2-trifluoroethane & 0.50 & $\mathrm{U}$ \\
\hline $67-64-1$ & Acetone & 5.0 & U \\
\hline $75-15-0$ & Carbon disulfide & 0.50 & $\mathrm{U}$ \\
\hline $79-20-9$ & Methyl acetate & 0.50 & $\mathrm{U}$ \\
\hline $75-09-2$ & Methylene chloride & 0.50 & $\mathrm{U}$ \\
\hline $156-60-5$ & trans-1,2-Dichloroethene & 0.50 & $\mathrm{U}$ \\
\hline $1634-04-4$ & Methyl tert-butyl ether & 0.50 & $\mathrm{U}$ \\
\hline $75-34-3$ & $1,1^{\circ}$-Dichloroethane & 0.50 & $\mathrm{U}$ \\
\hline $156-59-2$ & cis-1,2-Dichloroethene & 0.50 & $\mathrm{U}$ \\
\hline $78-93-3$ & 2-Butanone & 5.0 & $\mathrm{U}$ \\
\hline $74-97-5$ & Bromochloromethane & 0.50 & U \\
\hline $67-66-3$ & Chloroform & 0.50 & $\mathrm{U}$ \\
\hline $71-55-6$ & $1,1,1$-Trichloroethane & 0.50 & $\mathrm{U}$ \\
\hline $110-82-7$ & Cyclohexane & 0.50 & $\mathrm{U}$ \\
\hline $56-23-5$ & Carbon tetrachloride & 0.62 & \\
\hline $71-43-2$ & Benzene & 0.50 & $\overline{\mathrm{U}}$ \\
\hline $107-06-2$ & 1,2-Dichloroethane & 0.50 & $\mathrm{U}$ \\
\hline
\end{tabular}

Report 1,4-Dioxane for Low-Medium VOA analysis only 
Lab Name: TESTAMERICA BURIINGTON

Lab Code: STLV Case No.: BARNES

Matrix: (SOIL/SED/WATER) water

Sample wt/vol: $25.0 \quad(\mathrm{~g} / \mathrm{mL}) \mathrm{mL}$

Leve1: (TRACE/LOW/MED) TRACE

\% Moisture: not dec.

GC Column: DB-624

Soil Extract Volume:

ID : 0.53

(mm)

(uL)

Contract: 8E-00302

Mod. Ref No.:
SDG No.: 130491
Purge Volume: 25.0
Lab Sample ID: 787278

Lab File ID: 787278

Date Received: 03/06/2009

Date Analyzed: 03/10/2009

Dilution Factor: 1.0

Soil Aliquot Volume:

(uL)

\begin{tabular}{|c|c|c|c|}
\hline $\begin{array}{l}\text { CAS NO. } \\
========== \\
79-01-6 \\
108-87-2 \\
78-87-5 \\
75-27-4 \\
10061-01-5 \\
108-10-1 \\
108-88-3 \\
10061-02-6 \\
79-00-5 \\
127-18-4 \\
591-78-6 \\
124-48-1 \\
106-93-4 \\
108-90-7 \\
100-41-4 \\
95-47-6 \\
179601-23-1 \\
100-42-5 \\
75-25-2 \\
98-82-8 \\
79-34-5 \\
541-73-1 \\
106-46-7 \\
95-50-1 \\
96-12-8 \\
120-82-1 \\
87-61-6\end{array}$ & $\begin{array}{l}\text { COMPOUND } \\
\text { Trichloroethene } \\
\text { Methylcyclohexane } \\
\text { 1,2-Dichloropropane } \\
\text { Bromodichloromethane } \\
\text { cis-1,3-Dichloropropene } \\
\text { 4-Methyl-2-pentanone } \\
\text { Toluene } \\
\text { trans-1,3-Dichloropropene } \\
\text { 1,1,2-Trichloroethane } \\
\text { Tetrachloroethene } \\
2-\text { Hexanone } \\
\text { Dibromochloromethane } \\
\text { 1,2-Dibromoethane } \\
\text { Chlorobenzene } \\
\text { Ethylbenzene } \\
\text {-Xylene } \\
\text { m, p-Xylene } \\
\text { Styrene } \\
\text { Bromoform } \\
\text { Isopropylbenzene } \\
1,1,2,2-\text { Tetrachloroethane } \\
1,3-\text { Dichlorobenzene } \\
1,4-\text { Dichlorobenzene } \\
1,2-\text { Dichlorobenzene } \\
1,2-\text { Dibromo-3-chloropropane } \\
1,2,4-\text { Trichlorobenzene } \\
1,2,3-\text { Trichlorobenzene }\end{array}$ & 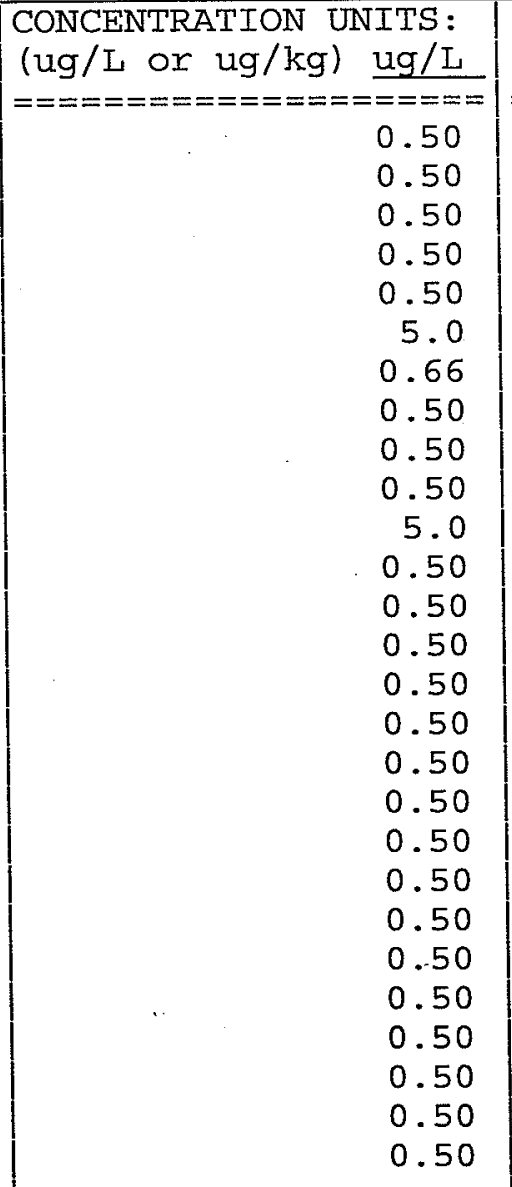 & $=\begin{array}{c}Q \\
====== \\
U \\
U \\
U \\
U \\
U \\
U\end{array}$ \\
\hline
\end{tabular}


$1 A$ - FORM I VOA-1

VOLATILE ORGANICS ANALYSIS DATA SHEET
EPA SAMPLE NO.

BAQCTB28637
Lab Name: TESTAMERICA BURLINGTON

Lab Code: STLV Case No.: BARNES

Matrix: (SOIL/SED/WATER) water

Sample wt/vol: $25.0(\mathrm{~g} / \mathrm{mL}) \mathrm{mL}$

Level: (TRACE/LOW/MED) TRACE

\% Moisture: not dec.

GC Column: DB-624

Soil Extract Volume:

ID : 0.53

Purge Volume: 25.0
Contract: $8 \mathrm{E}-00302$

Mod. Ref No.:

SDG No. : 130491
Lab Sample ID: 787279

Lab File ID: 787279

Date Received: 03/06/2009

Date Analyzed: 03/10/2009

Dilution Factor: 1.0

Soil Aliquot Volume:

(uL)

(mL)

\begin{tabular}{|c|c|c|c|}
\hline $\begin{array}{c}\text { CAS NO. } \\
========= \\
75-71-8 \\
74-87-3 \\
75-01-4 \\
74-83-9 \\
75-00-3 \\
75-69-4 \\
75-35-4 \\
76-13-1 \\
67-64-1 \\
75-15-0 \\
79-20-9 \\
75-09-2 \\
156-60-5 \\
1634-04-4 \\
75-34-3 \\
156-59-2 \\
78-93-3 \\
74-97-5 \\
67-66-3 \\
71-55-6 \\
110-82-7 \\
56-23-5 \\
71-43-2 \\
107-06-2\end{array}$ & $\begin{array}{l}\text { COMPOUND } \\
\text { Dichlorodifluoromethane } \\
\text { Chloromethane } \\
\text { Vinyl chloride } \\
\text { Bromomethane } \\
\text { Chloroethane } \\
\text { Trichlorofluoromethane } \\
1,1-D i \text { chloroethene } \\
1,1,2-\text { Trichloro-1, } 2,2-t r i f l u o r o e t h a n e \\
\text { Acetone } \\
\text { Carbon disulfide } \\
\text { Methyl acetate } \\
\text { Methylene chloride } \\
\text { trans-1,2-Dichloroethene } \\
\text { Methyl tert-butyl ether } \\
1,1-D i c h l o r o e t h a n e \\
\text { cis-1,2-Dichloroethene } \\
2-\text { Butanone } \\
\text { Bromochloromethane } \\
\text { Chloroform } \\
1,1,1-\text { Trichloroethane } \\
\text { Cyclohexane } \\
\text { Carbon tetrachloride } \\
\text { Benzene } \\
1,2-D i c h l o r o e t h a n e\end{array}$ & 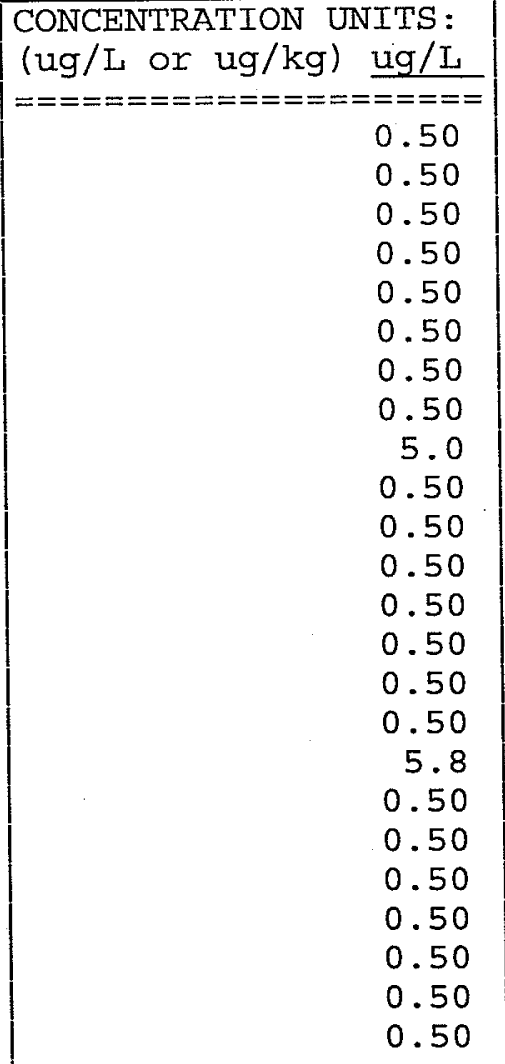 & 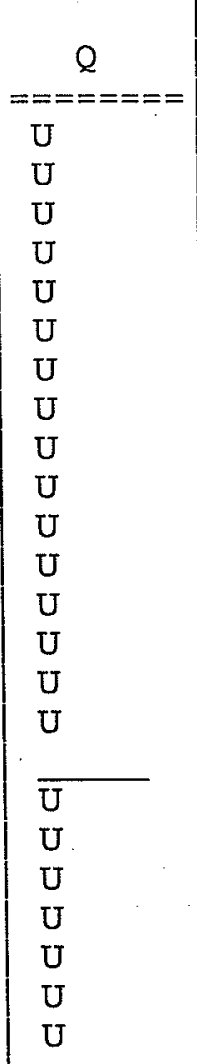 \\
\hline
\end{tabular}

Report 1,4-Dioxane for Low-Medium VOA analysis only 
Lab Name: TESTAMERICA BURLINGTON

Lab Code: STLV Case No.: BARNES

Matrix: (SOIL/SED/WATER) Water

Sample wt/vol: 25.0

$(\mathrm{g} / \mathrm{mL}) \mathrm{mL}$

Level: (TRACE/LOW/MED) TRACE

\% Moisture: not dec.

GC Column: DB-624

ID: 0.53

(mm)

(uL)

Contract: $8 E-00302$

Mod. Ref No.:
SDG No.: 130491
Soil Extract Volume:

Purge Volume: 25.0
Lab Sample ID: 787279

Lab File ID: 787279

Date Received: 03/06/2009

Date Analyzed: 03/10/2009

Dilution Factor: 1.0

Soil Aliquot Volume:

(uL)

\begin{tabular}{|c|c|c|c|}
\hline CAS NO. & COMPOUND & $\begin{array}{l}\text { CONCENTRATION UNITS: } \\
(\mathrm{ug} / \mathrm{L} \text { or } \mathrm{ug} / \mathrm{kg}) \mathrm{ug} / \mathrm{L}\end{array}$ & Q \\
\hline$==========$ & 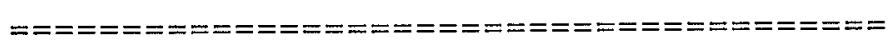 & $=============== \pm====$ & $========$ \\
\hline $79-01-6$ & Trichloroethene & 0.50 & $\mathrm{U}$ \\
\hline $108-87-2$ & Methylcyclohexane & 0.50 & $\mathrm{U}$ \\
\hline $78-87-5$ & 1,2-Dichloropropane & 0.50 & $\mathrm{U}$ \\
\hline $75-27-4$ & Bromodichloromethane & 0.50 & $\mathrm{U}$ \\
\hline $10061-01-5$ & cis-1,3-Dichloropropene & 0.50 & $\mathrm{U}$ \\
\hline $108-10-1$ & 4-Methyl-2-pentanone & 5.0 & $\mathrm{U}$ \\
\hline $108-88-3$ & Toluene & 0.50 & $\mathrm{U}$ \\
\hline $10061-02-6$ & trans-1,3-Dichloropropene & 0.50 & $\mathrm{U}$ \\
\hline $79-00-5$ & 1,1,2-Trichloroethane & 0.50 & $\mathrm{U}$ \\
\hline $127-18-4$ & Tetrachloroethene & 0.50 & $\mathrm{U}$ \\
\hline $591-78-6$ & 2 -Hexanone & 5.0 & $\mathrm{U}$ \\
\hline $124-48-1$ & Dibromochloromethane & 0.50 & $\mathrm{U}$ \\
\hline $106-93-4$ & 1,2-Dibromoethane & 0.50 & $\mathrm{U}$ \\
\hline $108-90-7$ & Chlorobenzene & 0.50 & $\mathrm{U}$ \\
\hline $100-41-4$ & Ethylbenzene & 0.50 & U \\
\hline $95-47-6$ & o-Xylene & 0.50 & $\mathrm{U}$ \\
\hline $179601-23-1$ & $\mathrm{~m}, \mathrm{p}$-Xylene & 0.50 & $\mathrm{U}$ \\
\hline $100-42-5$ & styrene & 0.50 & $\mathrm{U}$ \\
\hline $75-25-2$ & Bromoform & 0.50 & U \\
\hline $98-82-8$ & Isopropylbenzene & 0.50 & $\mathrm{U}$ \\
\hline $79-34-5$ & $1,1,2,2$-Tetrachloroethane & 0.50 & $\mathrm{U}$ \\
\hline $541-73-1$ & 1,3-Dichlorobenzene & 0.50 & $\mathrm{U}$ \\
\hline $106-46-7$ & 1,4-Dichlorobenzene & 0.50 & $\mathrm{U}$ \\
\hline $95-50-1$ & 1,2-Dichlorobenzene & 0.50 & $\mathrm{U}$ \\
\hline $96-12-8$ & 1,2-Dibromo-3-chloropropane & 0.50 & $\mathrm{U}$ \\
\hline $120-82-1$ & $1,2,4$-Trichlorobenzene & 0.50 & $\mathrm{U}$ \\
\hline $87-61-6$ & $1,2,3$-Trichlorobenzene & 0.50 & $\mathrm{U}$ \\
\hline
\end{tabular}


Lab Name: TESTAMERICA BURLINGTON

Lab Code: STLV Case No.: BARNES

Matrix: (SOIL/SED/WATER) Water

Sample wt/vol: 25.0

$(\mathrm{g} / \mathrm{mL}) \mathrm{mL}$

Level: (TRACE/LOW/MED) TRACE

\% Moisture: not dec.

GC Column: DB-624

Soil Extract Volume:

ID : 0.53

Purge Volume: 25.0
Contract: $8 \mathrm{E}-00302$

Mod. Ref No.:
SDG NO.: 130491
Lab Sample ID: 787280

Lab File ID: 787280

Date Received:

Date Analyzed: 03/10/2009

Dilution Factor: 1.0

Soil Aliquot Volume:

(uL)

(mL)

\begin{tabular}{|c|c|c|c|}
\hline CAS NO. & COMPOUND & $\begin{array}{l}\text { CONCENTRATION UNITS: } \\
(\mathrm{ug} / \mathrm{L} \text { or } \mathrm{ug} / \mathrm{kg}) \mathrm{ug} / \mathrm{L}\end{array}$ & $Q$ \\
\hline$==========$ & 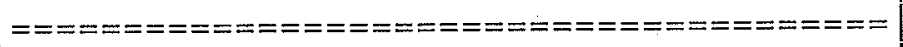 & 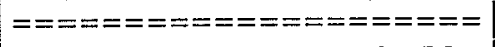 & $=======$ \\
\hline $75-71-8$ & Dichlorodifluoromethane & 0.50 & $\mathrm{U}$ \\
\hline $74-87-3$ & Chloromethane & 0.50 & $\mathrm{U}$ \\
\hline $75-01-4$ & Vinyl chloride & 0.50 & $\mathrm{U}$ \\
\hline $74-83-9$ & Bromomethane & 0.50 & U \\
\hline $75-00-3$ & Chloroethane & 0.50 & U \\
\hline $75-69-4$ & Trichlorofluoromethane & 0.50 & $\mathrm{U}$ \\
\hline $75-35-4$ & 1,1 -Dichloroethene & 0.50 & $\mathrm{U}$ \\
\hline $76-13-1$ & 1, 1,2-Trichloro-1,2,2-trifluoroethane & 0.50 & $\mathrm{U}$ \\
\hline $67-64-1$ & Acetone & 5.0 & $\mathrm{U}$ \\
\hline $75-15-0$ & Carbon disulfide & 0.50 & U \\
\hline $79-20-9$ & Methyl acetate & 0.50 & U \\
\hline $75-09-2$ & Methylene chloride & 0.50 & $\mathrm{U}$ \\
\hline $156-60-5$ & trans-1,2-Dichloroethene & 0.50 & $\mathrm{U}$ \\
\hline $1634-04-4$ & Methyl tert-butyl ether & 0.50 & $\mathrm{U}$ \\
\hline $75-34-3$ & 1,1-Dichloroethane & 0.50 & U \\
\hline $156-59-2$ & cis-1,2-Dichloroethene & 0.50 & U \\
\hline $78-93-3$ & 2-Butanone & 5.0 & $U$ \\
\hline $74-97-5$ & Bromochloromethane & 0.50 & $\mathrm{U}$ \\
\hline $67-66-3$ & Chloroform & 0.50 & $\mathrm{U}$ \\
\hline $71-55-6$ & $1,1,1$-Trichloroethane & 0.50 & $\mathrm{U}$ \\
\hline $110-82-7$ & Cyclohexane & 0.50 & $\mathrm{U}$ \\
\hline $56-23-5$ & Carbon tetrachloride & 0.50 & $\mathrm{U}$ \\
\hline $71-43-2$ & Benzene & 0.50 & $\mathrm{U}$ \\
\hline $107-06-2$ & 1,2-Dichloroethane & 0.50 & $\mathrm{U}$ \\
\hline
\end{tabular}

Report 1,4-Dioxane for Low-Medium VOA analysis only 
Lab Name: TESTAMERICA BURLINGTON

Lab Code: STLV

Case No.: BARNES

Matrix: (SOIL/SED/WATER) Water

Sample wt/vol: 25.0

$(\mathrm{g} / \mathrm{mL}) \mathrm{mL}$

Level: (TRACE/LOW/MED) TRACE

\% Moisture: not dec.

GC Column: DB-624

Soil Extract Volume:

ID $: 0.53$

Contract: $8 E-00302$

Mod. Ref No.:
SDG No.: 130491 $(\mathrm{mm})$

(UL)

Lab Sample ID: 787280

Lab File ID: 787280

Date Received:

Date Analyzed: 03/10/2009

Dilution Factor: 1.0

Soil Aliquot Volume:

(uL)

(mL)

\begin{tabular}{|c|c|c|c|}
\hline CAS NO. & COMPOUND & \begin{tabular}{|l|} 
CONCENTRATION UNITS: \\
$(\mathrm{ug} / \mathrm{L}$ or $\mathrm{ug} / \mathrm{kg}) \mathrm{ug} / \mathrm{L}$
\end{tabular} & $Q$ \\
\hline$==========$ & 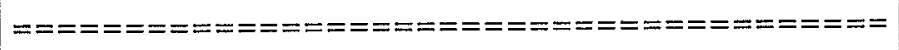 & $==== \pm====0== \pm==0===0=$ & $=======$ \\
\hline $79-01-6$ & Trichloroethene & 0.50 & $\mathrm{U}$ \\
\hline $108-87-2$ & Methylcyclohexane & 0.50 & $\mathrm{U}$ \\
\hline $78-87-5$ & 1,2-Dichloropropane & 0.50 & U \\
\hline $75-27-4$ & Bromodichloromethane & 0.50 & $\mathrm{U}$ \\
\hline $10061-01-5$ & Cis-1,3-Dichloropropene & 0.50 & $\mathrm{U}$ \\
\hline $108-10-1$ & 4-Methyl-2-pentanone & 5.0 & $\mathrm{U}$ \\
\hline $108-88-3$ & Toluene & 0.50 & U \\
\hline $10061-02-6$ & trans-1,3-Dichloropropene & 0.50 & $\mathrm{U}$ \\
\hline $79-00-5$ & $1,1,2$-Trichloroethane & 0.50 & $\mathrm{U}$ \\
\hline $127-18-4$ & Tetrachloroethene & 0.50 & $\mathrm{U}$ \\
\hline $591-78-6$ & 2-Hexanone & 5.0 & U \\
\hline $124-48-1$ & Dibromochloromethane & 0.50 & U \\
\hline $106-93-4$ & 1,2-Dibromoethane & 0.50 & $\mathrm{U}$ \\
\hline $108-90-7$ & Chlorobenzene & 0.50 & $\mathrm{U}$ \\
\hline $100-41-4$ & Ethylbenzene & 0.50 & $\mathrm{U}$ \\
\hline $95-47-6$ & o-Xylene & 0.50 & $\mathrm{U}$ \\
\hline $179601-23-1$ & $\mathrm{~m}, \mathrm{p}-\mathrm{xy}$ lene & 0.50 & $\mathrm{U}$ \\
\hline $100-42-5$ & Styrene & 0.50 & $\mathrm{U}$ \\
\hline $75-25-2$ & Bromoform & 0.50 & $\mathrm{U}$ \\
\hline $98-82-8$ & Isopropylbenzene & 0.50 & $\mathrm{U}$ \\
\hline $79-34-5$ & $1,1,2,2$-Tetrachloroethane & 0.50 & $\mathrm{U}$ \\
\hline $541-73-1$ & 1,3-Dichlorobenzene & 0.50 & $\mathrm{U}$ \\
\hline $106-46-7$ & 1,4-Dichlorobenzene & 0.50 & $\mathrm{U}$ \\
\hline $95-50-1$ & 1,2-Dichlorobenzene & 0.50 & U \\
\hline $96-12-8$ & 1,2-Dibromo-3-chloropropane & 0.50 & $\mathrm{U}$ \\
\hline $120-82-1$ & $1,2,4$-Trichlorobenzene & 0.50 & $\mathrm{U}$ \\
\hline $87-61-6$ & 1,2,3-Trichlorobenzene & 0.50 & $\mathrm{U}$ \\
\hline
\end{tabular}




\section{TestAmerica}

THE LEADERIN ENVIRONMENTALTESTING

TestAmerica Laboratories, Inc.

June 29, 2009

Mr. Clyde Dennis

Argonne National Laboratory

9700 S. Cass Avenue

Bldg. 203, Office B149

Argonne, IL 60439

Re: Laboratory Project No. 21005

Case: BARNES: SDG: 132283

Dear Mr. Dennis:

Enclosed are analytical results for samples that were received by TestAmerica Burlington on June $19^{\text {th }}, 2009$. Laboratory identification numbers were assigned, and designated as follows:

$\begin{array}{llll}\text { Lab ID } & \begin{array}{l}\text { Client } \\ \text { Sample ID }\end{array} & \begin{array}{l}\text { Sample } \\ \text { Date }\end{array} & \begin{array}{l}\text { Sample } \\ \text { Matrix }\end{array} \\ & \text { Received: 06/19/09 } & & \\ & & & \\ 798781 & \text { BAMW1D-W-28639 } & 132283 & \\ 798782 & \text { BAMW15D-W-28662 } & 06 / 17 / 09 & \text { WATER } \\ 798783 & \text { BAMW2D-W-28640 } & 06 / 17 / 09 & \text { WATER } \\ 798784 & \text { BAPWS2-W-28667 } & 06 / 18 / 09 & \text { WATER } \\ 798785 & \text { BAQCTB-W-28674 } & 06 / 18 / 09 & \text { WATER } \\ 798786 & \text { BAMW6S-W-28644 } & 06 / 18 / 09 & \text { WATER } \\ 798787 & \text { VHBLK01 } & 06 / 19 / 09 & \text { WATER } \\ & & & \end{array}$

Documentation of the condition of the samples at the time of their receipt and any exception to the laboratory's Sample Acceptance Policy is documented in the Sample Handling section of this submittal. The samples, as received, were not acid preserved. On that basis, the laboratory did provide for the analytical work to be performed within seven days of sample collection.

In order to accommodate field length limitations in processing the data summary forms, the laboratory did, in certain instances, abbreviate the sample identifier. The electronically formatted data provides for the full sample identifier. 


\section{TestAmerica}

THELEADER IN ENVIRONMENTAL TESTING

\section{SOM01.2 Volatile Organics (Trace Level Water)}

A storage blank was prepared for volatile organics analysis, and stored in association with the storage of the samples. That storage blank, identified as VHBLK01, was carried through the holding period with the samples, and analyzed.

Each of the analyses associated with the sample set exhibited an acceptable internal standard performance. There was an acceptable recovery of each deuterated monitoring compound (DMC) in the analysis the method blank associated with the analytical work, and in the analysis of the storage blank associated with the sample set. The analysis of the samples in this sample set did meet the technical acceptance criteria specific to DMC recoveries, although not all DMC recoveries were within the control range in each analysis. The technical acceptance criteria does provide for the recovery of up to three DMCs to fall outside of the control range in the analysis of field samples. The derived recovery of 2-hexanone- $d_{5}$ was elevated in the analysis of samples BAMW1D-W-28639, BAMW15D-W-28662, BAMW2D-W-28640, BAPWS2-W28667, and BAMW6S-W-28644. Matrix spike and matrix spike duplicate analyses were not performed on the samples in this sample set. The analysis of the method blank associated with the analytical work was free of contamination, as was the analysis of the storage blank associated with the sample set. Present in the method blank, instrument blank, and storage blank analyses was a non-target constituent that represented a compound that is related to the DMC formulation. The fact that the presence of this compound is not within the laboratory's control is at issue. The derived results for that compound have been qualified with an " $X$ " qualifier to reflect the source of the contamination.

The responses for each target analyte met the relative standard deviation criterion in the initial calibration. The samples in this sample set were analyzed in an analytical sequence that included the initial calibration. The response for each target analyte met the 50.0 percent difference criterion in the closing calibration check acquisition.

The primary quantitation mass for methylcyclohexane that is specified in the Statement of Work is mass 83 . The laboratory did identify a contribution to mass 83 from 1,2-dichloropropane- $d_{6}$, one of the deuterated monitoring compounds (DMCs). The laboratory did change the primary quantitation mass assignment to mass 55 for the quantification of methylcyclohexane.

Manual integration was employed in deriving certain of the analytical results. The values that have been derived from manual integration are qualified on the quantitation reports. Extracted ion current profiles for each manual integration are included in the data package, and further documented in the Sample Preparation section of this submittal.

Any reference within this report to Severn Trent Laboratories, Inc. or STL, should be understood to refer to TestAmerica Laboratories, Inc. (formerly known as Severn Trent Laboratories, Inc.) The analytical results associated with the samples presented in this test report were generated under a quality system that adheres to requirements specified in the NELAC standard. Release of the data in this test report and any associated electronic deliverables is authorized by the Laboratory Director's designee as verified by the following signature. 


\section{TestAmerica}

THE LEADER IN ENVIRONMENTAL TESTING

If there are any questions regarding this submittal, please contact me at 802 660-1990.

Sincerely,

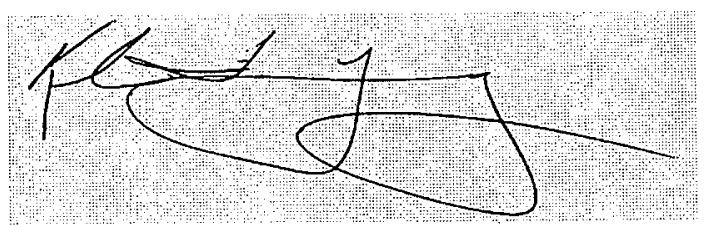

Kirk F. Young

Project Manager

KFY/hsf

Enclosure 


\section{TestAmerica Burlington Data Qualifier Definitions}

\section{Organic}

$\mathrm{U}$ : Compound analyzed but not detected at a concentration above the reporting limit.

J: Estimated value.

$\mathrm{N}$ : Indicates presumptive evidence of a compound. This flag is used only for tentatively identified compounds (TICs) where the identification of a compound is based on a mass spectral library search.

$\mathrm{P}: \quad$ SW-846: The relative percent difference for detected concentrations between two GC columns is greater than $40 \%$. Unless otherwise specified the higher of the two values is reported on the Form 1 .

CLP SOW: Greater than 25\% difference for detected concentrations between two GC columns. Unless otherwise specified the lower of the two values is reported on the Form I.

C: Pesticide result whose identification has been confirmed by GC/MS.

B: - Analyte is found in the sample and the associated method blank. The flag is used for tentatively identified compounds as well as positively identified compounds.

E: Compounds whose concentrations exceed the upper limit of the calibration range of the instrument for that specific analysis.

D: Concentrations identified from analysis of the sample at a secondary dilution.

A: Tentatively identified compound is a suspected aldol condensation product.

$X, Y, Z$ : Laboratory defined flags that may be used alone or combined, as needed. If used, the description of the flag is defined in the project narrative.

\section{Inorganic/Metals}

E: $\quad$ Reported value is estimated due to the presence of interference.

$\mathrm{N}: \quad$ Matrix spike sample recovery is not within control limits.

* Duplicate sample analysis is not within control limits.

B: The result reported is less than the reporting limit but greater than the instrument detection limit.

U: Analyte was analyzed for but not detected above the reporting limit.

Method Codes:

P ICP-AES

MS ICP-MS

CV Cold Vapor AA

AS Semi-Automated Spectrophotometric 


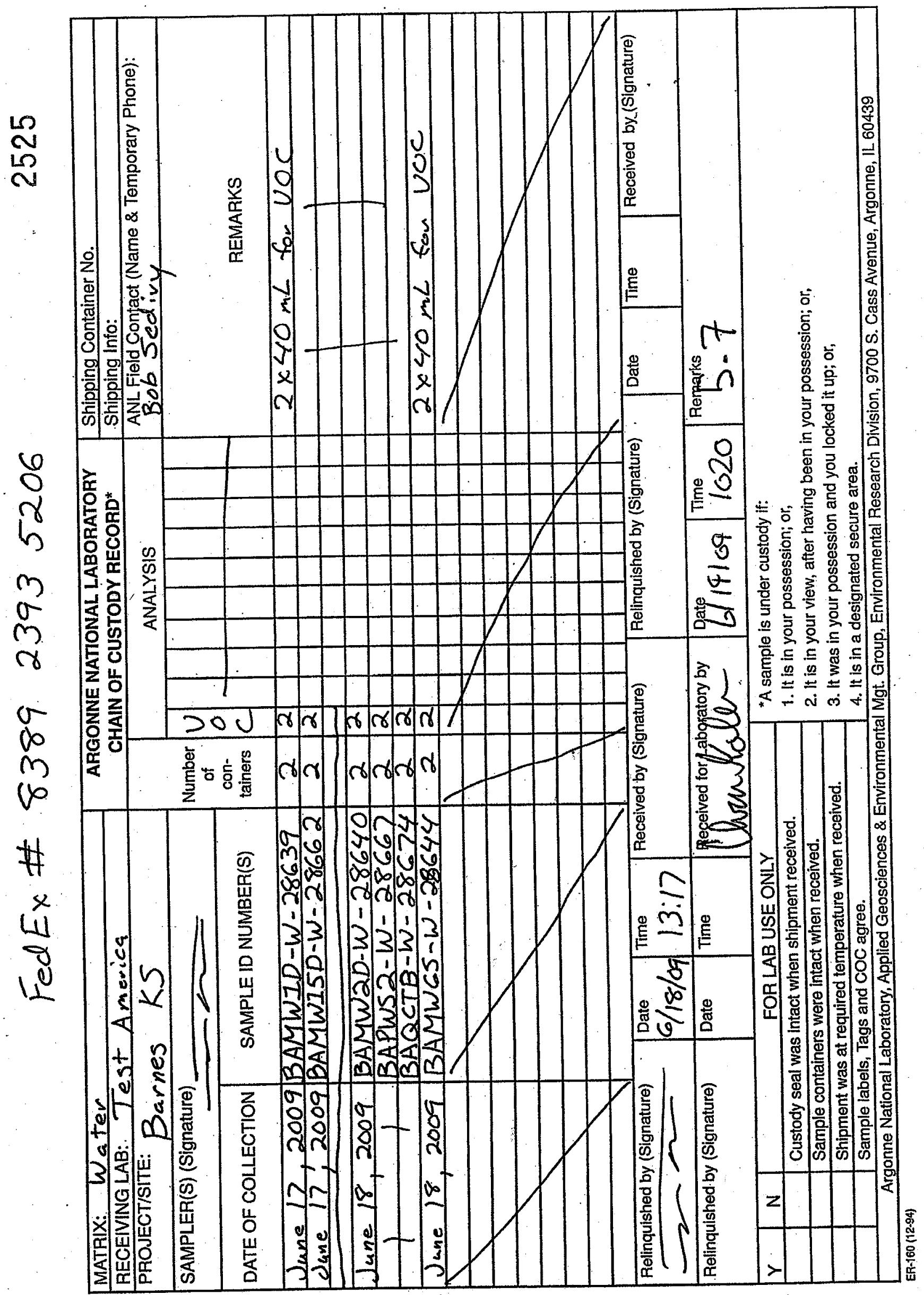




\section{TestAmerica}

THE LEADER IN ENYIRONMENTAL TESTING

\section{Sample Data Summary - SOM01.2 Volatiles - Trace}


$1 A$ - FORM I VOA-1

VOLATILE ORGANICS ANALYSIS DATA SHEET

EPA SAMPLE NO.

BAMW1DW2 8639

Lab Name: TESTAMERICA BURLINGTON

Lab Code: STLV Case No.: BARNES

Matrix: (SOIL/SED/WATER) water

Sample wt/vol: $25.0 \quad(\mathrm{~g} / \mathrm{mL}) \mathrm{mL}$

Level: (TRACE/LOW/MED) TRACE

\% Moisture: not dec.

GC Column: DB-624

Soil Extract Volume:

ID $: 0.53 \quad(\mathrm{~mm})$

Contract : 8E-00302

Mod. Ref No.:

Lab Sample ID: 798781

Lab File ID: 798781

Dilution Factor: 1.0

(uI) Soil Aliquot Volume:

SDG NO.: 132283

Date Received: 06/19/2009

Date Analyzed: 06/24/2009

(uL)

Purge Volume: 25.0

$(\mathrm{mL})$

\begin{tabular}{|c|c|c|c|}
\hline $\begin{array}{c}\text { CAS NO. } \\
========== \\
75-71-8 \\
74-87-3 \\
75-01-4 \\
74-83-9 \\
75-00-3 \\
75-69-4 \\
75-35-4 \\
76-13-1 \\
67-64-1 \\
75-15-0 \\
79-20-9 \\
75-09-2 \\
156-60-5 \\
1634-04-4 \\
75-34-3 \\
156-59-2 \\
78-93-3 \\
74-97-5 \\
67-66-3 \\
71-55-6 \\
110-82-7 \\
56-23-5 \\
71-43-2 \\
107-06-2\end{array}$ & $\begin{array}{l}\text { COMPOUND } \\
=========================== \\
\text { Dichlorodifluoromethane } \\
\text { Chloromethane } \\
\text { Vinyl chloride } \\
\text { Bromomethane } \\
\text { Chloroethane } \\
\text { Trichlorofluoromethane } \\
1,1-\text { Dichloroethene } \\
1,1,2-\text { Trichloro-1,2,2-trifluoroethane } \\
\text { Acetone } \\
\text { Carbon disulfide } \\
\text { Methyl acetate } \\
\text { Methylene chloride } \\
\text { trans-1, } 2 \text {-Dichloroethene } \\
\text { Methyl tert-butyl ether } \\
1,1-D i c h l o r o e t h a n e \\
\text { cis-1,2-Dichloroethene } \\
2-\text { Butanone } \\
\text { Bromochloromethane } \\
\text { Chloroform } \\
1,1,1-T r i c h l o r o e t h a n e \\
\text { Cyclohexane } \\
\text { Carbon tetrachloride } \\
\text { Benzene } \\
1,2-D i c h l o r o e t h a n e \\
\text { 1, }\end{array}$ & 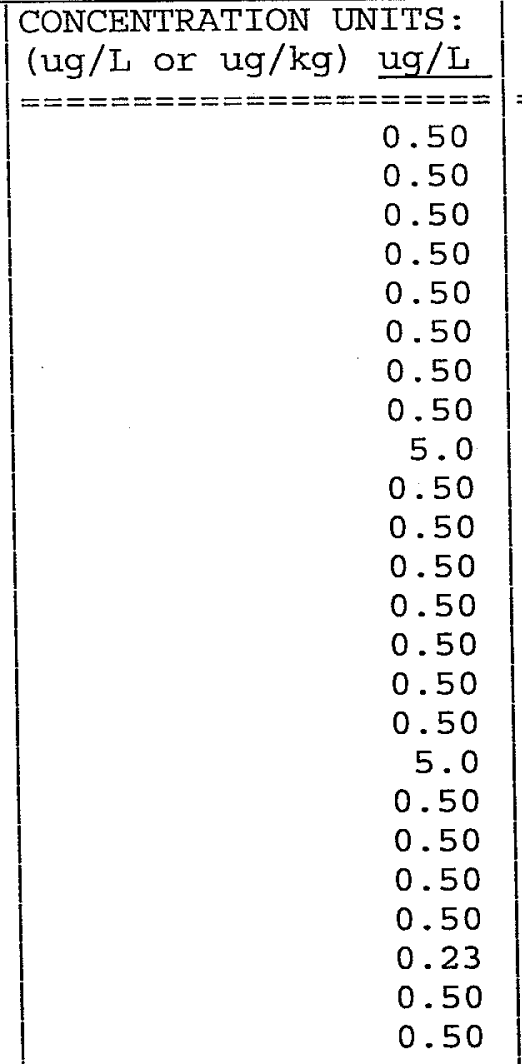 & $\begin{array}{l}========= \\
U \\
U \\
U \\
U \\
U \\
U \\
U \\
U \\
U \\
U \\
U \\
U \\
U \\
U \\
U \\
U \\
U \\
U \\
U \\
U \\
U \\
J \\
U \\
U\end{array}$ \\
\hline
\end{tabular}

Report 1,4-Dioxane for Low-Medium VOA analysis only 
$1 B$ - FORM I VOA-2

VOLATILE ORGANICS ANALYSIS DATA SHEET

Lab Name: TESTAMERICA BURLINGTON

Lab Code: STLV Case No.: BARNES

Matrix: (SOIL/SED/WATER) water

Sample wt/vol: $25.0 \quad(\mathrm{~g} / \mathrm{mL}) \mathrm{mL}$

Level : (TRACE/LOW/MED) TRACE

\% Moisture: not dec.

GC Column: DB-624

ID : 0.53

Soil Extract Volume:

Purge Volume: 25.0
Contract: 8E-00302

Mod. Ref No.:
SDG No.: 132283
Lab Sample ID: 798781

Lab File ID: 798781

Date Received: 06/19/2009

Date Analyzed: 06/24/2009

Dilution Factor: 1.0

(uL) Soil Aliquot Volume:

(uL)

(mL)

\begin{tabular}{|c|c|c|c|}
\hline CAS NO. & COMPOUND & $\begin{array}{l}\text { CONCENTRATION UNITS: } \\
(\mathrm{ug} / \mathrm{L} \text { or } \mathrm{ug} / \mathrm{kg}) \mathrm{ug} / \mathrm{L}\end{array}$ & Q \\
\hline$====== \pm====1$ & 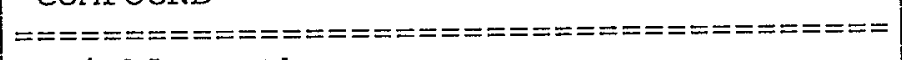 & $======= \pm==== \pm===\equiv====1$ & $========$ \\
\hline $79-01-6$ & Trichloroethene & 0.50 & $\mathrm{U}$ \\
\hline $108-87-2$ & Methylcyclohexane & 0.50 & $\mathrm{U}$ \\
\hline $78-87-5$ & 1,2-Dichloropropane & 0.50 & $\mathrm{U}$ \\
\hline $75-27-4$ & Bromodichloromethane & 0.50 & $\mathrm{U}$ \\
\hline $10061-01-5$ & cis-1,3-Dichloropropene & 0.50 & $\mathrm{U}$ \\
\hline $108-10-1$ & 4-Methy 1 -2-pentanone & 5.0 & $\mathrm{U}$ \\
\hline $108-88-3$ & Toluene & 0.50 & $\mathrm{U}$ \\
\hline $10061-02-6$ & trans-1,3-Dichloropropene & 0.50 & $\mathrm{U}$ \\
\hline $79-00-5$ & $1,1,2$-Txichloroethane & 0.50 & $\mathrm{U}$ \\
\hline $127-18-4$ & Tetrachloroethene & 0.50 & $\mathrm{U}$ \\
\hline $591-78-6$ & 2 -Hexanone & 5.0 & $\mathrm{U}$ \\
\hline $124-48-1$ & Dibromochloromethane & 0.50 & $\mathrm{U}$ \\
\hline $106-93-4$ & 1,2-Dibromoethane & 0.50 & $\mathrm{U}$ \\
\hline $108-90-7$ & Chlorobenzene & 0.50 & U \\
\hline $100-41-4$ & Ethylbenzene & 0.50 & U \\
\hline $95-47-6$ & o-XYlene & 0.50 & $\mathrm{U}$ \\
\hline $179601-23-1$ & $\mathrm{~m}, \mathrm{p}$-Xylene & 0.50 & $\mathrm{U}$ \\
\hline $100-42-5$ & Styrene & 0.50 & $\mathrm{U}$ \\
\hline $75-25-2$ & Bromoform & 0.50 & U \\
\hline $98-82-8$ & Isopropylbenzene & 0.50 & $\mathrm{U}$ \\
\hline $79-34-5$ & $1,1,2,2$-Tetrachloroethane & 0.50 & $\mathrm{U}$ \\
\hline $541-73-1$ & 1,3-Dichlorobenzene & 0.50 & $\mathrm{U}$ \\
\hline $106-46-7$ & 1,4-Dichlorobenzene & 0.50 & $\mathrm{U}$ \\
\hline $95-50-1$ & 1,2-Dichlorobenzene & 0.50 & $\mathrm{U}$ \\
\hline $96-12-8$ & 1,2-Dibromo-3-chloropropane & 0.50 & $\mathrm{U}$ \\
\hline $120-82-1$ & $1,2,4$-Trichlorobenzene & 0.50 & $\mathrm{U}$ \\
\hline $87-61-6$ & 1,2,3-Trichlorobenzene & 0.50 & U \\
\hline
\end{tabular}


IA - FORM I VOA-1

VOLATILE ORGANICS ANALYSIS DATA SHEET
EPA SAMPLE NO.

BAMW15D28662
Lab Name: TESTAMERICA BURLINGTON

Lab Code: STLV Case No.: BARNES

Matrix: (SOIL/SED/WATER) Water

Sample wt/vol: $25.0 \quad(\mathrm{~g} / \mathrm{mL}) \mathrm{mL}$

Leve1: (TRACE/LOW/MED) TRACE

$\%$ Moisture: not dec.

GC Column: DB-624

ID : 0.53

Soil Extract Volume:

Purge Volume: 25.0
Contract : 8E-00302

Mod. Ref No.:
Lab Sample ID: 798782

Lab File ID: 798782

Date Received: 06/19/2009

Date Analyzed: 06/24/2009

Dilution Factor: 1.0

Soil Aliquot Volume:

(uL)

(mL)

\begin{tabular}{|c|c|c|c|}
\hline CAS NO. & COMPOUND & $\begin{array}{l}\text { CONCENTRATION UNITS: } \\
(\mathrm{ug} / \mathrm{L} \text { or } \mathrm{ug} / \mathrm{kg}) \mathrm{ug} / \mathrm{L}\end{array}$ & $Q$ \\
\hline$===========$ & 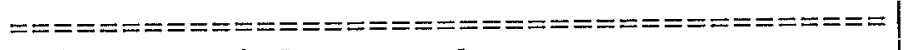 & $====================$ & $========$ \\
\hline $75-71-8$ & Dichlorodifluoromethane & 0.50 & U \\
\hline $74-87-3$ & Chloromethane & 0.50 & $\mathrm{U}$ \\
\hline $75-01-4$ & Vinyl chloride & 0.50 & $\mathrm{U}$ \\
\hline $74-83-9$ & Bromomethane & 0.50 & $\mathrm{U}$ \\
\hline $75-00-3$ & Chloroethane & 0.50 & $\mathrm{U}$ \\
\hline $75-69-4$ & Trichlorofluoromethane & 0.50 & U \\
\hline $75-35-4$ & 1,1-Dichloroethene & 0.50 & $\mathrm{U}$ \\
\hline $76-13-1$ & $1,1,2$-Trichloro-1,2,2-trifluoroethane & 0.50 & $\mathrm{U}$ \\
\hline $67-64-1$ & Acetone & 5.0 & $\mathrm{U}$ \\
\hline $75-15-0$ & Carbon disulfide & 0.50 & $\mathrm{U}$ \\
\hline $79-20-9$ & Methyl acetate & 0.50 & $\mathrm{U}$ \\
\hline $75-09-2$ & Methylene chloride & 0.50 & $\mathrm{U}$ \\
\hline $156-60-5$ & trans-1,2-Dichloroethene & 0.50 & $\mathrm{U}$ \\
\hline $1634-04-4$ & Methyl tert-butyl ether & 0.50 & $U$ \\
\hline $75-34-3$ & 1,1-Dichloroethane & 0.50 & U \\
\hline $156-59-2$ & cis-1,2-Dichloroethene & 0.50 & U \\
\hline $78-93-3$ & 2-Butanone & 5.0 & $\mathrm{U}$ \\
\hline $74-97-5$ & Bromochloromethane & 0.50 & $\mathrm{U}$ \\
\hline $67-66-3$ & Chloroform & 0.50 & U \\
\hline $71-55-6$ & $1,1,1$-Trichloroethane & 0.50 & $\mathrm{U}$ \\
\hline $110-82-7$ & Cyclohexane & 0.50 & $\mathrm{U}$ \\
\hline $56-23-5$ & Carbon tetrachloride & 0.50 & $\mathrm{U}$ \\
\hline $71-43-2$ & Benzene & 0.50 & $\mathrm{U}$ \\
\hline $107-06-2$ & 1,2-Dichloroethane & 0.50 & $\mathrm{U}$ \\
\hline
\end{tabular}

Report 1,4-Dioxane for Low-Medium VOA analysis only 
Lab Name: TESTAMERICA BURLINGTON

Contract : 8E-00302

Lab Code: STLV Case No.: BARNES Mod. Ref No.:

SDG No.: 132283

Matrix: (SOIL/SED/WATER) Water

Sample wt/vol: $25.0 \quad(\mathrm{~g} / \mathrm{mL}) \mathrm{mL}$

Leve1: (TRACE/LOW/MED) TRACE

\% Moisture: not dec.

GC Column: DB-624

ID : 0.53

Soil Extract Volume:

Purge Volume: 25.0
Lab Sample ID: 798782

Lab File ID: 798782

Date Received: 06/19/2009

Date Analyzed: 06/24/2009

Dilution Factor: 1.0

(uL) Soil Aliquot Volume:

(uL)

(mL)

\begin{tabular}{|c|c|c|c|}
\hline CAS NO. & COMPOUND & $\begin{array}{l}\text { CONCENTRATION UNITS : } \\
(\mathrm{ug} / \mathrm{L} \text { or } \mathrm{ug} / \mathrm{kg}) \mathrm{ug} / \mathrm{L}\end{array}$ & $Q$ \\
\hline$============$ & 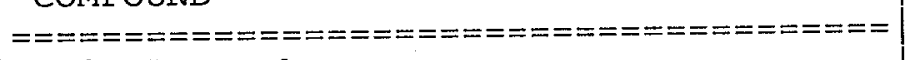 & 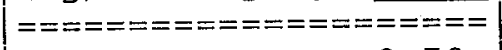 & $========$ \\
\hline $79-01-6$ & Trichloroethene & 0.50 & U \\
\hline $108-87-2$ & Methylcyclohexane & 0.50 & $\mathrm{U}$ \\
\hline $78-87-5$ & 1,2-Dichloropropane & 0.50 & U \\
\hline $75-27-4$ & Bromodichloromethane & 0.50 & $\mathrm{U}$ \\
\hline $10061-01-5$ & cis-1,3-Dichloropropene & 0.50 & $\mathrm{U}$ \\
\hline $108-10-1$ & 4 -Methyl-2-pentanone & 5.0 & U \\
\hline $108-88-3$ & Toluene & 0.50 & U \\
\hline $10061-02-6$ & trans-1,3-Dichloropropene & 0.50 & U \\
\hline $79-00-5$ & $1,1,2$-Trichloroethane & 0.50 & U \\
\hline $127-18-4$ & Tetrachloroethene & 0.50 & $\dot{U}$ \\
\hline $591-78-6$ & 2-Hexanone & 5.0 & $\mathrm{U}$ \\
\hline $124-48-1$ & Dibromochloromethane & 0.50 & $\mathrm{U}$ \\
\hline $106-93-4$ & 1,2-Dibromoethane & 0.50 & $\mathrm{U}$ \\
\hline $108-90-7$ & Chlorobenzene & 0.50 & $\mathrm{U}$ \\
\hline $100-41-4$ & Ethylbenzene & 0.50 & $\mathrm{U}$ \\
\hline $95-47-6$ & o-Xylene & 0.50 & $\mathrm{U}$ \\
\hline $179601-23-1$ & $\mathrm{~m}, \mathrm{p}$-Xylene & 0.50 & $\mathrm{U}$ \\
\hline $100-42-5$ & styrene & 0.50 & $\mathrm{U}$ \\
\hline $75-25-2$ & Bromoform & 0.50 & $\mathrm{U}$ \\
\hline $98-82-8$ & Isopropylbenzene & 0.50 & $\mathrm{U}$ \\
\hline $79-34-5$ & $1,1,2,2$-Tetrachloroethane & 0.50 & $\mathrm{U}$ \\
\hline $541-73-1$ & 1,3-Dichlorobenzene & 0.50 & $\mathrm{U}$ \\
\hline $106-46-7$ & 1,4-Dichlorobenzene & 0.50 & $\mathrm{U}$ \\
\hline $95-50-1$ & 1,2-Dichlorobenzene & 0.50 & $\mathrm{U}$ \\
\hline $96-12-8$ & 1,2-Dibromo-3-chloropropane & 0.50 & $\mathrm{U}$ \\
\hline $120-82-1$ & $1,2,4$-Trichlorobenzene & 0.50 & $\mathrm{U}$ \\
\hline $87-61-6$ & $1,2,3$-Trichlorobenzene & 0.50 & $\mathrm{U}$ \\
\hline
\end{tabular}


$1 A$ - FORM I VOA-1

VOLATILE ORGANICS ANALYSIS DATA SHEET

EPA SAMPLE NO.

Lab Name: TESTAMERICA BURLINGTON

Contract: 8E-00302

Lab Code: STLV Case No.: BARNES Mod. Ref No.:

SDG No. : 132283

Matrix: (SOIL/SED/WATER) Water

Lab Sample ID: 798783

Sample wt/vol: $25.0 \quad(\mathrm{~g} / \mathrm{mL}) \mathrm{mL}$

Lab File ID: 798783

Level: (TRACE/LOW/MED) TRACE

Date Received: 06/19/2009

\% Moisture: not dec.

Date Analyzed: 06/24/2009

GC Column: DB-624 ID: 0.53 (mm) Dilution Factor: 1.0

Soil Extract Volume:

(uL) Soil Aliquot Volume:

Purge Volume: 25.0

$(\mathrm{mL})$

\begin{tabular}{|c|c|c|c|}
\hline $\begin{array}{l}\text { CAS NO. } \\
========= \\
75-71-8 \\
74-87-3 \\
75-01-4 \\
74-83-9 \\
75-00-3 \\
75-69-4 \\
75-35-4 \\
76-13-1 \\
67-64-1 \\
75-15-0 \\
79-20-9 \\
75-09-2 \\
156-60-5 \\
1634-04-4 \\
75-34-3 \\
156-59-2 \\
78-93-3 \\
74-97-5 \\
67-66-3 \\
71-55-6 \\
110-82-7 \\
56-23-5 \\
71-43-2 \\
107-06-2\end{array}$ & $\begin{array}{l}\text { COMPOUND } \\
=========================== \\
\text { Dichlorodifluoromethane } \\
\text { Chloromethane } \\
\text { Vinyl chloride } \\
\text { Bromomethane } \\
\text { Chloroethane } \\
\text { Trichlorofluoromethane } \\
1,1-D i c h l o r o e t h e n e \\
1,1,2-\text { Trichloro-1, } 2,2-\text { trifluoroethane } \\
\text { Acetone } \\
\text { Carbon disulfide } \\
\text { Methyl acetate } \\
\text { Methylene chloride } \\
\text { trans-1, } 2 \text {-Dichloroethene } \\
\text { Methyl tert-butyl ether } \\
1,1-D i c h l o r o e t h a n e \\
\text { cis-1, } 2 \text {-Dichloroethene } \\
2-\text { Butanone } \\
\text { Bromochloromethane } \\
\text { Chloroform } \\
1,1,1-\text { Trichloroethane } \\
\text { Cyclohexane } \\
\text { Carbon tetrachloride } \\
\text { Benzene } \\
1,2-D i c h l o r o e t h a n e\end{array}$ & $\begin{array}{|cr|}\text { CONCENTRATION UNITS: } \\
\text { (ug } / \mathrm{L} \text { or ug } / \mathrm{kg}) & \text { ug } / \mathrm{L} \\
================ \\
0.50 \\
0.50 \\
0.50 \\
0.50 \\
0.50 \\
0.50 \\
0.50 \\
0.50 \\
5.0 \\
0.50 \\
0.50 \\
0.50 \\
0.50 \\
0.50 \\
0.50 \\
0.50 \\
5.0 \\
0.50 \\
0.50 \\
0.50 \\
0.50 \\
0.50 \\
0.50 \\
0.50\end{array}$ & $\begin{array}{l}====== \\
U \\
U \\
U \\
U \\
U \\
U \\
U \\
U \\
U \\
U \\
U \\
U \\
U \\
U \\
U \\
U \\
U \\
U \\
U \\
U \\
U \\
U \\
U \\
U\end{array}$ \\
\hline
\end{tabular}

Report 1,4-Dioxane for Low-Medium VOA analysis only 
$1 B$ - FORM I VOA-2

VOLATILE ORGANICS ANALYSIS DATA SHEET

Lab Name: TESTAMERICA BURLINGTON

Lab Code: STLV Case No.: BARNES

Matrix: (SOIL/SED/WATER) water

Sample wt/vol: $25.0 \quad(\mathrm{~g} / \mathrm{mL}) \mathrm{mL}$

LeVel: (TRACE/LOW/MED) TRACE

\% Moisture: not dec.

GC Column: DB-624

Soil Extract Volume:

ID $: 0.53$

Purge Volume: 25.0
Contract: $8 \mathrm{E}-00302$

Mod. Ref No.:
SDG No.: 132283
Lab Sample ID: 798783

Lab File ID: 798783

Date Received: 06/19/2009

Date Analyzed: 06/24/2009

Dilution Factor: 1.0

(uL) Soil Aliquot Volume:

(uI)

(m工)

\begin{tabular}{|c|c|c|c|}
\hline $\begin{array}{l}\text { CAS NO. } \\
===========\end{array}$ & COMPOUND & $\begin{array}{l}\text { CONCENTRATION UNITS: } \\
(\mathrm{ug} / \mathrm{L} \text { or } \mathrm{ug} / \mathrm{kg}) \mathrm{ug} / \mathrm{L}\end{array}$ & Q \\
\hline $\begin{array}{c}========== \\
79-01-6\end{array}$ & 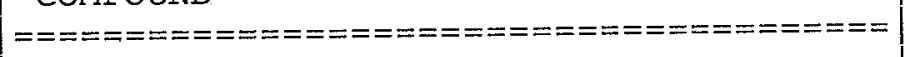 & $===================0$ & $========$ \\
\hline $\begin{array}{r}79-01-6 \\
108-87-2\end{array}$ & Trichloroethene & 0.50 & $\mathrm{U}$ \\
\hline $\begin{array}{r}108-87-2 \\
78-87-5\end{array}$ & Methylcyclohexane & 0.50 & U \\
\hline $\begin{array}{l}78-87-5 \\
75-27-4\end{array}$ & 1,2-Dichloropropane & 0.50 & $U$ \\
\hline $\begin{array}{r}75-27-4 \\
10061-01-5\end{array}$ & Bromodichloromethane & 0.50 & U \\
\hline $\begin{array}{r}10061-01-5 \\
108-10-1\end{array}$ & cis-1,3-Dichloropropene & 0.50 & U \\
\hline $\begin{array}{l}108-10-1 \\
108-88-3\end{array}$ & 4-Methyl-2-pentanone & 5.0 & $\mathrm{U}$ \\
\hline $108-88-3$ & Toluene & 0.50 & U \\
\hline $10061-02-6$ & trans-1,3-Dichloropropene & 0.50 & $\mathrm{U}$ \\
\hline $79-00-5$ & $1,1,2$-Trichloroethane & .0 .50 & $U$ \\
\hline $127-18-4$ & Tetrachloroethene & 0.50 & $\mathrm{U}$ \\
\hline $591-78-6$ & 2-Hexanone & 5.0 & $\mathrm{U}$ \\
\hline $124-48-1$ & Dibromochloromethane & 0.50 & $\mathrm{U}$ \\
\hline $106-93-4$ & 1,2-Dibromoethane & 0.50 & U \\
\hline $108-90-7$ & Chlorobenzene & 0.50 & U \\
\hline $100-41-4$ & Ethylbenzene & 0.50 & $\mathrm{U}$ \\
\hline $95-47-6$ & o-Xylene & 0.50 & U \\
\hline $179601-23-1$ & $\mathrm{~m}, \mathrm{p}$-Xylene & 0.50 & $\mathrm{U}$ \\
\hline $100-42-5$ & Styrene & 0.50 & U \\
\hline $75-25-2$ & Bromoform & 0.50 & $\mathrm{U}$ \\
\hline $98-82-8$ & Isopropylbenzene & 0.50 & $\mathrm{U}$ \\
\hline $79-34-5$ & $1,1,2,2$-Tetrachloroethane & 0.50 & $\mathrm{U}$ \\
\hline $541-73-1$ & 1,3-Dichlorobenzene & 0.50 & $\mathrm{U}$ \\
\hline $106-46-7$ & 1,4-Dichlorobenzene & 0.50 & $\mathrm{U}$ \\
\hline $95-50-1$ & 1,2-Dichlorobenzene & 0.50 & $\mathrm{U}$ \\
\hline $96-12-8$ & 1,2-Dibromo-3-chloropropane & 0.50 & $\mathrm{U}$ \\
\hline $120-82-1$ & $1,2,4$-Trichlorobenzene & 0.50 & $\mathrm{U}$ \\
\hline $87-61-6$ & $1,2,3$-Trichlorobenzene & 0.50 & $\mathrm{U}$ \\
\hline
\end{tabular}


$1 A$ - FORM I VOA-1

VOLATILE ORGANICS ANALYSIS DATA SHEET

Lab Name: TESTAMERICA BURLINGTON

Lab Code: STLV Case No.: BARNES

Matrix: (SOIL/SED/WATER) water

Sample wt/vol: $25.0(\mathrm{~g} / \mathrm{mL}) \mathrm{mL}$

Level : (TRACE/LOW/MED) TRACE

\% Moisture: not dec.

GC Column: DB-624

ID $: 0.53$

Soil Extract Volume:

Purge Volume: 25.0
Contract: 8E-00302

Mod. Ref No.:
SDG No.: 132283
Lab Sample ID: 798784

Lab File ID: 798784

Date Received: 06/19/2009

Date Analyzed: 06/24/2009

Dilution Factor: 1.0

(uL) Soil Aliquot Volume:

(uL)

\begin{tabular}{|c|c|c|c|}
\hline $\begin{array}{l}\text { CAS NO. } \\
========= \\
75-71-8 \\
74-87-3 \\
75-01-4 \\
74-83-9 \\
75-00-3 \\
75-69-4 \\
75-35-4 \\
76-13-1 \\
67-64-1 \\
75-15-0 \\
79-20-9 \\
75-09-2 \\
156-60-5 \\
1634-04-4 \\
75-34-3 \\
156-59-2 \\
78-93-3 \\
74-97-5 \\
67-66-3 \\
71-55-6 \\
110-82-7 \\
56-23-5 \\
71-43-2 \\
107-06-2\end{array}$ & \begin{tabular}{|l|} 
COMPOUND \\
$===========================$ \\
Dichlorodifluoromethane \\
Chloromethane \\
Vinyl chloride \\
Bromomethane \\
Chloroethane \\
Trichlorofluoromethane \\
1,1-Dichloroethene \\
1, $1,2-$ Trichloro-1, $2,2-$ trifluoroethane \\
Acetone \\
Carbon disulfide \\
Methyl acetate \\
Methylene chloride \\
trans-1,2-Dichloroethene \\
Methyl tert-butyl ether \\
$1,1-D i c h l o r o e t h a n e$ \\
cis-1, 2 -Dichloroethene \\
$2-$ Butanone \\
Bromochloromethane \\
Chloroform \\
$1,1,1-$ Trichloroethane \\
Cyclohexane \\
Carbon tetrachloride \\
Benzene \\
$1,2-D i c h l o r o e t h a n e$
\end{tabular} & $\begin{array}{|cc|}\text { CONCENTRATION UNITS: } \\
\text { (ug/L or ug/kg) } & \text { ug/L } \\
================== \\
0.50 \\
0.50 \\
0.50 \\
0.50 \\
0.50 \\
0.50 \\
0.50 \\
0.50 \\
5.0 \\
0.50 \\
0.50 \\
0.50 \\
0.50 \\
0.50 \\
0.50 \\
0.50 \\
5.0 \\
0.50 \\
0.50 \\
0.50 \\
0.50 \\
0.91 \\
0.50 \\
0.50\end{array}$ & \begin{tabular}{|l}
$======$ \\
$U$ \\
$U$ \\
$U$ \\
$U$ \\
$U$ \\
$U$ \\
$U$ \\
$U$ \\
$U$ \\
$U$ \\
$U$ \\
$U$ \\
$U$ \\
$U$ \\
$U$ \\
$U$ \\
$U$ \\
$U$ \\
$U$ \\
$U$ \\
$U$ \\
$U$ \\
$U$
\end{tabular} \\
\hline
\end{tabular}

Report 1,4-Dioxane for Low-Medium VOA analysis only 
Lab Name: TESTAMERICA BURLINGTON

Lab Code: STLV Case No.: BARNES

Matrix: (SOIL/SED/WATER) Water

Sample wt/vol: $25.0 \quad(\mathrm{~g} / \mathrm{mL}) \mathrm{mL}$

Level : (TRACE/LOW/MED) TRACE

\% Moisture: not dec.

GC Column: DB-624

ID : 0.53

Soil Extract Volume:

Purge Volume: 25.0
Contract: $8 \mathrm{E}-00302$

Mod. Ref No.:
SDG No.: 132283
Lab Sample ID: 798784

Lab File ID: 798784

Date Received: 06/19/2009

Date Analyzed: 06/24/2009

Dilution Factor: 1.0

Soil Aliquot Volume:

(mL)

\begin{tabular}{|c|c|c|c|}
\hline CAS NO. & COMPOUND & $\begin{array}{l}\text { CONCENTRATION UNITS: } \\
(\mathrm{ug} / \mathrm{L} \text { or } \mathrm{ug} / \mathrm{kg}) \mathrm{ug} / \mathrm{L}\end{array}$ & $Q$ \\
\hline$===========$ & 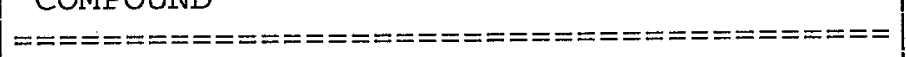 & $========0===========$ & $=======$ \\
\hline $79-01-6$ & Trichloroethene & 0.50 & $\mathrm{U}$ \\
\hline $108-87-2$ & Methylcyclohexane & 0.50 & $\mathrm{U}$ \\
\hline $78-87-5$ & 1,2-Dichloropropane & 0.50 & U \\
\hline $75-27-4$ & Bromodichloromethane & 0.50 & U \\
\hline $10061-01-5$ & cis-1,3-Dichloropropene & 0.50 & $\mathrm{U}$ \\
\hline $108-10-1$ & 4-Methyl-2-pentanone & 5.0 & $\mathrm{U}$ \\
\hline $108-88-3$ & Toluene & 0.50 & $\mathrm{U}$ \\
\hline $10061-02-6$ & trans-1,3-Dichloropropene & 0.50 & $\mathrm{U}$ \\
\hline $79-00-5$ & 1,1,2-Trichloroethane & 0.50 & $\mathrm{U}$ \\
\hline $127-18-4$ & Tetrachloroethene & 0.50 & $\mathrm{U}$ \\
\hline $591-78-6$ & 2 -Hexanone & 5.0 & $\mathrm{U}$ \\
\hline $124-48-1$ & Dibromochloromethane & 0.50 & $\mathrm{U}$ \\
\hline $106-93-4$ & 1,2-Dibromoethane & 0.50 & $\mathrm{U}$ \\
\hline $108-90-7$ & Chlorobenzene & 0.50 & $\mathrm{U}$ \\
\hline $100-41-4$ & Ethylbenzene & 0.50 & $\mathrm{U}$ \\
\hline $95-47-6$ & o-xylene & 0.50 & $\mathrm{U}$ \\
\hline $179601-23-1$ & $\mathrm{~m}, \mathrm{p}$-Xylene & 0.50 & $U$ \\
\hline $100-42-5$ & Styrene & 0.50 & $\mathrm{U}$ \\
\hline $75-25-2$ & Bromoform & 0.50 & U \\
\hline $98-82-8$ & Isopropylbenzene & 0.50 & $\mathrm{U}$ \\
\hline $79-34-5$ & $1,1,2,2$-Tetrachloroethane & 0.50 & U \\
\hline $541-73-1$ & 1,3-Dichlorobenzene & 0.50 & $\mathrm{U}$ \\
\hline $106-46-7$ & 1,4-Dichlorobenzene & 0.50 & $\mathrm{U}$ \\
\hline $95-50-1$ & 1,2-Dichlorobenzene & 0.50 & U \\
\hline $96-12-8$ & 1,2-Dibromo-3-chloropropane & 0.50 & $\mathrm{U}$ \\
\hline $120-82-1$ & $1,2,4$-Trichlorobenzene & 0.50 & $\mathrm{U}$ \\
\hline $87-61-6$ & 1,2,3-Trichlorobenzene & 0.50 & $\mathrm{U}$ \\
\hline
\end{tabular}


$1 A$ - FORM I VOA-I

VOLATILE ORGANICS ANALYSIS DATA SHEET
EPA SAMPLE NO.

BAQCTBW28674
Lab Name: TESTAMERICA BURLINGTON

Lab Code: STLV Case No.: BARNES

Matrix: (SOIL/SED/WATER) Water

Sample wt/vol: $25.0 \quad(\mathrm{~g} / \mathrm{mL}) \mathrm{mL}$

Level: (TRACE/LOW/MED) TRACE

\% Moisture: not dec.

GC Column: DB-624

ID $: 0.53$

Soil Extract Volume:

Purge Volume: 25.0
Contract : $8 E-00302$

Mod. Ref No.:
SDG No.: 132283
Lab Sample ID: 798785

Lab File ID: 798785

Date Received: 06/19/2009

Date Analyzed: 06/24/2009

Dilution Factor: 1.0

Soil Aliquot Volume:

(uL)

\begin{tabular}{|c|c|c|c|}
\hline \begin{tabular}{|r|} 
CAS NO. \\
$=========$ \\
$75-71-8$ \\
$74-87-3$ \\
$75-01-4$ \\
$74-83-9$ \\
$75-00-3$ \\
$75-69-4$ \\
$75-35-4$ \\
$76-13-1$ \\
$67-64-1$ \\
$75-15-0$ \\
$79-20-9$ \\
$75-09-2$ \\
$156-60-5$ \\
$1634-04-4$ \\
$75-34-3$ \\
$156-59-2$ \\
$78-93-3$ \\
$74-97-5$ \\
$67-66-3$ \\
$71-55-6$ \\
$110-82-7$ \\
$56-23-5$ \\
$71-43-2$ \\
$107-06-2$
\end{tabular} & $\begin{array}{l}\text { COMPOUND } \\
=============================== \\
\text { Dichlorodifluoromethane } \\
\text { Chloromethane } \\
\text { Vinyl chloride } \\
\text { Bromomethane } \\
\text { Chloroethane } \\
\text { Trichlorofluoromethane } \\
\text { 1,1-Dichloroethene } \\
\text { 1,1,2-Trichloro-1,2,2-trifluoroethane } \\
\text { Acetone } \\
\text { Carbon disulfide } \\
\text { Methyl acetate } \\
\text { Methylene chloride } \\
\text { trans-1,2-Dichloroethene } \\
\text { Methyl tert-butyl ether } \\
1,1-D i c h l o r o e t h a n e \\
\text { cis-1,2-Dichloroethene } \\
2-\text { Butanone } \\
\text { Bromochloromethane } \\
\text { Chloroform } \\
\text { 1,1,1-Trichloroethane } \\
\text { Cyclohexane } \\
\text { Carbon tetrachloride } \\
\text { Benzene } \\
1,2-D i c h l o r o e t h a n e\end{array}$ & 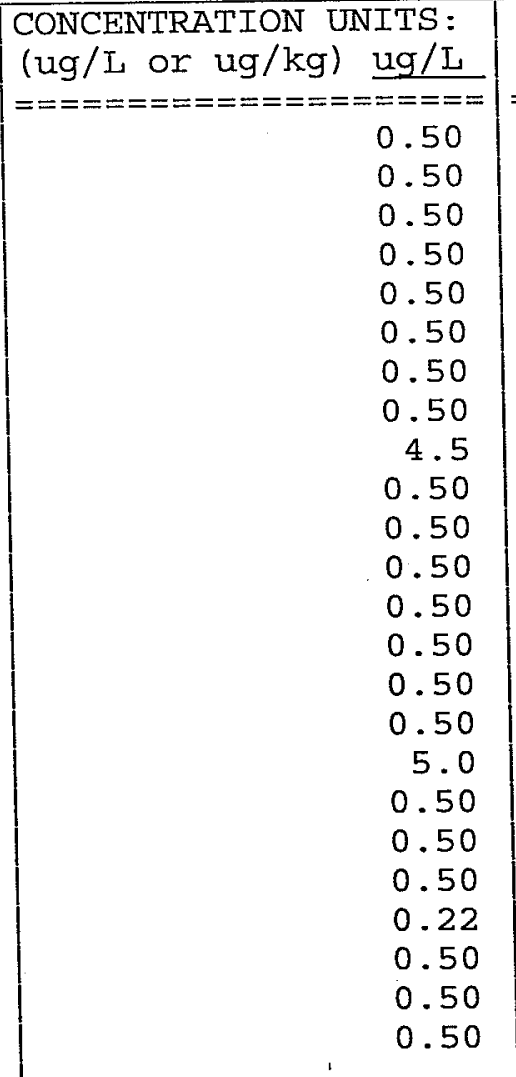 & $\begin{array}{c}======= \\
U \\
U \\
U \\
U \\
U \\
U \\
U \\
U \\
J \\
U \\
U \\
U \\
U \\
U \\
U \\
U \\
U \\
U \\
U \\
U \\
J \\
U \\
U \\
U\end{array}$ \\
\hline
\end{tabular}

Report 1,4-Dioxane for Low-Medium VOA analysis only 
Lab Name: TESTAMERICA BURLINGTON

Iab Code: STLV Case No.: BARNES

Matrix: (SOIL/SED/WATER) Water

Sample wt/vol: $25.0 \quad(\mathrm{~g} / \mathrm{mL}) \mathrm{mL}$

Leve1: (TRACE/LOW/MED) TRACE

\% Moisture: not dec.

GC Column: DB-624

ID: 0.53

Soil Extract Volume:

Purge Volume: 25.0
Contract: $8 \mathrm{E}-00302$

Mod. Ref No.:
SDG No.: 132283
Lab Sample ID: 798785

Lab File ID: 798785

Date Received: 06/19/2009

Date Analyzed: 06/24/2009

Dilution Factor: 1.0

Soil Aliquot Volume:

(uI)

\begin{tabular}{|c|c|c|c|}
\hline \begin{tabular}{|} 
CAS NO. \\
$==========$ \\
$79-01-6$ \\
$108-87-2$ \\
$78-87-5$ \\
$75-27-4$ \\
$10061-01-5$ \\
$108-10-1$ \\
$108-88-3$ \\
$10061-02-6$ \\
$79-00-5$ \\
$127-18-4$ \\
$591-78-6$ \\
$124-48-1$ \\
$106-93-4$ \\
$108-90-7$ \\
$100-41-4$ \\
$95-47-6$ \\
$179601-23-1$ \\
$100-42-5$ \\
$75-25-2$ \\
$98-82-8$ \\
$79-34-5$ \\
$541-73-1$ \\
$106-46-7$ \\
$95-50-1$ \\
$96-12-8$ \\
$120-82-1$ \\
$87-61-6$
\end{tabular} & 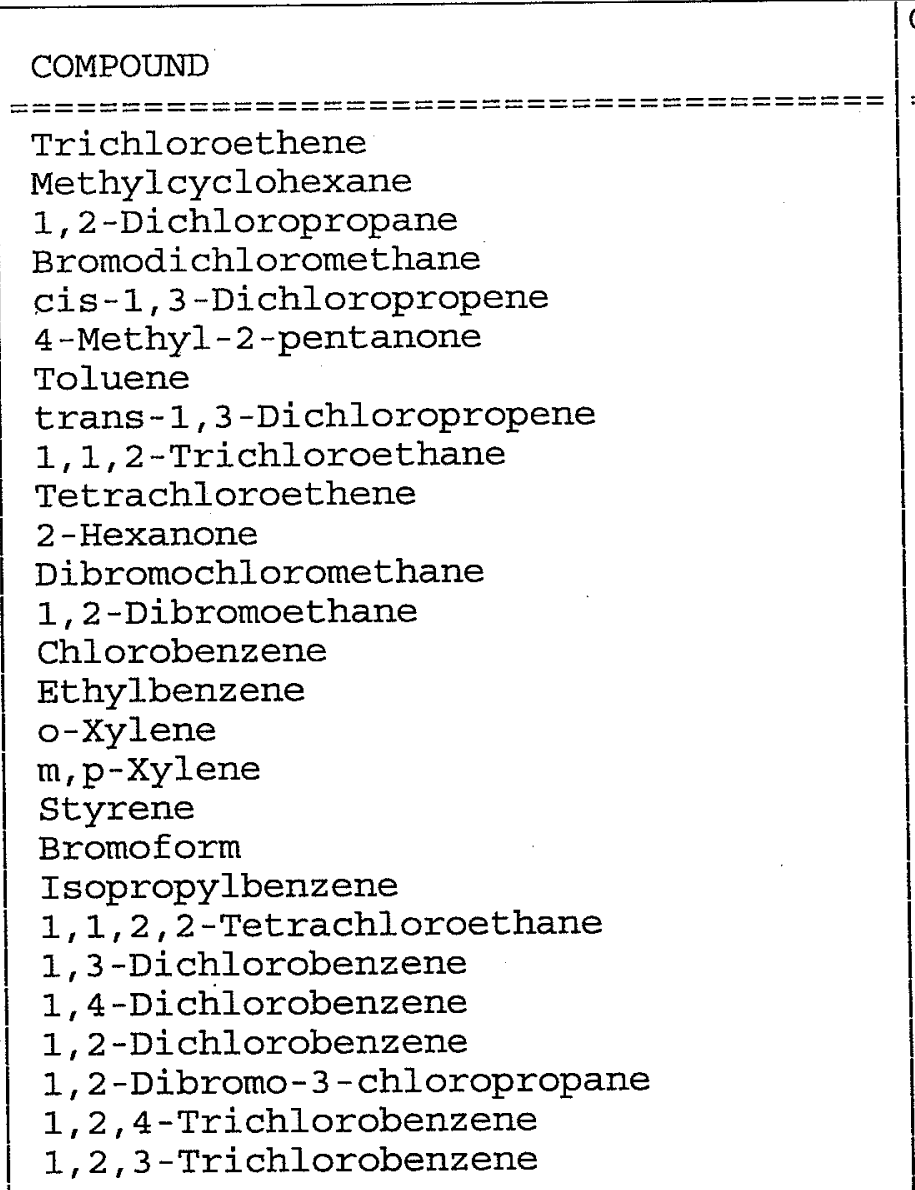 & 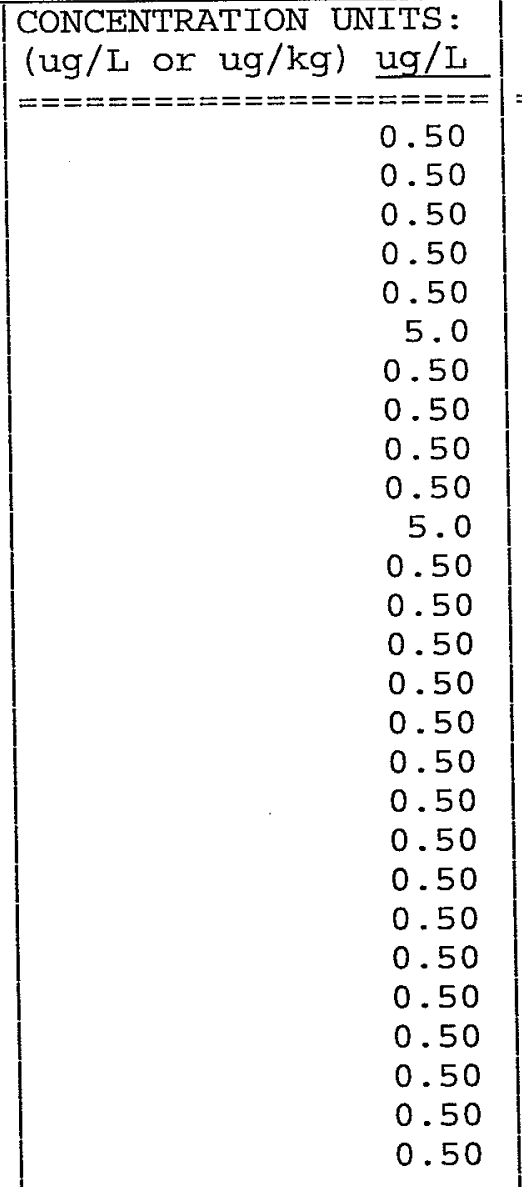 & 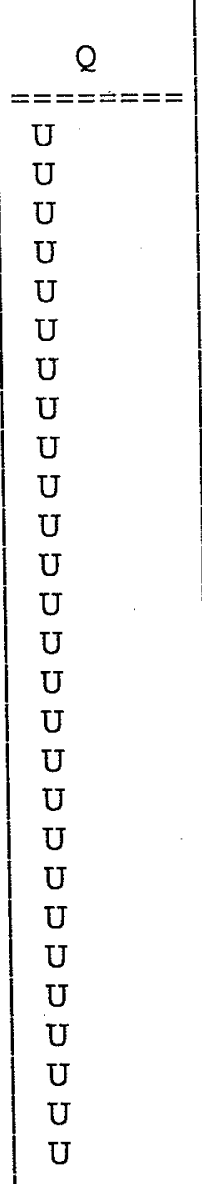 \\
\hline
\end{tabular}


$1 A$ - FORM I VOA-I

VOLATILE ORGANICS ANALYSIS DATA SHEET

Lab Name: TESTAMERICA BURLINGTON

Lab Code: STLV Case No.: BARNES

Matrix: (SOIL/SED/WATER) water

Sample wt/vol: $25.0 \quad(\mathrm{~g} / \mathrm{mL}) \mathrm{mL}$

Level: (TRACE/LOW/MED) TRACE

\% Moisture: not dec.

GC Column: DB-624

ID $: 0.53$

Soil Extract Volume:

Purge Volume: 25.0
Contract: $8 E-00302$

Mod. Ref No.:
SDG NO.: 132283
Lab Sample ID: 798786

Lab File ID: 798786

Date Received: 06/19/2009

Date Analyzed: 06/24/2009

Dilution Factor: 1.0

Soil Aliquot Volume:

\begin{tabular}{|c|c|c|c|}
\hline $\begin{array}{c}\text { CAS NO. } \\
========== \\
75-71-8 \\
74-87-3 \\
75-01-4 \\
74-83-9 \\
75-00-3 \\
75-69-4 \\
75-35-4 \\
76-13-1 \\
67-64-1 \\
75-15-0 \\
79-20-9 \\
75-09-2 \\
156-60-5 \\
1634-04-4 \\
75-34-3 \\
156-59-2 \\
78-93-3 \\
74-97-5 \\
67-66-3 \\
71-55-6 \\
110-82-7 \\
56-23-5 \\
71-43-2 \\
107-06-2\end{array}$ & $\begin{array}{l}\text { COMPOUND } \\
=============================\mid \\
\text { Dichlorodifluoromethane } \\
\text { Chloromethane } \\
\text { Vinyl chloride } \\
\text { Bromomethane } \\
\text { Chloroethane } \\
\text { Trichlorofluoromethane } \\
1,1-\text { Dichloroethene } \\
1,1,2-\text { Trichloro-1,2,2-trifluoroethane } \\
\text { Acetone } \\
\text { Carbon disulfide } \\
\text { Methyl acetate } \\
\text { Methylene chloride } \\
\text { trans-1,2-Dichloroethene } \\
\text { Methyl tert-butyl ether } \\
1,1-D i c h l o r o e t h a n e \\
\text { cis-1,2-Dichloroethene } \\
2-\text { Butanone } \\
\text { Bromochloromethane } \\
\text { Chloroform } \\
1,1,1-\text { Trichloroethane } \\
\text { Cyclohexane } \\
\text { Carbon tetrachloride } \\
\text { Benzene } \\
1,2-D i c h l o r o e t h a n e\end{array}$ & $\begin{array}{|cc|}\text { CONCENTRATION UNITS: } \\
\text { (ug } / \mathrm{L} \text { or ug } / \mathrm{kg} \text { ) } & \underline{u g} / \mathrm{L} \\
=============== \\
0.50 \\
0.50 \\
0.50 \\
0.50 \\
0.50 \\
0.50 \\
0.50 \\
0.50 \\
5.0 \\
0.50 \\
0.50 \\
0.50 \\
0.50 \\
0.50 \\
0.50 \\
0.50 \\
5.0 \\
0.50 \\
0.50 \\
0.50 \\
0.50 \\
0.27 \\
0.50 \\
0.50\end{array}$ & $\begin{array}{l}======= \\
U \\
U \\
U \\
U \\
U \\
U \\
U \\
U \\
U \\
U \\
U \\
U \\
U \\
U \\
U \\
U \\
U \\
U \\
U \\
U \\
U \\
J \\
U \\
U\end{array}$ \\
\hline
\end{tabular}

Report 1,4-Dioxane for Low-Medium VOA analysis only 
Lab Name: TESTAMERICA BURLINGTON

Lab Code: STLV Case No.: BARNES

Matrix: (SOIL/SED/WATER) Water

Sample wt/vol: 25.0

$(\mathrm{g} / \mathrm{mL}) \mathrm{mL}$

Level: (TRACE/LOW/MED) TRACE

\% Moisture: not dec.

GC Column: DB-624

ID : 0.53

Soil Extract Volume:

Purge Volume: 25.0
Contract: 8E-00302

Mod. Ref No.:
SDG No.: 132283
Lab Sample ID: 798786

Lab File ID: 798786

Date Received: 06/19/2009

Date Analyzed: 06/24/2009

Dilution Factor: 1.0

Soil Aliquot Volume:

(mL)

\begin{tabular}{|c|c|c|c|}
\hline \begin{tabular}{|} 
CAS NO. \\
$=========$ \\
$79-01-6$ \\
$108-87-2$ \\
$78-87-5$ \\
$75-27-4$ \\
$10061-01-5$ \\
$108-10-1$ \\
$108-88-3$ \\
$10061-02-6$ \\
$79-00-5$ \\
$127-18-4$ \\
$591-78-6$ \\
$124-48-1$ \\
$106-93-4$ \\
$108-90-7$ \\
$100-41-4$ \\
$95-47-6$ \\
$179601-23-1$ \\
$100-42-5$ \\
$75-25-2$ \\
$98-82-8$ \\
$79-34-5$ \\
$541-73-1$ \\
$106-46-7$ \\
$95-50-1$ \\
$96-12-8$ \\
$120-82-1$ \\
$87-61-6$
\end{tabular} & 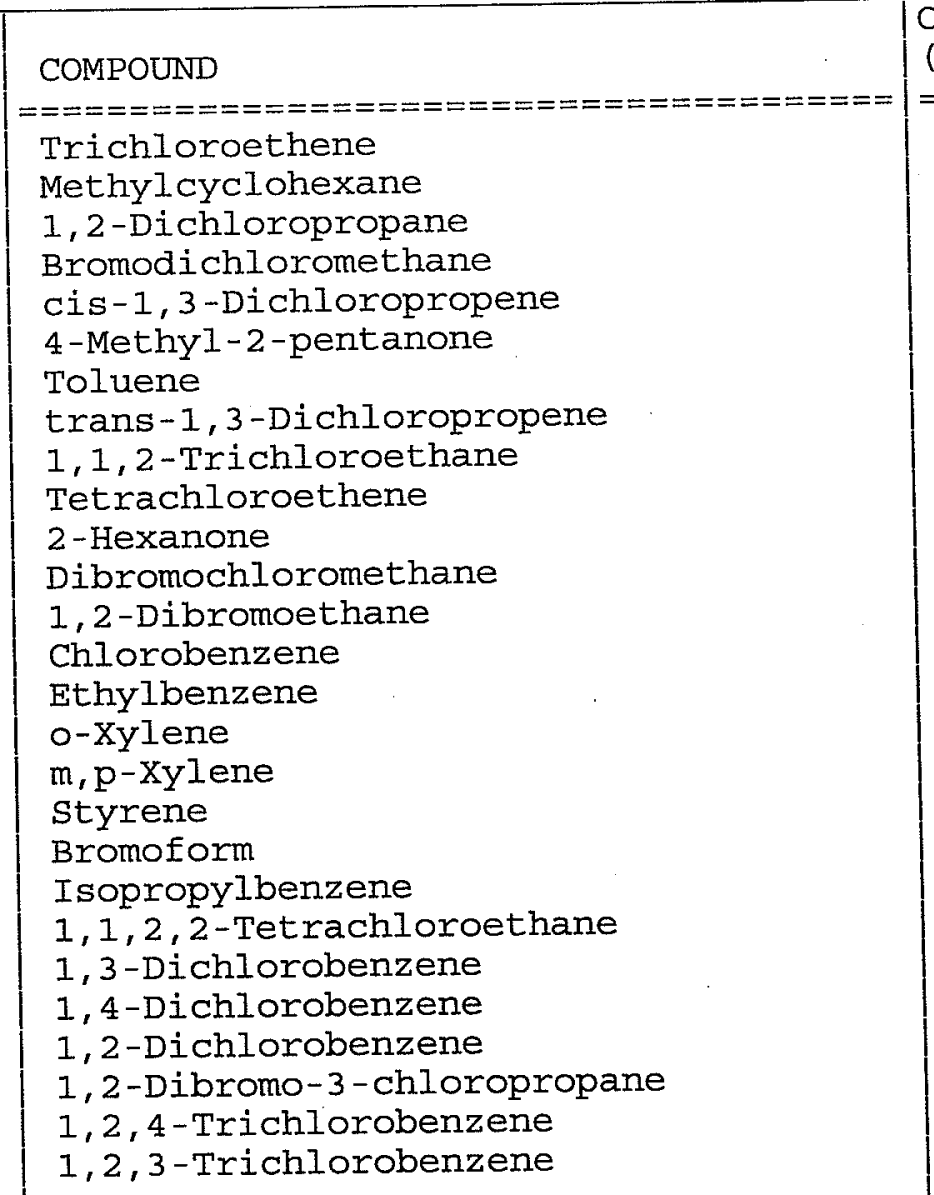 & \begin{tabular}{|cr} 
CONCENTRATION UNITS : \\
(ug/L or ug $/ \mathrm{kg})$ & $\mathrm{ug} / \mathrm{L}$ \\
$==================$ \\
0.50 \\
0.50 \\
0.50 \\
0.50 \\
0.50 \\
5.0 \\
0.50 \\
0.50 \\
0.50 \\
0.50 \\
5.0 \\
0.50 \\
0.50 \\
0.50 \\
0.50 \\
0.50 \\
0.50 \\
0.50 \\
0.50 \\
0.50 \\
0.50 \\
0.50 \\
0.50 \\
0.50 \\
0.50 \\
0.50 \\
0.50
\end{tabular} & \begin{tabular}{|l} 
Q \\
$======$ \\
$U$ \\
$U$ \\
$U$ \\
$U$ \\
$U$ \\
$U$ \\
$U$ \\
$U$ \\
$U$ \\
$U$ \\
$U$ \\
$U$ \\
$U$ \\
$U$ \\
$U$ \\
$U$ \\
$U$ \\
$U$ \\
$U$ \\
$U$ \\
$U$ \\
$U$ \\
$U$ \\
$U$ \\
$U$ \\
$U$ \\
$U$
\end{tabular} \\
\hline
\end{tabular}


$1 A$ - FORM I VOA-1

VOLATILE ORGANICS ANALYSIS DATA SHEET
EPA SAMPLE NO.

VHBLK01
Lab Name: TESTAMERICA BURLINGTON

Lab Code: STLV Case No.: BARNES

Matrix: (SOIL/SED/WATER) Water

Sample wt/vol: 25.0

$(\mathrm{g} / \mathrm{mL}) \mathrm{mL}$

Level : (TRACE/LOW/MED) TRACE

\% Moisture: not dec.

GC Column: DB-624

Soil Extract Volume:

ID : 0.53

(mm)

Contract : $8 \mathrm{E}-00302$

Mod. Ref No.:
SDG NO.: 132283

Purge Volume: 25.0

(uIs)

Lab Sample ID: 798787

Lab File ID: 798787

Date Received:

Date Analyzed: 06/24/2009

Dilution Factor: 1.0

Soil Aliquot Volume:

(uL)

(mL)

\begin{tabular}{|c|c|c|c|}
\hline $\begin{array}{l}\text { CAS NO. } \\
========== \\
75-71-8 \\
74-87-3 \\
75-01-4 \\
74-83-9 \\
75-00-3 \\
75-69-4 \\
75-35-4 \\
76-13-1 \\
67-64-1 \\
75-15-0 \\
79-20-9 \\
75-09-2 \\
156-60-5 \\
1634-04-4 \\
75-34-3 \\
156-59-2 \\
78-93-3 \\
74-97-5 \\
67-66-3 \\
71-55-6 \\
110-82-7 \\
56-23-5 \\
71-43-2 \\
107-06-2\end{array}$ & $\begin{array}{l}\text { COMPOUND } \\
=========================== \\
\text { Dichlorodifluoromethane } \\
\text { Chloromethane } \\
\text { Vinyl chloride } \\
\text { Bromomethane } \\
\text { Chloroethane } \\
\text { Trichlorofluoromethane } \\
1,1-D i \text { chloroethene } \\
1,1,2-\text { Trichloro-1, } 2,2-\text { trifluoroethane } \\
\text { Acetone } \\
\text { Carbon disulfide } \\
\text { Methyl acetate } \\
\text { Methylene chloride } \\
\text { trans-1,2-Dichloroethene } \\
\text { Methyl tert-butyl ether } \\
1,1-D i c h l o r o e t h a n e \\
\text { cis-1,2-Dichloroethene } \\
2-\text { Butanone } \\
\text { Bromochloromethane } \\
\text { Chloroform } \\
1,1,1-\text { Trichloroethane } \\
\text { Cyclohexane } \\
\text { Carbon tetrachloride } \\
\text { Benzene } \\
1,2-D i c h l o r o e t h a n e\end{array}$ & $\begin{array}{|cr|}\text { CONCENTRATION UNITS: } \\
\text { (ug } / \mathrm{L} \text { or ug/kg) } & \text { ug } / \mathrm{L} \\
================ \\
0.50 \\
0.50 \\
0.50 \\
0.50 \\
0.50 \\
0.50 \\
0.50 \\
0.50 \\
5.0 \\
0.50 \\
0.50 \\
0.50 \\
0.50 \\
0.50 \\
0.50 \\
0.50 \\
5.0 \\
0.50 \\
0.50 \\
0.50 \\
0.50 \\
0.50 \\
0.50 \\
0.50\end{array}$ & $\begin{array}{l}\text { Q }======== \\
\mathrm{U} \\
\mathrm{U} \\
\mathrm{U} \\
\mathrm{U} \\
\mathrm{U} \\
\mathrm{U} \\
\mathrm{U} \\
\mathrm{U} \\
\mathrm{U} \\
\mathrm{U} \\
\mathrm{U} \\
\mathrm{U} \\
\mathrm{U} \\
\mathrm{U} \\
\mathrm{U} \\
\mathrm{U} \\
\mathrm{U} \\
\mathrm{U} \\
\mathrm{U} \\
\mathrm{U} \\
\mathrm{U} \\
\mathrm{U} \\
\mathrm{U} \\
\mathrm{U}\end{array}$ \\
\hline
\end{tabular}

Report 1,4-Dioxane for Low-Medium VOA analysis only 
$1 B$ - FORM I VOA-2

VOLATILE ORGANICS ANALYSIS DATA SHEET
EPA SAMPLE NO.

VHBLKOI
Lab Name: TESTAMERICA BURLINGTON

Lab Code: STLV Case No.: BARNES

Matrix: (SOIL/SED/WATER) Water

Sample wt/vol: $25.0(\mathrm{~g} / \mathrm{mL}) \mathrm{mL}$

Level: (TRACE/LOW/MED) TRACE

\% Moisture: not dec.

GC Column: DB-624

ID $: 0.53$

Soil Extract Volume:

Purge Volume: 25.0
Contract: 8E-00302

Mod. Ref No.:
SDG NO.: 132283
Lab Sample ID: 798787

Lab File ID: 798787

Date Received:

Date Analyzed: 06/24/2009

Dilution Factor: 1.0

Soil Aliquot Volume:

$(\mathrm{mL})$

\begin{tabular}{|c|c|c|c|}
\hline CAS NO. & COMPOUND & $\begin{array}{l}\text { CONCENTRATION UNITS: } \\
(\mathrm{ug} / \mathrm{L} \text { or } \mathrm{ug} / \mathrm{kg}) \mathrm{ug} / \mathrm{L}\end{array}$ & Q \\
\hline$===========$ & 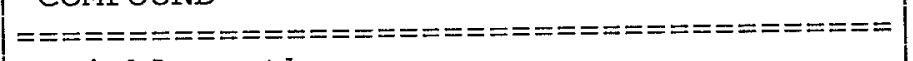 & 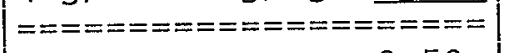 & $=======$ \\
\hline $79-01-6$ & Trichloroethene & 0.50 & U \\
\hline $108-87-2$ & Methylcyclohexane & 0.50 & $\mathrm{U}$ \\
\hline $78-87-5$ & 1,2-Dichloropropane & 0.50 & $\mathrm{U}$ \\
\hline $75-27-4$ & Bromodichloromethane & 0.50 & $\mathrm{U}$ \\
\hline $10061-01-5$ & cis-1,3-Dichloropropene & 0.50 & $\mathrm{U}$ \\
\hline $108-10-1$ & 4-Methyl-2-pentanone & 5.0 & $\mathrm{U}$ \\
\hline $108-88-3$ & Toluene & 0.50 & $\mathrm{U}$ \\
\hline $10061-02-6$ & trans-1,3-Dichloropropene & 0.50 & $\mathrm{U}$ \\
\hline $79-00-5$ & $1,1,2$-Trichloroethane & 0.50 & $\mathrm{U}$ \\
\hline $127-18-4$ & Tetrachloroethene & 0.50 & $\mathrm{U}$ \\
\hline $591-78-6$ & 2-Hexanone & $5: 0$ & $\mathrm{U}$ \\
\hline $124-48-1$ & Dibromochloromethane & 0.50 & $\mathrm{U}$ \\
\hline $106-93-4$ & 1,2 -Dibromoethane & 0.50 & $\mathrm{U}$ \\
\hline $108-90-7$ & Chlorobenzene & 0.50 & U \\
\hline $100-41-4$ & Ethylbenzene & 0.50 & U \\
\hline $95-47-6$ & o-xylene & 0.50 & U \\
\hline $179601-23-1$ & $\mathrm{~m}, \mathrm{p}$-Xylene & 0.50 & U \\
\hline $100-42-5$ & Styrene & 0.50 & U \\
\hline $75-25-2$ & Bromoform & 0.50 & $\mathrm{U}$ \\
\hline $98-82-8$ & Isopropylbenzene & 0.50 & $\mathrm{U}$ \\
\hline $79-34-5$ & $1,1,2,2$-Tetrachloroethane & 0.50 & $\mathrm{U}$ \\
\hline $541-73-1$ & $1,3-\mathrm{Dich}$ lorobenzene & 0.50 & $\mathrm{U}$ \\
\hline $106-46-7$ & $1,4-D i c h l o r o b e n z e n e$ & 0.50 & $\mathrm{U}$ \\
\hline $95-50-1$ & $1,2-\mathrm{Di}$ chlorobenzene & 0.50 & $\mathrm{U}$ \\
\hline $96-12-8$ & 1,2-Dibromo-3-chloropropane & 0.50 & U \\
\hline $120-82-1$ & $1,2,4$-Trichlorobenzene & 0.50 & $\mathrm{U}$ \\
\hline $87-61-6$ & $1,2,3$-Trichlorobenzene & 0.50 & U \\
\hline
\end{tabular}


Argonne

Environmental Science Division

Argonne National Laboratory

9700 South Cass Avenue, Bldg. 203

Argonne, IL 60439-4843

www.anl.gov

U.S. DEPARTMENT OF

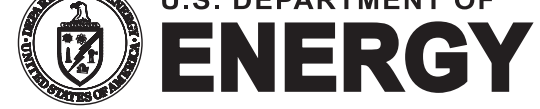

Argonne National Laboratory is a U.S. Department of Energy laboratory managed by UChicago Argonne, LLC 